\title{
Selection of Heat Disposal Methods for a Hanford Nuclear Energy Center
}

by

J. R. Young, L. D. Kannberg,

J. V. Ramsdell, W. H. Rickard, and D. G. Watson

June 1976

Prepared for the Energy Research and Development Administration under Contract E(45-1)-1830 

BNWL - 2003

UC -80

SELECTION OF HEAT DISPOSAL METHODS FOR A HANFORD NUCLEAR ENERGY CENTER

by

J. R. Young

L. D. Kannberg

J. V. Ramsde11

W. H. Rickard

D. G. Watson

June 1976

BATTELLE

PACIFIC NORTHWEST LABORATORIES

RICHLAND, WASHINGTON 99352 


\section{CONTENTS}

FIGURES

TABLES

SUMMARY

INTRODUCTION

HEAT SINK PROBLEM

APPROACH TO THE ANALYSIS

DESCRIPTION OF HANFORD

Hydrology .

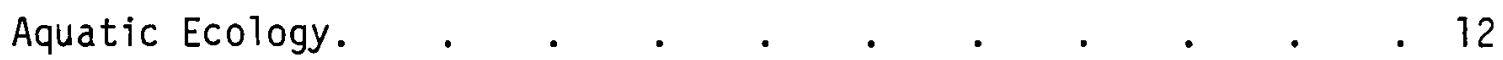

Terrestrial Ecology. . . . . . . . . . 17

Meteorology . . . . . . . . . . . . . . 28

HEAT SINK ALTERNATIVES . . . . . . . . . . 38

Physical Limitations on Cooling Methods. . . . . . 38

Selection of the Cooling Method Cases . . . . . . 44

Description of Heat Sink A7ternatives . . . . . . . 47

REFERENCES . . . . . . . . . . . . . . . 81

APPENDIX A - TERRESTRIAL ECOLOGY SPECIES . . . . . . . . A-1 


\section{FIGURES}

1. HNEC Heat Sink Analysis Procedure . . . . . . . 7

2. Hanford Chinook Salmon Spawning Area . . . . . . 15

3. Hanford Reservation - Energy Research and Development Administration 19

4. Number of Canada Goose Nests on Hanford Reservation Islands 1953-1975. . . . . . . . . . 24

5. Food Web in Terrestrial Habitat . . . . . . . 27

6. Food Web in Waste Pond Habitat . . . . . . 27

7. Daily Climatological Cycles - January . . . . . . . 31

8. Daily Climatological Cycles - June. . . . . . . . 32

9. Wind Roses as a Function of Stability and Wind Speed at HMS Based on Wind at $200 \mathrm{Ft}$ and Air Temperature Stability Defined between

$3 \mathrm{Ft}$ and $200 \mathrm{Ft}$ for 1950-1970. . . . . . . . 35

10. Surface Wind Roses for Various Locations on and Surrounding the Hanford Site. . . . . . . . . . 36

11. Wind Rose for the FFTF Site . . . . . . . . 37

12. Wind Rose for the WNP-2 Site. . . . . . . 37

13. Potential Reactor Cooling Ponds . . . . . . . . 43

14. HNEC Plant Sites . . . . . . . . . . . 46

15. Cost Correlation for Four-Unit Nuclear Power Plant Stations. . 52

16. Salmon Embryonic and Larval Mortalities. . . . . . 59 


\section{$\underline{\text { TABLES }}$}

1. Adult Anadromous Fish Passage, Priest Rapids Dam - 1965-1975 14

2. Fall Chinook Spawning - Hanford .

3. Averages and Extremes of Climatic Elements at Hanford . . . . 29

4. Total Duration and Maximum Persistence of Fog Tabulated in Hours for the Period 1945-1970 . . . . . . . . . . . . 33

5. Unlined HNEC Cooling Ponds . . . . . . . . . . . . . 42

6. Lined HNEC Cooling Ponds . . . . . . . . . . . . . 42

7. HNEC Heat Sink Alternative Analysis Cases - 20 Reactors . 45

8. HNEC Heat Sink Alternative Analysis Cases - 40 Reactors - . 48

9. General Evaluation - HNEC Cooling System Environmental Interaction

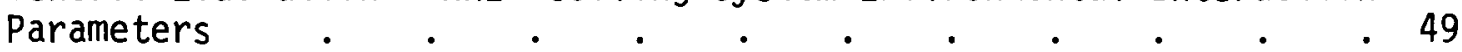

10. Typical Four-Unit Nuclear Power Plant Capital Costs . . . .

11. Power Plant Efficiencies . . . . . . . . . . . . 53

12. Typical 0\&M Costs . . . . . . . . . . . . . . . 54

13. Cooling System Materials . . . . . . . . . . . . 55

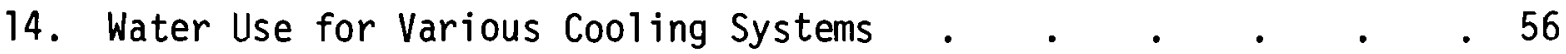

15. Chemical Releases from Wet Towers and Cooling Ponds . . . 56

16. Mortality and Growth of Young Chinook Salmon Reared Under

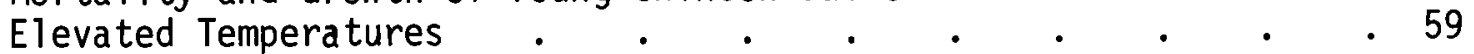

17. Summary of Costs and Benefits Related to Terrestrial Ecology . 66

18. Increased Fog and Visibility of Less than One-Half Mile in the TriCities due to HNEC Using Evaporative Cooling • • • • . $\quad$ • 70

19. Additional Fog in the Tri-Cities for Energy Centers Using Wet-Dry . Mechanical Draft Cooling Towers . . . . . . . . 70

20. Minimum Statistically Significant Increase in Hours of Fog and Visibility Less than One-Half Mile at the $95 \%$ of Significant Level for

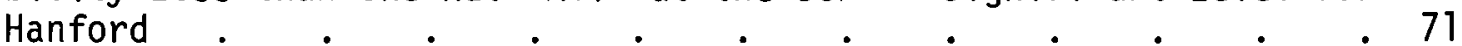

21. Predicted Impact of Development of Nuclear Energy Using Mechanical Draft Cooling Towers on Fog and Visibility in the Tri-Cities. $\quad 72$

22. Summary Comparison of 20 Reactor Heat Sink Alternatives. 74

23. Summary Comparison of 40 Reactor Heat Sink Alternatives. • . 76 


\section{SELECTION OF HEAT DISPOSAL METHODS FOR}

A HANFORD NUCLEAR ENERGY CENTER

J. R. Young, L. D. Kannberg, J. V. Ramsde11

W. H. Rickard and D. G. Watson

\section{SUMMARY}

The possibility of a Hanford Nuclear Energy Center (HNEC) is currently being studied to develop an improved understanding of nuclear energy centers, their advantages and disadvantages, and to identify the research and development necessary to evaluate the nuclear energy center concept. Two cases are considered: one contains 20 nuclear power plants and one contains 40 nuclear power plants. These power plants would be built in clusters of four reactors dispersed throughout the 600 square mile Hanford Reservation in central Washington. Supporting fuel cycle facilities are also included.

Five general heat rejection systems are available for transferring the waste heat from an HNEC to the environment: (1) once-through cooling with Columbia River water, (2) cooling ponds, (3) wet cooling towers, (4) wet-dry cooling towers, and (5) dry cooling towers. These heat rejection systems can be considered relative to a balance of three factors: economics, environmental effects, and resource utilization.

Establishing an appropriate balance among these three factors is complicated by an absence of criteria and by existing or proposed regulations forbidding heat releases to water bodies. Further complications arise from an inadequate knowledge of atmospheric effects of large heat releases. Using data available, heat rejection methods have been selected to illustrate a methodology which might be used in the design of nuclear energy centers. Basically, this approach involves balancing environmental impacts to the atmosphere and to the Columbia River with conservation of resources and costs. 
The most important environmental effects identified to date for HNEC cooling systems are alteration of the Columbia River aquatic life and creation of more ground fog and higher relative humidity as a result of moisture releases into the atmosphere. It should be noted that little capability exists for predicting changes in meteorological events such as icing, rain, and wind. At present only general estimates of the increases of ground fog and humidity increases can be made. Better methods for predicting the meteorological effects of wet cooling tower operation are necessary to assure that excessive adverse effects do not occur. The environmental effects for once-through cooling are mostly aquatic; while for dry-cooled systems they are almost entirely sustained in the atmosphere. The other three systems are combinations of both.

In general, the electricity generation costs for these systems are lowest for once-through cooling, $4 \%$ higher for ponds and wet cooling towers, and 10 to $15 \%$ higher for dry systems. The costs for wet-dry systems are from 5 to $15 \%$ higher in accordance with the portion of the heat transferred by the dry portion of the system.

Results of studies to date have indicated that the "optimum" heat disposal method for an HNEC is a combination of once-through cooling and wet tower cooling. The maximum number of reactors with once-through cooling depends partially on future decisions affecting the minimum river flow, but it appears to be about six reactors for a 20-reactor HNEC and ten reactors for a 40-reactor HNEC based on a Columbia River low flow rate of 54,000 cfs. The remainder of the cooling would be accomplished by tall mechanical draft towers to avoid a significant increase in ground fog formation during the winter months or relative humidity increases in the summer. Although tall mechanical draft towers have not been designed and constructed in the United States, they have been in Europe. Current natural draft towers can be adapted to a mechanical draft operation during sumer low humidity conditions at Hanford.

The impacts due to ground fog formation and humidity increases are essentially independent of the locations of tall cooling towers on the Hanford 
Reservation. Consequently, locations would probably be based on other factors such as aesthetic impacts, proximity to water supply, and economic costs.

Once-through cooling probably will not be permissible during the late surmer in some years because the river temperature at Hanford wil1 be $68^{\circ}$ or above and these temperatures are detrimental to salmon. Scheduling the annual refueling outages for the once-through cooled reactors during that time should avoid economic penalties. The number of reactors with once-through cooling is also a function of the amount of generating capacity which can be shutdown and of the number of outage personnel available.

Addition of heat to the Columbia River from November to June should be beneficial to the growth rate of young salmon and as a result the probability of survival and return for spawning. A comprehensive study is necessary to quantify the benefits and adverse effects of heat additions to the Columbia River during each month of the year and for the expected ranges of river flow rates and temperature.

This aquatic analysis was based on data representative of recent operation of the Columbia River with a minimum permissible release rate of 36,000 cfs at Priest Rapids dam. This minimum flow was established when nine production reactors were operating with once-through cooling at Hanford and the 36,000 cfs flow probably is no longer optimum for current or future conditions. The optimum flow rate for the Hanford reach of the river should be determined for an HNEC case. This optimum flow rate might include increases in both the minimum permissible flow rate and in the minimum daily average flow rate.

Finally, construction of an HNEC would create a long-term commitment of land and material sources to power generation. However, once-through and wet cooling tower systems would not require more resources than would be used in power plants at other sites which probably would have similar cooling systems. 


\section{INTRODUCTION}

Selection of the best method for disposal of the waste heat from a large power generation center requires a comprehensive comparison of the costs and environmental effects. The objective is to identify the heat dissipation method with the minimum total economic and environmental cost.

A 20 reactor HNEC will dissipate about 50,000 MWt of waste heat; a 40 reactor HNEC would release about 100,000 MWt. This is a much larger discharge of heat than has occurred from other concentrated industrial facilities and consequently a special analysis is required to determine the permissibility of such a large heat disposal and the best methods of disposal. It is possible that some methods of disposal will not be permissible because of excessive environmental effects or that the optimum disposal method may include a combination of several methods.

This document presents a preliminary analysis of the HNEC heat disposal problem to determine the best methods for disposal and any obvious 1 imitations on the amount of heat that can be released. The analysis is based, in part, on information presented in the interim conceptual study (Harty, 1975), the heat sink management analysis (Laity, 1975), and the meteorological analysis (Ramsde11, 1976). The information in those documents is repeated here only as needed to assure understanding. 


\section{THE HEAT SINK PROBLEM}

Release of large quantities of heat from a power center can have severe effects on the environment. Normally, large quantities of waste heat are released to nearby water bodies or directly to the atmosphere by use of cooling ponds or wet cooling towers. Cooling water withdrawals and releases to water bodies can severely affect aquatic life through mechanical abrasion in pumps and heat exchange systems or changes in water temperatures or chemical composition. Construction of large cooling ponds can heavily impact terrestrial 1 ife by reduction of habitat. Transfer of the heat to the atmosphere either from ponds or from cooling towers may increase fog or modify nearby habitats as a result of icing in the winter. Release of blowdown streams containing high concentrations of dissolved salts, biocides, and corrosion inhibitors also may adversely affect aquatic life in nearby water bodies.

Releases of heat from an HNEC must comply with the provisions of Public Law 92-500 which requires by 1983 (1) the application of the best available technology economically achievable and (2) the elimination of discharges when technologically and economically achievable. However, in the case of thermal discharges, a release is permissible whenever it can be demonstrated that the release will ensure the protection and propagation of a balanced, indigenous population of shellfish, fish, and wildlife in and on that body of water.

The overall purpose of a heat sirik evaluation is to identify the heat disposition methods with the best balance among economics, environmental impacts, and resource utilization. The general approach in this evaluation was to define the combination of cooling systems with the lowest total economic, environmental costs and resources utilization. The specific criteria were: (1) The economic costs should be as low as possible; (2) There should be an acceptable level of environmental effects (and preferably no significant adverse effects); and (3) Resource utilization should be as low as practicable, particularly for scarce resources. 
In general, there are 24 environmental interaction parameters to consider to determine the best design for the heat dissipation facilities for a power system. Each of these parameters must be evaluated for each of the alternative heat dissipation methods, and then the sum of the effects of all parameters for each method must be compared to the sums for the other alternatives to determine the most desirable alternative.

Numerous methods have been developed for reducing the environmental effects of heat dissipation systems. However, action to reduce an adverse effect usually increases economic costs and may create new environmental problems. Selection of the best design for the best dissipation system requires a subjective balance between the economic, environmental costs, and resource utilization. 


\section{APPROACH TO THE ANALYSIS}

The heat dissipation methods tentatively selected for the HNEC were determined by use of the standard environmental assessment cost-benefit analys is procedures generally used during preparation of environmental reports and statements. The general procedure as adapted to this analys is is presented schematically in Figure 1.

DEFINE STUDY OBJECTIVE

DESCRI BE APPROPRIATE HANFORD CHARACTERISTICS

IDENTIFY POTENTIAL HEAT DISSIPATION METHODS

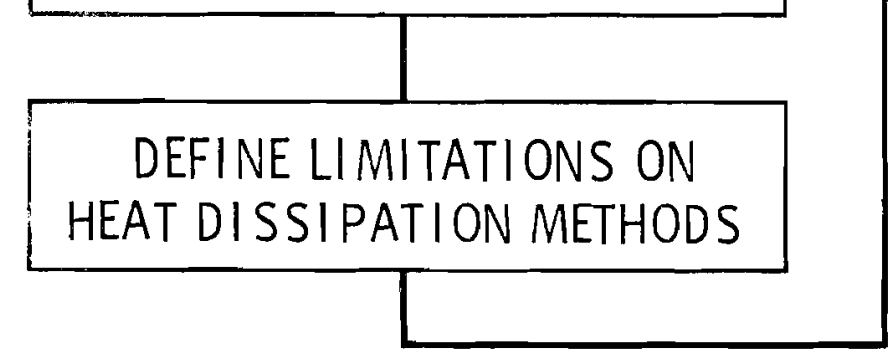

DEFINE ALTERNATIVE HEAT DISSIPATION CASES

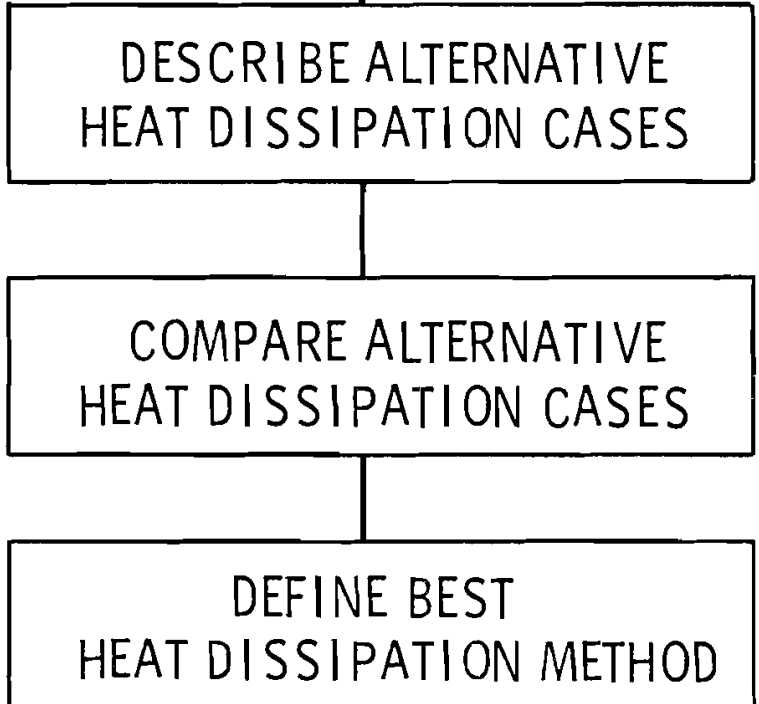

FIGURE 1: HNEC Heat Sink Analys is Procedure 
First, the objective of the analysis was defined as: Determine the best disposal method for the waste heat from either 20 or 40 power plants built at Hanford as described in BNWL-B-458 (Harty, 1975). Then, a detailed description was prepared of the Hanford Reservation physical characteristics, in addition to a general description of the physical and social characteristics of the surrounding territory. Emphasis was placed on those characteristics expected to be significantly affected by the waste heat disposal problem. The physical characteristics of the Hanford Reservation indicated five possible methods for heat disposal:

1. Once-through cooling with Columbia River water,

2. Cooling ponds,

3. Mechanical draft wet cooling towers,

4. Mechanical draft wet-dry cooling towers, and

5. Dry cooling towers.

Twenty alternative heat dissipation cases were selected for the initial alternative analysis. These cases defined the extreme cases for the five possible heat dissipation methods (e.g., all wet cooling towers, all dry towers, etc.) and also the combinations of heat dissipation methods that represented minimum impact conditions (minimum economic costs, minimum fog formation for wet systems, etc.). They were then described and analyzed to determine the economic and environmental costs. Comparison of the cases then defined the best heat dissipation methods.

Al though dry cooling has not been demonstrated on a large scale, it was assumed that it would be a reliable method soon enough to be used for most of the HNEC power plants. Natural draft wet cooling towers are uneconomical for Hanford in comparison to mechanical draft towers because of the large increase in condenser cooling water temperature that would be necessary during the summer low-humidity, high-temperature meteorological conditions. The environmental limitations on the use of each of the five cooling methods then were estimated. An example of such a limitation is the maximum pernissible heat releases to the Columbia River in accordance with the applicable water quality standards. 
An important part of this preliminary heat sink evaluation was to identify the available technology necessary for the evaluation and the need for new technology. Because of limitations in the ability to predict meteorological and aquatic biology effects, the estimations of environmental effects may change as additional data and analytical capability become available. 


\section{DESCRIPTION OF HANFORD}

Extensive descriptions of the Hanford Reservation have been documented as a result of the ERDA facility operations (ERDA, 1975) and preparation of environmental reports for the Washington Public Power Supply System power reactors (USAEC, 1972). A summary of these characteristics was presented in the interim conceptual report for the HNEC (Harty, 1975).

The pertinent site characteristics for a heat sink evaluation are the hydrology, ecology, and meteorology. Hydrology is important because of the need for large quantities of water either as a heat sink or as a source of water evaporated during transfer of heat to the atmosphere. The ecology is important because use of water and land can have significant effects on life forms and on human recreational activities. Meteorology is important because release of large quantities of heat and moisture may affect human activities through creation of fog, increased humidity, and precipitation. These characteristics for the Hanford Reservation are summarized below.

HYDROLOGY

The only reliable source of the large quantities of water needed for wet cooling systems for large power plants is the Columbia River. Insufficient ground water is available, and all water in the Yakima River is allocated for other purposes during the low flow summer months.

The Columbia River in and near the Hanford Reservation is the last free-flowing stretch within the United States; the remainder is made up of a series of impoundments behind the 11 hydroelectric dams in the river. Average, maximum, and minimum flows are about 120,000,690,000, and 36,000 cfs, respectively. Since 1960, the minimum average seven-day running mean flow rate has exceeded 54,000 cfs at all times. Peak flow rates occur in late spring and early summer. During late summer, fall and winter daily fluctuations in discharge may range from 36,000 to 160,000 cfs due to flow regulation by the upstream Priest Rapids Dam. This variation in flow can cause 
changes in elevation of 10 feet near the upstream part of the Hanford Reservation and 5 feet in the lower reaches. Current velocities vary from less than 3 to over 10 fps.

The flow rate of the Columbia River during low flow periods is determined primarily by the amount of water released from upstream dams. These dams have over 30,000,000 acre-feet of storage capacity corresponding to an average flow of $60,000 \mathrm{cfs}$ during the low-flow period from August to March of each year.

Monthly average river temperatures range from 1.5 to $20.2^{\circ} \mathrm{C}$, with maximums occurring in August and September, the minimums in February. The naturally occurring temperature changes in the river between Priest Rapids and Richland range from $-0.8^{\circ} \mathrm{C}$ in the winter to $+0.8^{\circ} \mathrm{C}$ in the summer. River bottom substrates are typically sand, rock, and gravel. Cobbles and boulders are present in many areas and fine silt and sand are found in the slack waters. Water quality of the river is good with dissolved oxygen usually greater than $10 \mathrm{ppm}$, pH 6.5 to 8.5 and dissolved solids of $154 \mathrm{ppm}$ or less (ERDA, 1975).

Less than ten percent of the Columbia River flow at Hanford is used for downstream consumption. In addition, the major use, irrigation, occurs primarily during the summer high flow period when the river flow is generally much higher than $50,000 \mathrm{cfs}$. As a result, consumption of up to 2,000 cfs at Hanford should be possible without interference with downstream consumption.

Cooling facilities must be operated at Hanford such that there is no significant effect on radionuclides currently present in the ground or in the waste storage tanks and burial grounds. Generally, this means that (1) there cannot be a significant rise in the water table evaluation underneath the ERDA production areas and burial sites, and (2) the flow rate toward the Columbia River of the groundwater containing tritium cannot be increased. Creation of a barrier to flow of groundwater containing tritium into the river would probably be considered favorabie. 
Since there is no Hanford generated tritium in groundwater north of the Columbia River, effects of water releases on that groundwater are of less concern. However, liquefaction and subsidence of soils always must be considered in siting large structures.

\section{AQUATIC ECOLOGY}

The effects on the aquatic environment that potentially may arise from the establishment of cooling systems for an HNEC are mainly those associated with the withdrawal of Columbia River water for power station condenser cooling and processing, and the discharge of station effluents to the river. These include loss of fish and other aquatic organisms from the following:

- Impingement on the water intake screens causing physical damage from the impact or subsequent screen cleaning operations.

- Passage through the station cooling system. Impacts may range from the death or injury of aquatic organisms due to thermal, chemical and mechanical stress in once-through cooling systems to the removal of river plants and animals in the make-up water of closed-cycle cooling systems.

- Discharge of toxic chemicals and heat to the river that may alter metabolic rates, reproductive cycles, behavior, disease resistance and food base, or cause mortalities as a result of rapid changes in temperature, i.e., heat and cold shock.

The creation of new surface waters (cooling ponds) may be conducive to the growth of nuisance algae and fish disease organisms. Benefits may also be obtained, however, through the development of new areas for sport fishing or the production of human and animal food through aquaculture.

Many of the physical, chemical and biological characteristics of the Columbia River are summarized in the document WASH-1538 (ERDA, 1975). The primary biological systems of concern are the phytoplankton, zooplankters, benthic organisms, and fish. (Appendix A lists the scientific names for the species of interest.) 
The phytoplankton originates in the impoundments behind the upstream dams and from the attached algae on the river bottom. Diatoms are the dominant algal group. Biomass of net phytoplankton range from a maximum of about $2.0 \mathrm{~g} \mathrm{dry} \mathrm{wt} / \mathrm{m}^{3}$ in May to less than $0.1 \mathrm{~g} \mathrm{dry} \mathrm{wt} / \mathrm{m}^{3}$ in winter.

Cladocerans and copepods are the dominant zooplankters. Numbers of zooplankters in the main river channel average $600 / \mathrm{m}^{3}$ with maximums of $12,000 / \mathrm{m}^{3}$ in summer to less than $30 / \mathrm{m}^{3}$ in winter (Page, 1976). Both phytoplankton and zooplankton are nearly uniformly distributed throughout the river cross-section.

The principal benthic organisms include insect larvae, sponge, molluscs, flatworms, leeches, crayfish and 01 igochaetes (ERDA, 1975). Sponge, caddisfly larvae and chironomid larvae make up the bulk of the benthic organisms (Page, 1976). Greatest abundance is in the near shore areas. Maximum biomass ranges from 16 to $38 \mathrm{~g} / \mathrm{m}^{2}$ in the most productive riffle areas (USAEC, 1972).

There are over 40 species of fish in the Hanford section of the Columbia River (ERDA, 1975). About half of these are of no recognized direct value to man. Sturgeon, whitefish, catfish, perch, bass, sunfish and crappie are permanent residents of the area and provide recreational fishing; anadromous salmon, steelhead trout and shad are economically important to both commercial and sport fisheries.

The latter group use the local reach of the river as a spawning and rearing area and as a migration route to and from upstream spawning grounds. The extent to which the local section of river is used by adult anadromous upstream migrants is given in Table 1, showing the passage of fish over Priest Rapids immediately upstream from the Hanford Reservation. Although chinook salmon and steelhead trout move up the Columbia during all months of the year, the greatest numbers are present during the period from April through November.

The Hanford Section of the Columbia is one of the last main-stream river areas used for spawning by fall chinook salmon. The major sections of the 
TABLE 1: Adult Anadromous Fish Passage, Priest Rapids Dam - 1965-1975

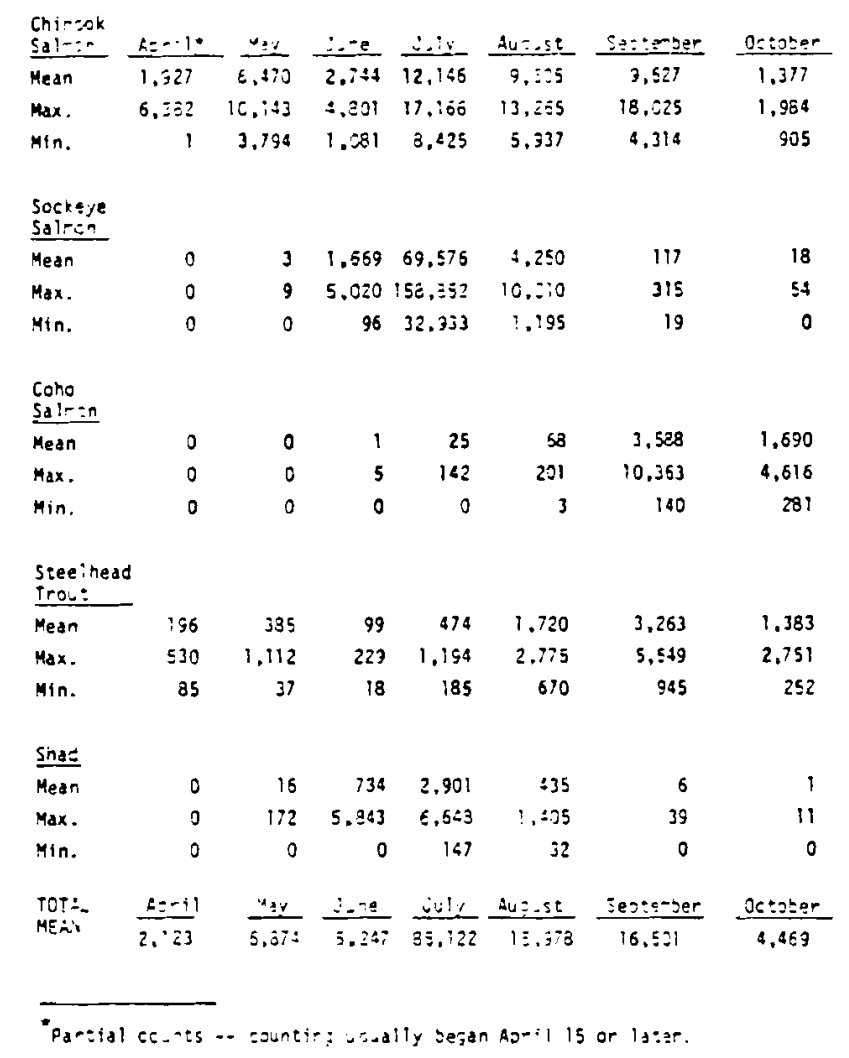

river used for spawning are shown in Figure 2. Most of the spawning takes place near the river is ?ands in depths of approximately 3 to 12 feet in rapidly flowing water. Spawning begins about the middle of October and is concluded by the middle of November. Egg incubation and larval fish emergence from the redds (nests) in the river bottom takes place from February through April. The numbers of fall chinook salmon redds and estimates of the local spawning population are given in Table 2. Although there is considerable variability in the Hanford chinook spawning population, it represents a significant part of the adult fall chinook in the river, $15 \%$ of the escapement over Bonneville Dam and about 30\% of the fall chinook reaching the middle Columbia River (Watson, 1970).

Average annual steelhead trout spawning population estimates near Hanford for the years 1962-1971 are about 10,000 fish (Watson, 1973) and the 


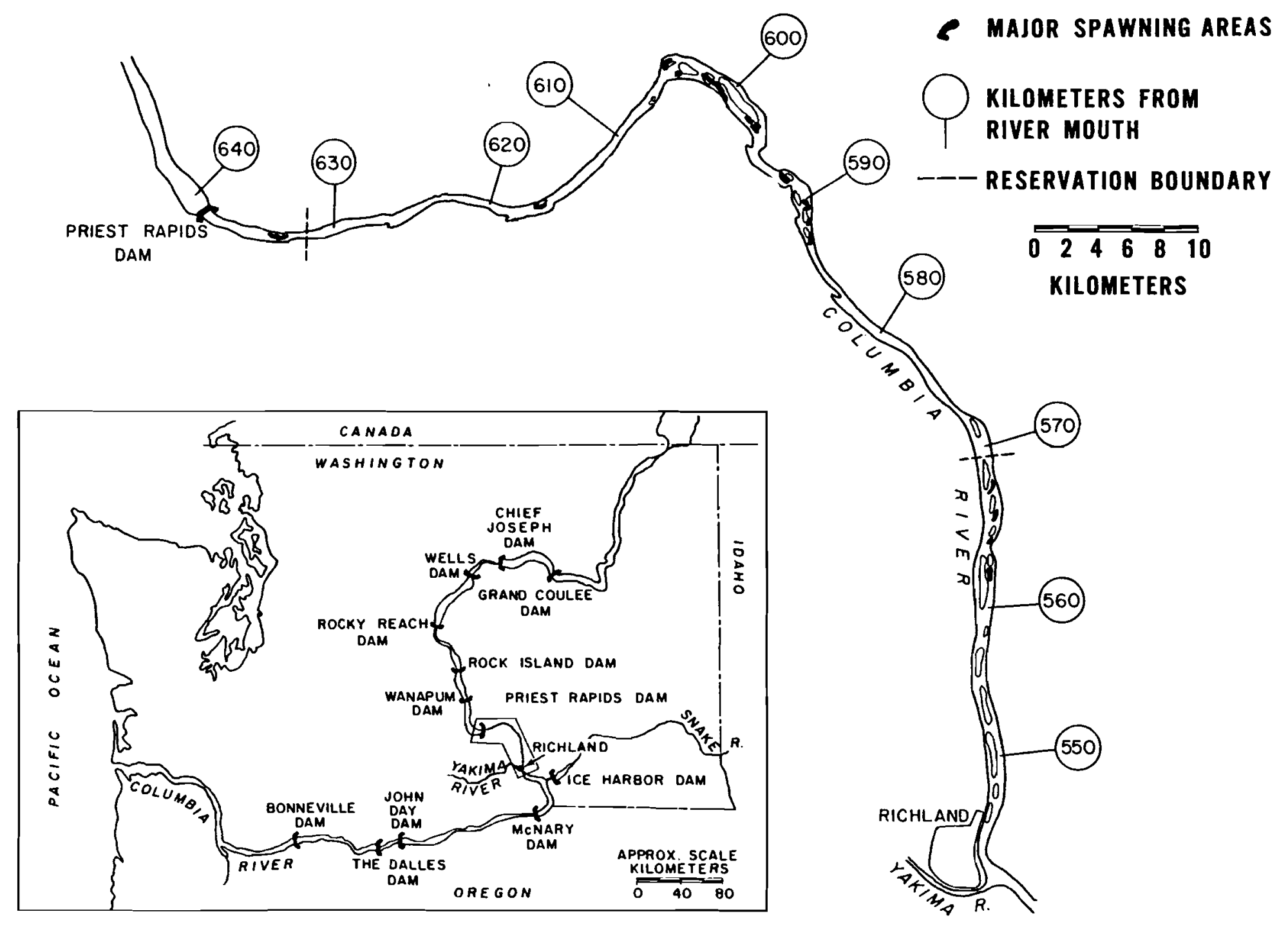

FIGURE 2: Hanford Chinook Salmon Spawning Area 
TABLE 2: Fall Chinook Spawning - Hanford

Nunber of Redds (nests)*

River Kilometer

\begin{tabular}{|c|c|c|c|c|c|c|c|c|c|c|}
\hline & Year & $560-570$ & $586-592$ & 597 & $600-608$ & 618 & 633 & Other & Total & $\begin{array}{l}\text { Estimated } \\
\text { No. Salmon }\end{array}$ \\
\hline & 1947 & 0 & 15 & 25 & 10 & 0 & 75 & 115 & 240 & 1680 \\
\hline & 1948 & 120 & 330 & 38 & 219 & 0 & 25 & 53 & 785 & 5500 \\
\hline & 1949 & 45 & 50 & 6 & 195 & 0 & 1 & 33 & 330 & 2310 \\
\hline & 1950 & 24 & 43 & 38 & 151 & 3 & 46 & 11 & 316 & 2210 \\
\hline & 1951 & 5 & 10 & 45 & 151 & 5 & 95 & 3 & 314 & 2200 \\
\hline & 1952 & 73 & 101 & 40 & 221 & 3 & 78 & 23 & 539 & 3770 \\
\hline & 1953 & 7 & 5 & 16 & 38 & 0 & 83 & 0 & 149 & 1040 \\
\hline & 1954 & 4 & 5 & 8 & 127 & 0 & 6 & 7 & 157 & 1100 \\
\hline & 1955 & 0 & 12 & 0 & 47 & 0 & 4 & 1 & 64 & 450 \\
\hline & 1956 & 0 & 3 & 7 & 59 & 0 & 17 & 6 & 92 & 640 \\
\hline & 1951 & 27 & 173 & 55 & 440 & 43 & .132 & 2 & 872 & 6100 \\
\hline \multirow{18}{*}{$\vec{\sigma}$} & 1958 & 49 & 249 & 133 & 520 & 192 & 258 & 83 & 1485 & 10400 \\
\hline & 1959 & 1 & 0 & 36 & 101 & 32 & 111 & 0 & 281 & 1970 \\
\hline & 1960 & 0 & 31 & 22 & 99 & 38 & 105 & 0 & 295 & 2070 \\
\hline & 1961 & 0 & 27 & 43 & 201 & 23 & 640 & 4 & 939 & 6570 \\
\hline & 1962 & 6 & 195 & 66 & 456 & 1 & 635 & 2 & 1261 & 8830 \\
\hline & 1963 & 0 & 283 & 127 & 506 & 14 & 370 & 3 & 1303 & 9120 \\
\hline & 1964 & 5 & 163 & וווו & 510 & 37 & 624 & 27 & 1477 & 10300 \\
\hline & 1965 & 4 & 262 & 211 & 588 & 54 & 659 & 11 & 1789 & 12500 \\
\hline & 1966 & 10 & 279 & 267 & 1206 & 37 & 1300 & 2 & 3101 & 21700 \\
\hline & 1967 & 28 & 388 & 273 & 1192 & 17 & 1340 & 29 & 3267 & 22900 \\
\hline & 1968 & 117 & 595 & 188 & 1069 & 52 & 1520 & 39 & 3560 & 24900 \\
\hline & 1969 & 265 & 820 & 427 & 1446 & 50 & 1500 & 0 & 4508 & 31600 \\
\hline & 1970 & 107 & 615 & 302 & 1180 & 72 & 1528 & 9 & 3813 & 26700 \\
\hline & 1971 & 182 & 560 & 416 & 1071 & 10 & 1361 & 0 & 3600 & 25200 \\
\hline & 1972 & 88 & 247 & 147 & 259 & 4 & 131 & 0 & 876 & 6130 \\
\hline & 1973 & 137 & 458 & 179 & 1273 & 62 & 856 & 0 & 2965 & 20800 \\
\hline & 1974 & 164 & 156 & 49 & 238 & 5 & 173 & 3 & 728 & 5100 \\
\hline & 1975 & 95 & 458 & 291 & 752 & 91 & 995 & 1 & 2683 & 18780 \\
\hline
\end{tabular}


spawning areas are thought to be generally similar to those used by the fall chinook salmon. Steelhead support a fairly intensive sport fishery between Ringold and Richland.

The juvenile chinook salmon pass through the Hanford section of the Columbia from March through July (Mains and Smith, 1964), although there is some evidence that the young of populations spawning upstream of Priest Rapids may continue through August (Park, 1969). There is a tendency for the young salmon to migrate downstream near shore and near the surface of the river (Mains and Smith, 1964). In addition to the salmon produced in the river, young are released to the river from the Washington Department of Fisheries artificial spawning channel at Priest Rapids Dam and from the rearing facility at Ringold. Steelhead young are also reared and released to the river at Ringold by the Washington Department of Game.

Food of the young salmon migrating through the Hanford section of the river consists almost entirely of aquatic insects $(96 \%$ of diet), most of which originate from the river benthos (Becker, 1970).

\section{TERRESTRIAL ECOLOGY}

The effects on the terrestrial environment that potentially would result from establishment of cooling systems for nuclear power stations at hanford are mainly those associated with occupancy of land by cooling system facilities. This land occupancy would reduce the total habitat for terrestrial life. The net reduction in inhabitants would depend on the type of 1 and occupied and the alteration of surrounding lands as a result of moisture releases from the cooling facilities. Releases of moisture could increase total populations by creation of additional habitat and watering sites which would more than compensate for the loss of land occupied by the cooling facilities. However, the new populations would consist of different species than the original inhabitants.

\section{Natural Vegetation}

The natural vegetation of the Hanford Reservation is classified as shrub-steppe (Daubenmire, 1970). The shrub component is characteristically 
dominated by big sagebrush and the understory is composed of many herbaceous species, especially grasses, the most common of which are bluebunch wheatgrass, Sandberg bluegrass, and cheatgrass.

The undisturbed vegetation mosaic can be subdivided into three major vegetation types on the basis of shrub species in the overstory and the dominant herbaceous species in the understory. The big sagebrush/bluebunch wheatgrass vegetation type is confined to the Rattlesnake Hills and is entirely located within the boundaries of the Arid Lands Ecology Reserve (ALE). The big sagebrush/antelope bitterbrush/cheatgrass vegetation type occupies a triangular shaped area extending from the $100 \mathrm{~F}$ reactor area to the Horn Rapids bend of the Yakima River (Figure 3). The vegetation type occupying the remainder of the Hanford Reservation is classified as the big sagebrush/ cheatgrass.

The three vegetation types of most concern to the construction and operation of the facilities associated with an HNEC are the big sagebrushantelope bitterbrush/cheatgrass and big sagebrush/cheatgrass types, and the riparian plant communities associated with the Columbia River shoreline and islands. Although these latter communities occupy small acreages as compared to other communities, they are especially important to wildlife populations of mule deer, Chinese ring-necked pheasants, California quail, and to nesting populations of the Canada goose.

Special Biological Habitats

Many kinds of special habitats are recognized. One of these is an extensive area of sand dunes located north and east of the Washington Public Power Supply System's Hanford 1, 2, and 4 power stations. Typical of others are a geological formation of knob and kettle topography located near the $\mathrm{N}$-Reactor (Figure 3); a series of tall, steep-walled bluffs along the eastern shore of the Columbia River known as "White Bluffs"; and a series of basaltic cliffs associated with Gable Mountain and Gable Butte, centrally located in the reservation area.

White Bluffs: The cliff faces of these bluffs provide ancestral nesting sites for thousands of cliff swallows. These birds are present for a 


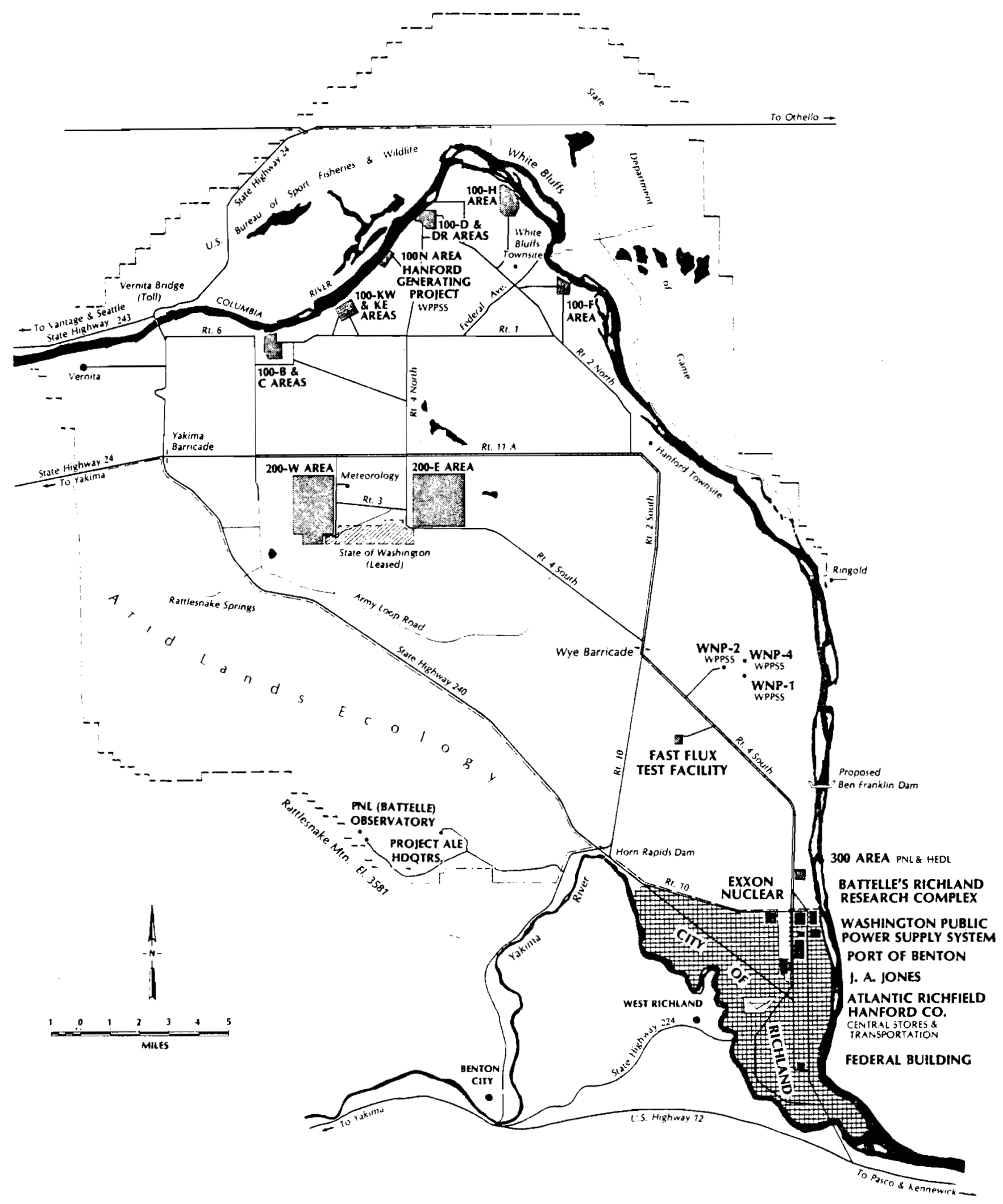

FIGURE 3: Hanford Reservation 
few weeks in summer, raise their young, then migrate to neotropical regions with the onset of autumn weather. The birds forage on adult flying insects that are produced in the aquatic environment of the Columbia River. Cracks in the bluff face provide nesting locations for starlings and feral rock doves. The cliff faces are erodible and provide only a few ledges deep enough to provide nest sites for prairie falcons. If nuclear facilities are not built above these cliffs, there is no reason to expect that the construction and operation of nuclear energy facilities at Hanford would deleteriously affect the bird populations dependent upon the White Bluffs as nesting habitat. However, construction of facilities above the cliffs could result in water releases to the ground and destruction of the nesting sites by landslides.

Gable Mountain and Gable Butte: The basalt cliffs are remote and inaccessible and provide ledges which are used for nesting by the prairie falcon (at least one active nest is known from Gable Butte), red-tailed hawk, and great horned owl. The talus slopes provide habitat for rock wrens and canyon wrens. There is no reason to expect that the construction and operation of a nuclear energy facility at Hanford would deleteriously affect the breeding bird population dependent upon Gable Mountain and Gable Butte as nesting habitat.

Man-made Habitats: Deciduous trees planted for shade and/or fruit years ago have survived without human attention for periods as long as 35 years. Today, these trees provide nest sites for certain birds that otherwise could not be associated with the treeless vegetation of the Hanford Reservation, i.e., Swainson's hawk, red-tailed hawk, sparrow hawk, great-horned owl, raven, magpie, great blue heron, and black-crowned night heron. Many of the trees now supporting nests are senescent. Because these trees do not establish young trees from seeds, it is oniy a matter of time until they disappear from the Reservation. With the demise of trees, birds will have to seek nest sites elsewhere. The planting of trees around nuclear energy facilities can be expected to enhance the nesting potential of tree-nesting avifauna.

Aqueous effluents from chemical processing facilities and irrigation canals have created ponds of various ages on the Hanford Reservation. Other 
ponds located east of the Columbia River have been created from seepage and waste waters from irrigation canals on the Wahluke slope. These ponds are less than ten years old and are expected to persist for an indefinite period of time. The vegetation associated with pond and shoreline environments provide habitat attractive to a wide spectrum of birds (Fitzner and Rickard, 1975). The biological problems and benefits associated with open ponds can be expected if these are contemplated for HNEC facilities.

Another kind of man-made habitat present on the Hanford Reservation is abandoned agricultural fields. For the most part, these are located near the Columbia River adjacent to the former townsites of Hanford and White Bluffs. After 30 years of abandonment, these fields support self-sustaining swards of annual plants, especially cheatgrass. These annual swards have resisted natural invasion by native perennial species for more than 30 years.

Sand Dunes: Sand dunes occupy several thousand acres of land on the western shore of the Columbia River in Benton County. For the most part, the dunes are not occupied by plants; however, a few species can become established on the nutrient-deficient and wind-mobile dune sands (Langham, 1970). The dune area is almost inaccessible to conventional vehicles and provides a sanctuary area for mule deer during the spring fawning season (Hedlund et a1., 1975).

River Islands: The islands in the Columbia River located between the northern boundary of the Hanford Reservation and the City of Richland provide nesting habitat for a smal1 population of resident Canada geese. The nesting history of this population has been studied (Hanson and Eberhardt, 1971). The islands provide critical habitat necessary for the sustainment of the Canada goose population.

Knob and Kettles: Unusual topography occurs on the western bank of the Columbia River near the $\mathrm{N}$-Reactor. The origin of knob and kettle topography is believed to be a result of glacio-fluvial action. A description of the vegetation and animal populations of this area has been recorded (Rickard, 1975, and Hediund et al., 1975). 
Rock Outcrop: Rock outcrop plant communities are particularly well deve1oped along the crest of the Rattlesnake Hills located within the Arid Lands Ecology (ALE) Reserve. The communities occupy relatively little acreage but support plants that are not found elsewhere on the Hanford Reservation. Two species found in the Rattlesnake Hills are on the Smithsonian list of endangered species, Balsamorhiza rosea and Eriogonum thymoides. Because most of the habitat supporting these plants is protected from intrusion by the ALE Reserve, the construction and operation of HNEC facilities would not be expected to deleteriously affect the status of these communities.

Gravel Bars: Gravel bars are characteristically found along fast-flowing streams and rivers. The coarse rooting substrate provided by gravel and cobbles in addition to inundation by seasonal flooding makes gravel bars difficult habitats for plant colonization. Nevertheless, some specialized plant species can invade water-washed gravel bars and maintain populations for years. Gravel bars along the Columbia River support many types of herbaceous plants. However, there have been no ecologically descriptive studies made of these communities.

Primary Productivity

Shrub-steppe plant communities are more productive than desert plant communities but less so than certain grass and forest communities (Rodin and Bazilovitch, 1975). Studies conducted on the Arid Lands Ecology Reserve in stands of the sagebrush-bluebunch wheatgrass in conjunction with the United States' contribution to the International Biological Program Grassland Biome project show that best annual production is less than $100 \mathrm{~g} / \mathrm{m}^{2} /$ year.

\section{Wildlife Populations}

\section{Mule Deer}

The mule deer is the only big game mammal on the Hanford Reservation. Although these animals roam over the entire Reservation, the major population concentration is along the Columbia River. The deer population here is at least one hundred animals (Hedlund, 1975). Critical fawning areas are 
the islands in the Columbia River and the remote portions of the sand dunes. Fawn tagging has been conducted for seven consecutive years. Animals tagged on the Hanford Reservation have been killed by hunters 70 miles from their initial capture points (Hedlund, 1975).

The construction of HNEC facilities can affect the daily and seasonal patterns of movement of mule deer on the Hanford Reservation. Tall, chainlink fences are effective barriers to mule deer movements as are wide, deep concrete-walled irrigation canals. Some deer mortality can be expected from increased automobile traffic.

A1though hunting has not been permitted on the Hanford Reservation, animals produced there provide game for hunters on bordering lands. The main human value of the mule deer here on the Reservation is the esthetic appeal of sighting these animals wild in their natural habitat.

\section{Canada Goose}

Nesting populations of Canada geese have been studied for many years (Hanson and Eberhardt, 1971). Over the years of study, the number of nests has declined (Figure 4). The decline is attributed to predation, changing vegetation structure on the islands, and human interference created by opening the lower section of the Hanford Reservation to public recreation.

Migrant flocks of Canada geese have historically used the Columbia River as a resting stop during spring and fall migration. These geese make foraging flights to nearby agricultural fields and rangelands that support newly germinated stands of cheatgrass. Department of Interior Wildlife refuges located in Franklin and Walla Walla Counties also attract migrant Canada geese as we11 as other waterfowl species.

Upland Game Birds

Chukar partridges are important game birds in steppe vegetation of eastern Washington. These birds were introduced to North America from Eurasia to provide bird hunting for sportsmen. They are especially plentiful in the Rattlesnake Hills and Saddle Mountains, although there are also a few coveys in the Gable Mountain and Gable Butte areas. 


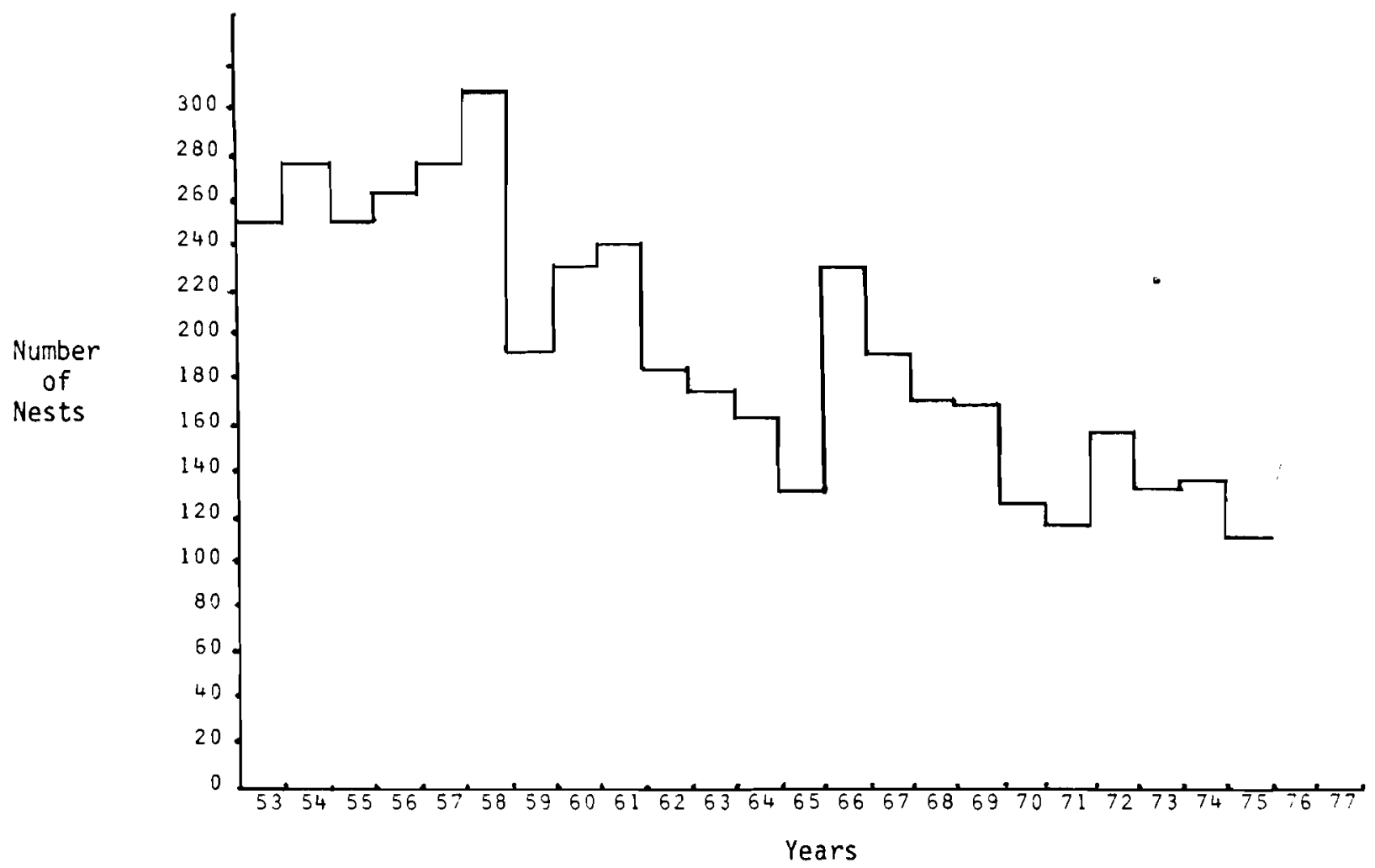

FIGURE 4: Number of Canada Goose Nests on Hanford Reservation Islands 1953-1975

California quail and Chinese ring-necked pheasants are mostly confined to the deciduous shrub vegetation associated with the shoreline of the Columbia River. Like the chukar partridge, the pheasant is an introduced species. The California quail was introduced to washington from its native range in California.

The sagegrouse is scarce on the Hanford Reservation. A few birds are found on the ALE Reserve where they are protected from hunting.

The mourning dove is a common, summer resident of the Hanford Reservation, nesting wherever water and weed seeds are available. Birds produced on the Reservation leave in the fall and migrate south. Hunters harvest large numbers of doves during this migration period. 
Sma 11 Game Mamma 1s

The important small game mammals of the Hanford Reservation are cottontail rabbits and black-tailed hares. Hares are distributed throughout the steppe vegetation areas while cottontails are found in local concentrations where food and cover are available.

Black-tailed hares were studied as biological indicators of radioiodine in the environment (Hanson, 1962) and as a biological agent for the dispersal of radionuclides in waste management areas (0'Farrell and Gilbert, 1975).

\section{Predatory Mamma $1 \mathrm{~s}$}

The most important mammalian predators on the Hanford Reservation are the coyote and badger. Little is known about the population dynamics of either; however, recent studies using radiotracking techniques show that coyotes can wander many miles.

Bobcats are present on the Reservation but in low numbers. Other predators are the raccoon, skunk, mink, and weasel. These animals are mostly confined to riparian habitats associated with the Columbia River.

Other Mamma 7s

Muskrats and beaver are present in the Columbia River. Muskrats occur in ponds and ditches elsewhere on the Reservation (Rickard et a1., 1975). The most abundant small mammals are rodents, especially the Great Basin pocket mouse, deer mouse, and the Townsend ground squirrel. The population dynamics of the pocket mouse has received the most study (O'Farrell et al., 1975).

Consumer Productivity

Shrub-steppe vegetation historically did not support large herbivores such as bison and antelope. Instead, sma 11 mammals like the Great Basin pocket mouse and the Townsend ground squirrel are the abundant vertebrate herbivores. Population dynamics of pocket mice have been intensively studied (0'Farre11 et al., 1975; Schreiber, 1974). 
The most direct use of steppe vegetation as a food source to man is cattle grazing. Cattle grazing studies on the ALE Reserve show that one acre of sagebrush-bluebunch wheatgrass pasture can produce only about 20 pounds of cattle liveweight per year without damaging future community production.

\section{Wildlife as a Recreational Resource}

Tagging studies of mule deer show that mule deer produced as fawns on the Hanford Reservation are killed by hunters when they leave the reservation (Hedlund, 1975). Several hundred Canada geese are produced each year from the nesting populations and some of these are killed as they leave the protection of the reservation (Hanson and Eberhardt, 1970). Chukar partridges regularly nest and produce young on the ALE Reserve. Some of these are probably killed on the Washington State Department's Rattlesnake Hills Wildlife Area and private lands adjoining the reserve.

Coyotes are a permanent constituent of the wildlife resource of the Hanford Reservation and young are reared on the Reservation. Some of these animals probably leave the Reservation where they are available for predator hunting or they may also be regarded as pests by livestock raisers.

The Hanford Reservation serves as a nesting refuge for birds that are diminished throughout the western states as their ancestral habitats are usurped by man-imposed land uses. These birds - burrowing owl, long-billed curlew, great horned owl, Swainson's hawk, red-tailed hawk, and prarie falcon - all contribute to enjoyment of people who like to watch birds.

Food Webs

Diagrammatic representations of food webs in typical terrestrial and waste pond habitats are shown in Figures 5 and 6. 


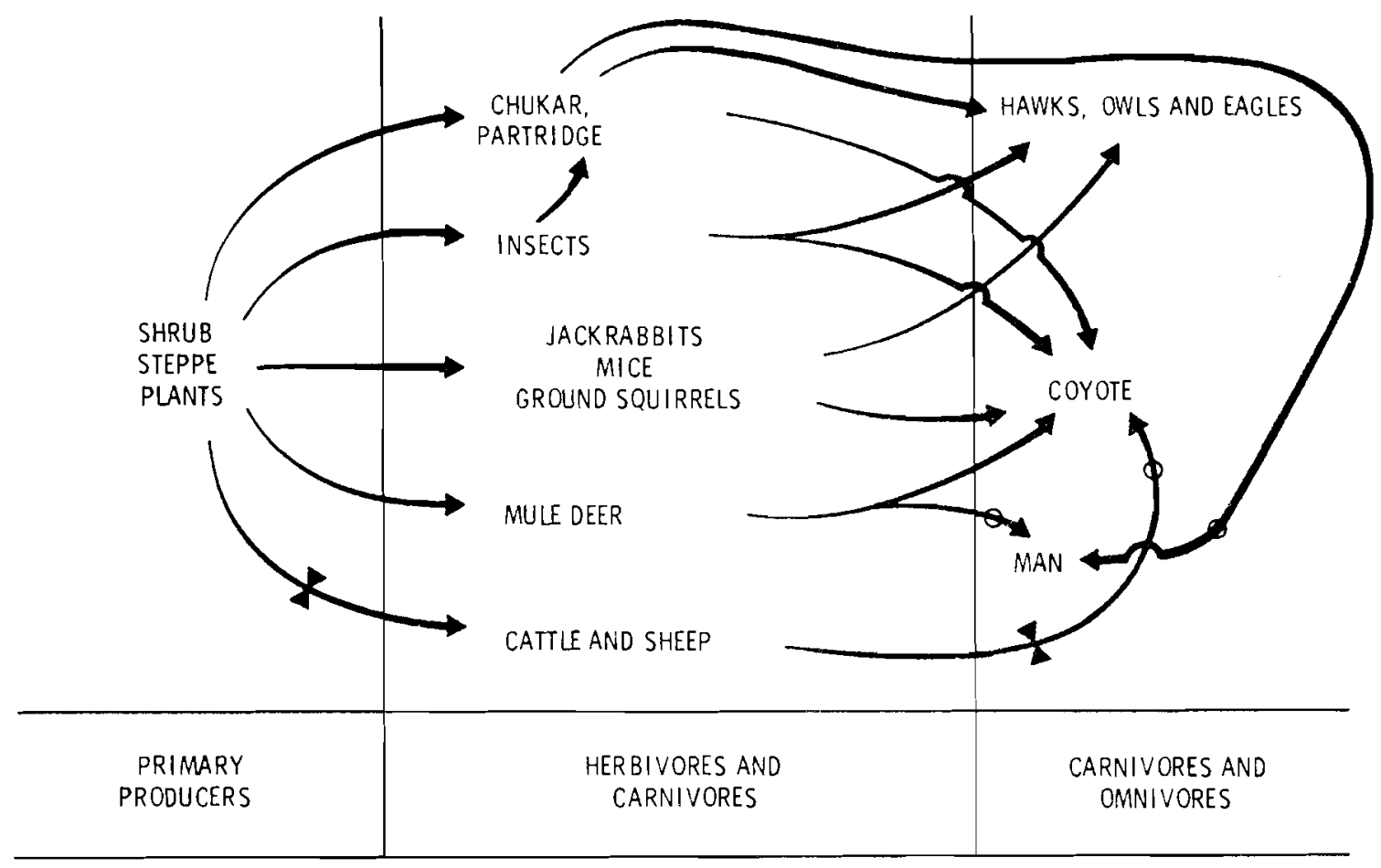

Z CONTROLLED MANAGEMENT

— SEMI-CONTROLLED MANAGEMENT

FIGURE 5: Food Web in Terrestrial Habitat

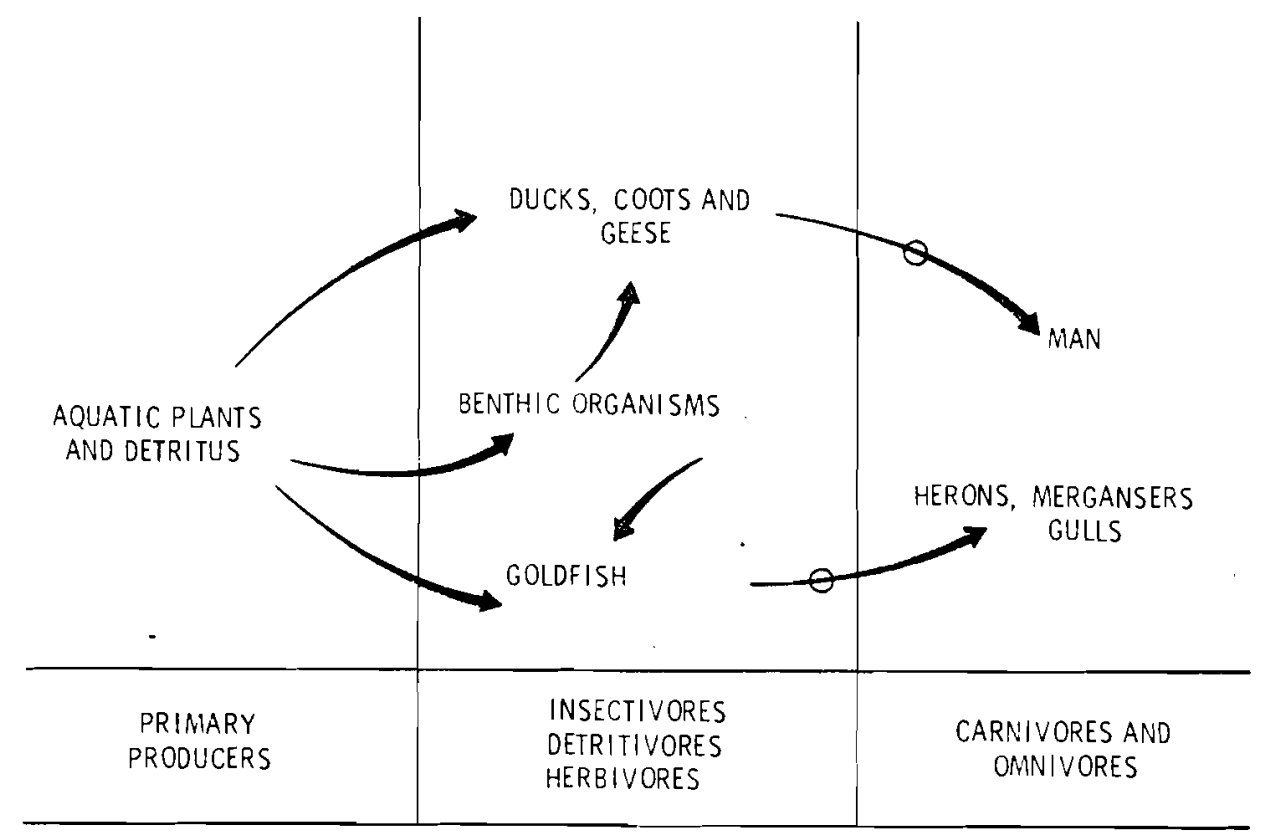

- SEMI-CONTROLLED MANAGEMENT

FIGURE 6: Food web in Waste Pond Habitat 
METEOROLOGY

Any evaluation of the impact of heat sink management alternatives on the environment must consider the $\mathrm{climate}$ of the region under consideration. Thus it is appropriate to describe the climate of the Hanford area in some detail.

General Climate

The basic reference on Hanford climate is the Climatography of the Hanford Area (Stone, Jenne, and Thorp, 1972). Temperature and precipitation data in this work indicate that the Hanford area borders between a steppe (BS) and desert (BW) climate using the Koppen classification scheme (Petterssen, 1958). This classification is confirmed by the vegetation types which occupy most of the Hanford Reservation.

Meteorological observations have been made at numerous locations in the Hanford vicinity, but the only extensive records for a single location are those for the Hanford Meterological Station (HMS). The HMS is located on a plateau at about $750 \mathrm{ft}$ above mean sea level and $300 \mathrm{ft}$ above the Columbia River, which flows through the Reservation from the northwest to the southeast. There are several significant topographic features within 20 miles of the HMS which affect aspects of the Hanford climatology.

Prior to the establishment of the HMS in December 1944, meteorological measurements were made by U.S. Weather Bureau cooperative observers between 1912 and 1943, and by the U.S. weather Bureau in Richland for a short period at the end of 1943 and beginning of 1944 .

The climatological data from these sources are summarized in Table 3. This summary gives both monthly and annual statistics for a large number of climatological variables and includes extreme values as well as mean values. 

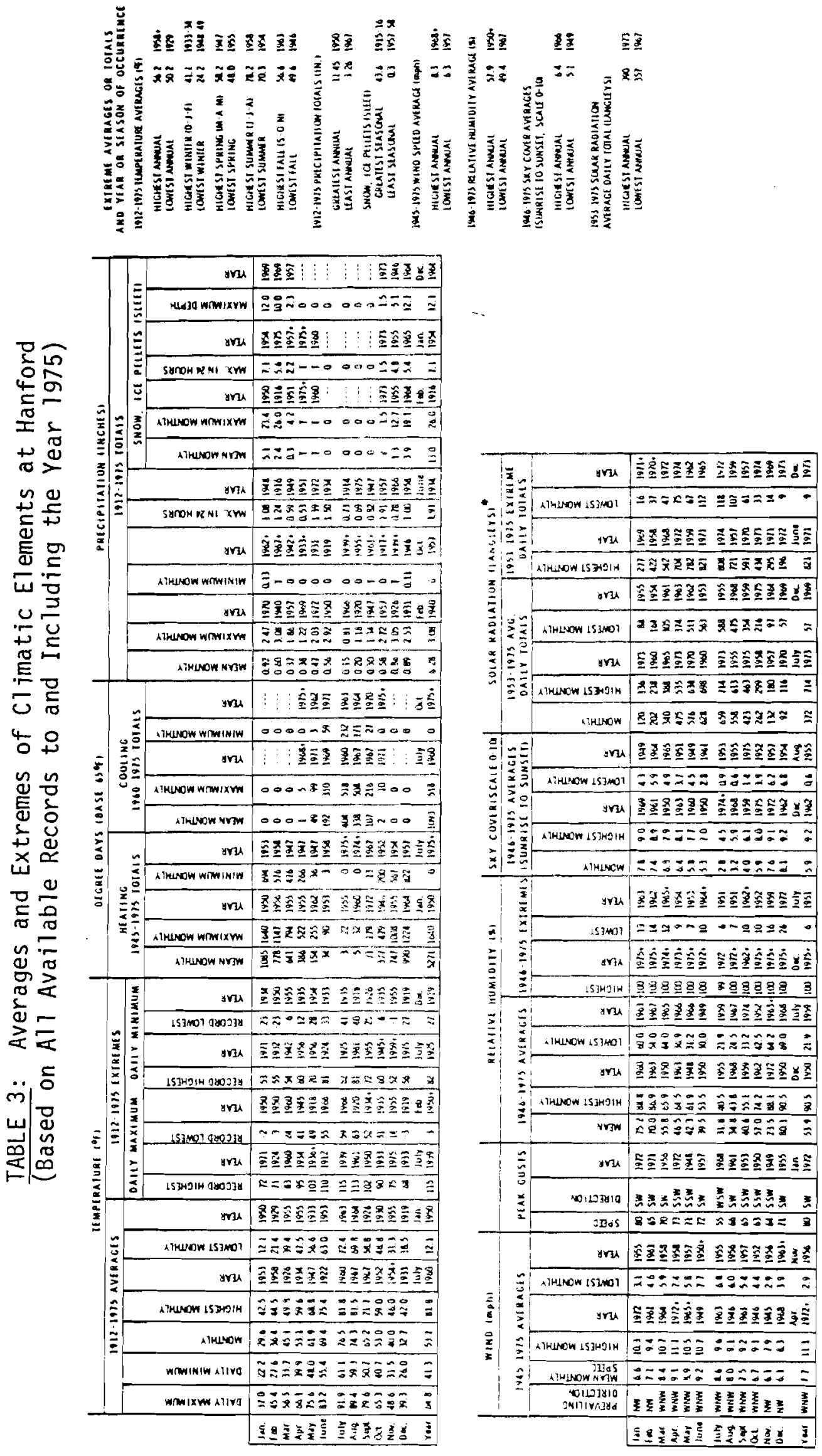

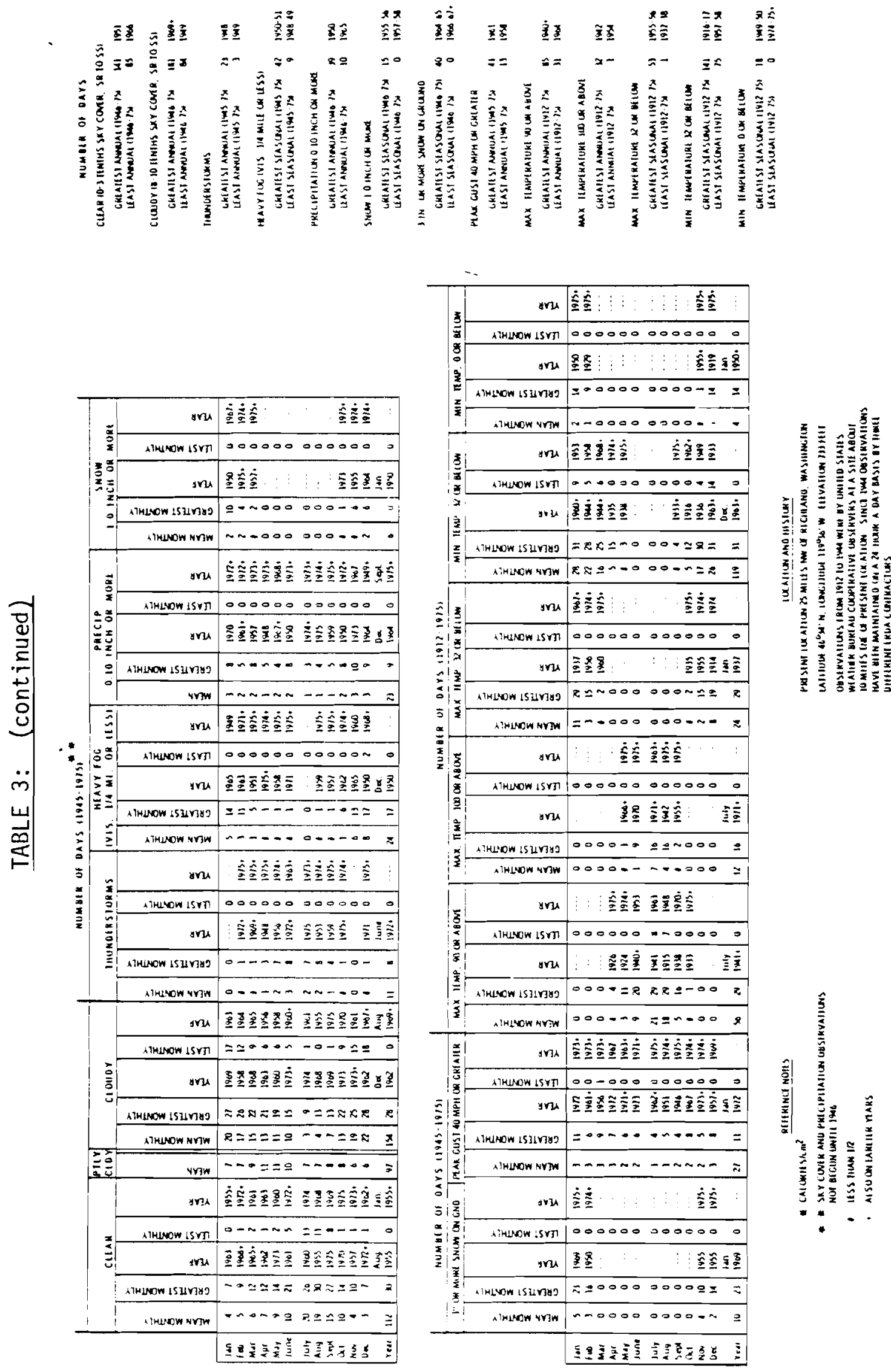
In addition to the month-to-month variation in the climatological statistics presented in Table 3 , there are distinct daily cycles which are superimposed on the seasonal variation. These daily cycles are most evident in temperature, humidity, and wind speed. The daily temperature cycle at Hanford ranges from about $13^{\circ} \mathrm{F}$ in December to $30^{\circ} \mathrm{F}$ in July and August.

The daily cycle of relative humidity is inversely related to the temperature cycle; that is, when the temperature decreases, the humidity increases. Conversely, when the temperature increases, the relative humidity decreases. The daily relative humidity variation at Hanford is about $25 \%$ throughout most of the year. However, it decreases to about $15 \%$ in December and January.

The daily wind speed cycle has a minimum during the morning hours and a maximum near sunset. It is most pronounced during the summer and aimost imperceptible during the months of December and January. Figures 7 and 8 show these daily cycles for the months of January and July respectively.

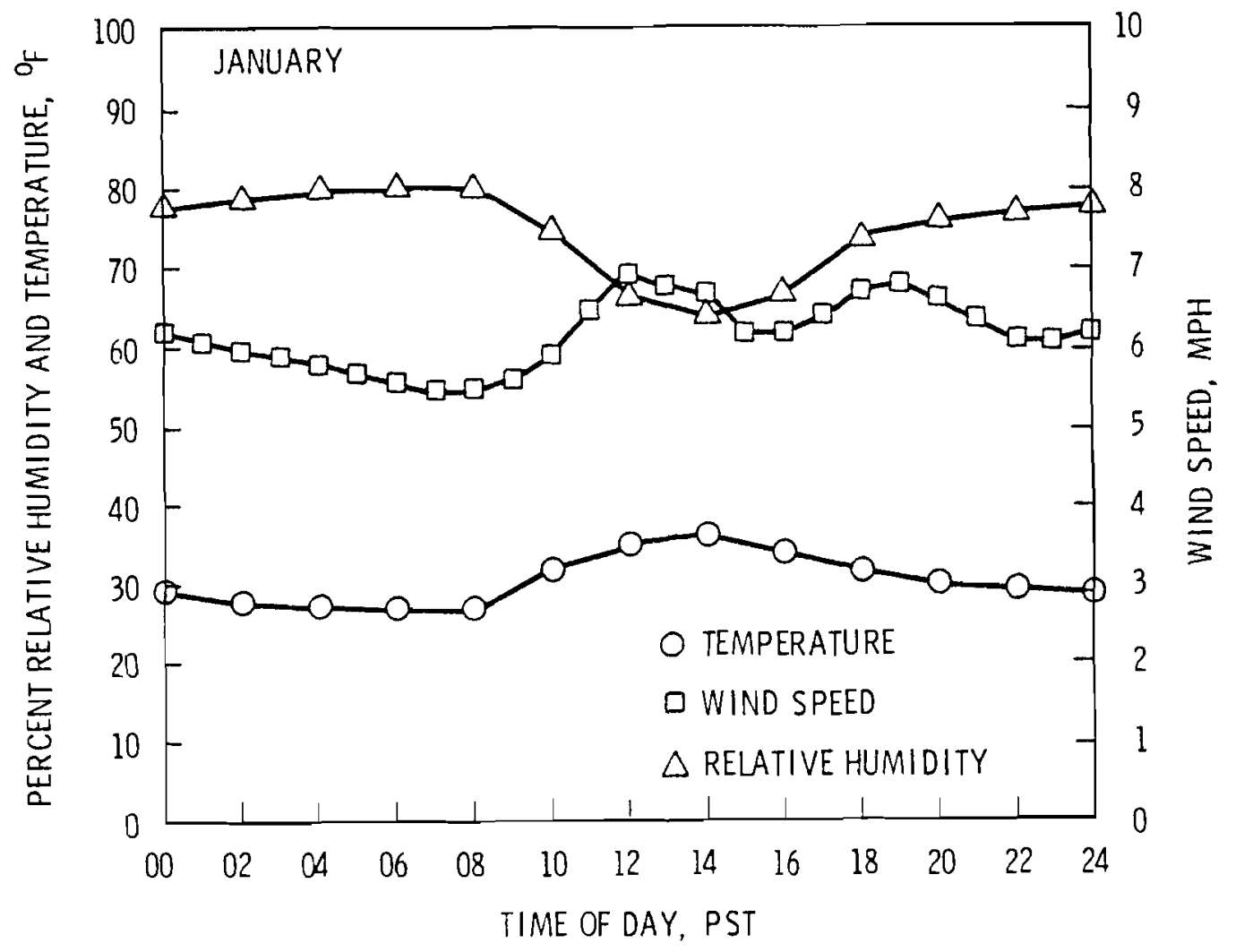

FIGURE 7: Daily Climatological Cycles - January 


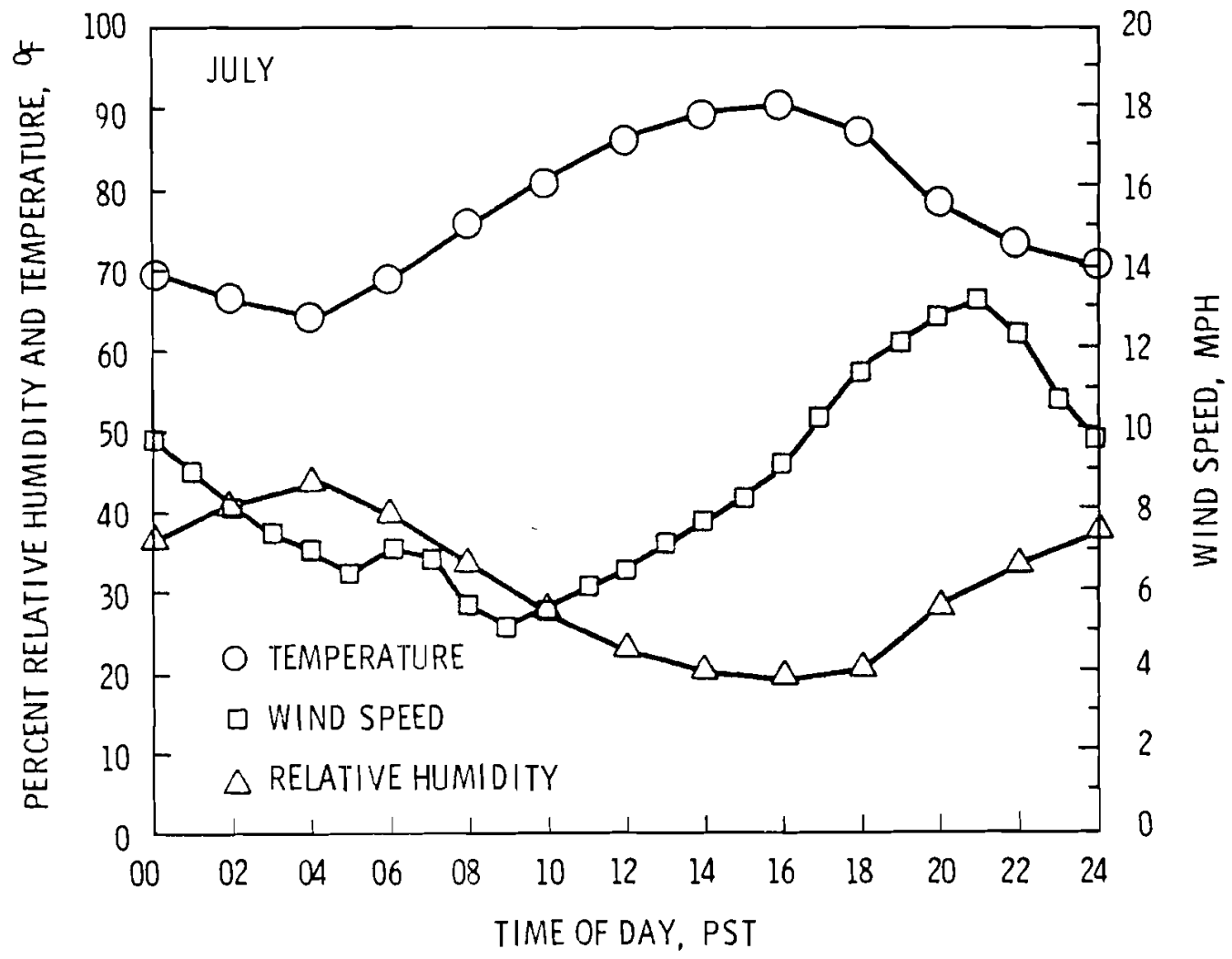

FIGURE 8: Daily Climatological. Cycles - July

The most frequent restriction to visibility in the Hanford area is fog which occurs on an average of 38 days per year. On 24 of these days the visibility is restricted to less than $1 / 2$ mile. Fog is highly seasonal, a) though it has occurred in every month. More than 95\% of the occurrences are from November through February. If the months of October and March are included this percentage increases to more than $99.5 \%$.

Hanford fogs are generally associated with low wind speed conditions. More than $70 \%$ of the hours of fog occur when the wind speed is less than $3.5 \mathrm{mph}$, and the average wind speed during fog is $2.5 \mathrm{mph}$. Table 4 gives detailed statistics on the hours and duration of both total and dense fog by months. It should be noted that January 1976 set a record for most hours of fog in a single month, 257. During that month fog was observed on a tota 1 of 20 days, including the last 16 days of the month. 
TABLE 4: Total Duration* and Maximum Persistence of Fog Tabulated in Hours for the Period 1945-1970

\begin{tabular}{|c|c|c|c|c|c|c|c|c|}
\hline $\begin{array}{c}\text { AL FOG } \\
\text { NIZ 0-6 MILES) } \\
\end{array}$ & $\begin{array}{l}\text { AVG TOTAL } \\
\text { OURATION } \\
\end{array}$ & $\begin{array}{l}\text { MAX TOTAL } \\
\text { DURATIGAU }\end{array}$ & YEAR & $\begin{array}{l}\text { MIN TOTAL } \\
\text { DURATION } \\
\end{array}$ & YEAR & $\begin{array}{l}\text { AVG DURATION PER } \\
\text { DAY OF OCCURREMICE } \\
\end{array}$ & MAX. PERSISTENCE ${ }^{(1)}$ & YEAR \\
\hline JAN & 68.3 & 193.4 & 1965 & 0 & 1949 & 7.2 & 58.1 & 1955 \\
\hline$F E B$ & 36.4 & 206.2 & 1963 & 0 & 1967 & 6.2 & 580 & 1963 \\
\hline MAR & 4.4 & 20.6 & 1951 & 0 & $1968+$ & 3.1 & 122 & 1949 \\
\hline APR & 03 & 28 & 1950 & 0 & $1970+$ & 1.4 & 28 & 1950 \\
\hline PAAY & a3 & 27 & 1958 & 0 & $1970+$ & 12 & 27 & 1958 \\
\hline JU:!E & $i$ & 0.5 & 1948 & 0 & $1970+$ & 0.5 & 0.5 & 1948 \\
\hline JL'LY & 1 & 0.7 & 1966 & 0 & $1970+$ & 0.7 & 0.7 & 1966 \\
\hline AUG & $i$ & 1.0 & 1859 & 0 & $1970+$ & 20 & 0.7 & 1959 \\
\hline SEPT & 0.3 & 5.5 & 1957 & 0 & $1970+$ & 20 & 26 & 1957 \\
\hline$\propto \top$ & 7.6 & 63.6 & 1962 & 0 & $1970+$ & 3.9 & 39.0 & 1962 \\
\hline NOV & 55.4 & 148.0 & 1952 & 1.0 & 1960 & 6.8 & 65.4 & 1963 \\
\hline DEC & 105.4 & 193.8 & 194 & 65 & 1968 & 8.7 & 72.3 & 1947 \\
\hline Y & 278.4 & $4625(1)$ & $1964-65$ & $147.7^{(2)}$ & $1488-49$ & 7.0 & 72.3 & $1947-48$ \\
\hline
\end{tabular}

DENSE FOG

$N \mid Z$ I/4 \&:I OR LESSI

\begin{tabular}{|c|c|c|c|c|c|c|c|c|}
\hline IAN & 20.4 & 524 & 1955 & 0 & 1949 & 3.4 & 15.0 & 1953 \\
\hline FEB & 127 & 86.7 & 1963 & 0 & $1967+$ & 3.8 & 16.7 & 1963 \\
\hline MAR & 1.8 & 7.8 & 1949 & 0 & $1968+$ & 22 & 5.0 & 1961 \\
\hline APR & 0.1 & 18 & 1855 & 0 & $1970+$ & 1.8 & 0 & $\cdots$ \\
\hline RAY & 0.1 & 1.6 & 1958 & 0 & $1970+$ & 1.6 & 26 & 1958 \\
\hline J:NE & 0 & 0 & --. & 0 & .... & 0 & 0 & --- \\
\hline$J L L Y$ & 0 & 0 & $\cdots$ & 0 & ---. & 0 & 0 & --- \\
\hline$A \cup G$ & 1 & 1.0 & 1959 & 0 & $1970+$ & 1.0 & 0.7 & 1959 \\
\hline SEPT & Q.1 & 3.2 & 1957 & 0 & $1970+$ & 3.2 & 1.4 & 1857 \\
\hline$C C T$ & 3.1 & 35.2 & 1962 & 0 & $1970+$ & 3.1 & 15.8 & 10,2 \\
\hline NOV & 21.1 & 71.4 & 1952 & 0 & 1960 & 41 & 22.6 & 1963 \\
\hline $0=C$ & 420 & 119.8 & 1947 & 1.3 & 1968 & 5.4 & 47.0 & 1957 \\
\hline$Y$ & 101.4 & $201.5(1)$ & $1.962-63$ & $47.3^{121}$ & $1948-49$ & 4.2 & 47.0 & $1 \$ 57-58$ \\
\hline
\end{tabular}

* TOTAL DURATION DENOTES TOTAL NUMBER OF HOURS AND TENTHS OF HOURS IN WHICH FOC IS OBSERVED.

I DENOTES LESS THAN QOS HOUR

(1) DENOTES THE GREATEST NUMHER OF HOURS IN A SEASON

(2) DENOTES THE LEAST NUNBBER OF HCURS IN A SEASON

(3) MAXIMUIT PERSISTENCE CF DENSE FOG IS BASED CN THE PERIOD 1953-70

The climatological data for the HMS are generally assumed to be representative of the entire region although local variations in the climate are known to exist. Important variations are those associated with the Columbia River and the major topographic features which form the sides of the basin. Differences between the northern and southern portions of the Hanford reservation are primarily small differences in temperature, humidity and wind. 
Diffusion Climatology

The major impact of an HNEC on the atmosphere wi11 come as a result of the release of waste heat. The extent of the impact will be further related to the ability of the atmosphere to disperse the heat. The primary factors which govern the dispersion or diffusion of the waste heat are atmospheric stability and the wind. The stronger the wind or less stable the atmosphere the more rapid the dispersion of the heat.

Results of numerous atmospheric diffusion experiments at Hanford indicate that four categories adequately describe atmospheric stability variations for the purpose of the diffusion modeling. Figure 9 shows wind roses for Hanford for each of these stability categories and for all categories combined. These wind roses clearly show that the prevailing wind direction at Hanford is from the west-northwest and northwest.

If the Hanford area were the Great Plains with no significant topographic features, the major impact of an HNEC would be expected to occur to the east-southeast and southeast. However, the influence of the topographic features in the Hanford area make this a very tenuous assumption. Air flow measurements made over the Reservation in the past few years indicate there are frequent local circulation patterns which are not adequately described by the wind direction at the HMS. Evidence of these local circulations is seen in Figure 10 which shows wind roses at several locations on and surrounding the Hanford Reservation. In some cases these circulations would act to increase the rate at which the waste heat is dispersed, and in other cases they would have the opposite effect. Figures 11 and 12 further demonstrate the differences in wind which can be observed at two places in relatively close promimity. The physical separation between the FFTF and the WNP-2 sites is about 2 miles, with the FFTF to the west of WNP-2. The large frequency of winds from south-southwest through west at the FFTF can be attributed to local circulations related to Rattlesnake Mountain or the west edge of the Hanford Reservation which do not affect WNP-2. 


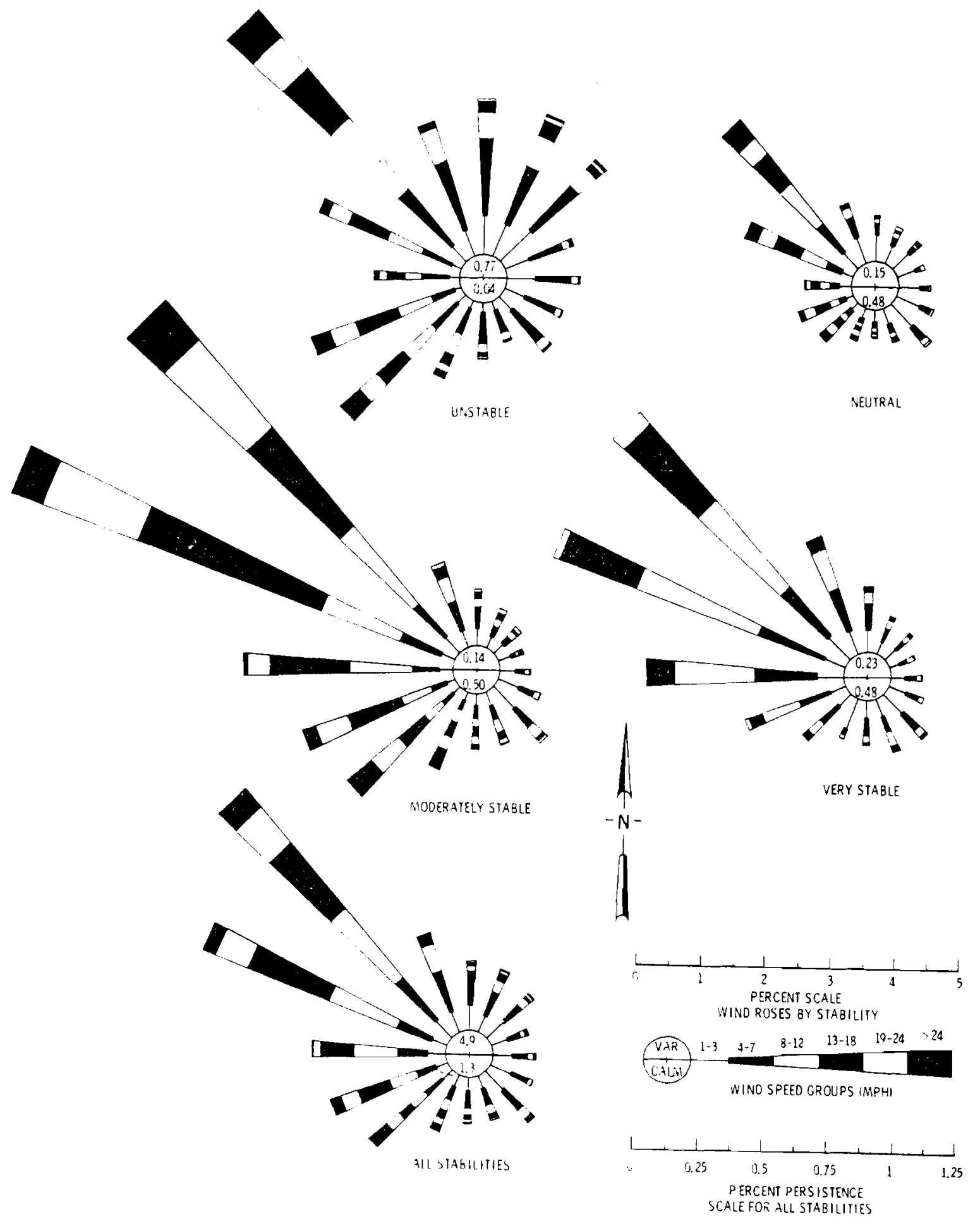

FIGURE 9: Wind Roses as a Function of Stability and Wind Speed at HMS Based on Winds at $200 \mathrm{Ft}$ and Air Temperature Stability Defined Between $3 \mathrm{Ft}$ and $200 \mathrm{Ft}$ for 1955 through 1970 (The points of the rose represent the directions from which the winds come.) 


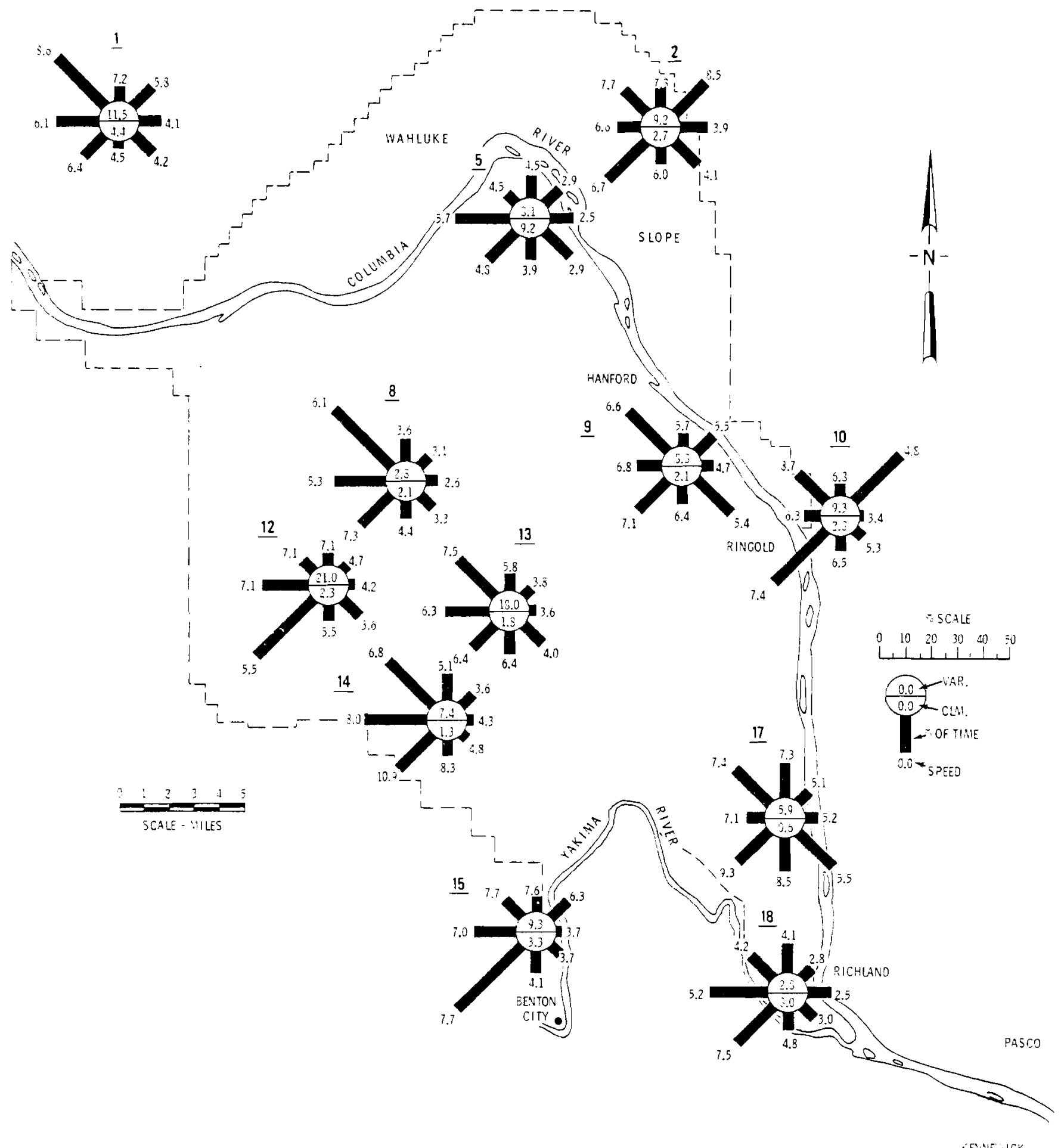

FIGURE 10: Surface Wind Roses for Various Locations on and Surrounding the Hanford Site (The points of the rose represent the direction from which the winds come.) 


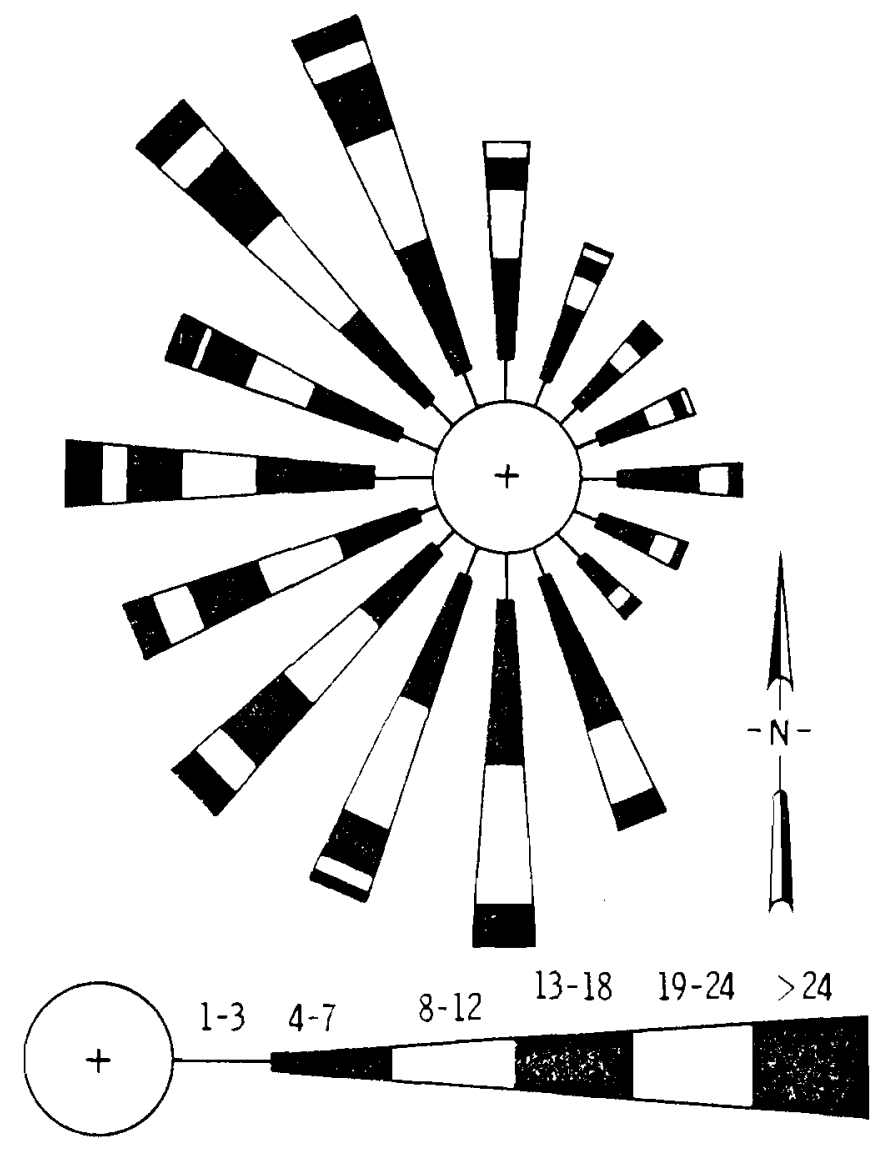

WIND SPEED GROUPS (MPH)
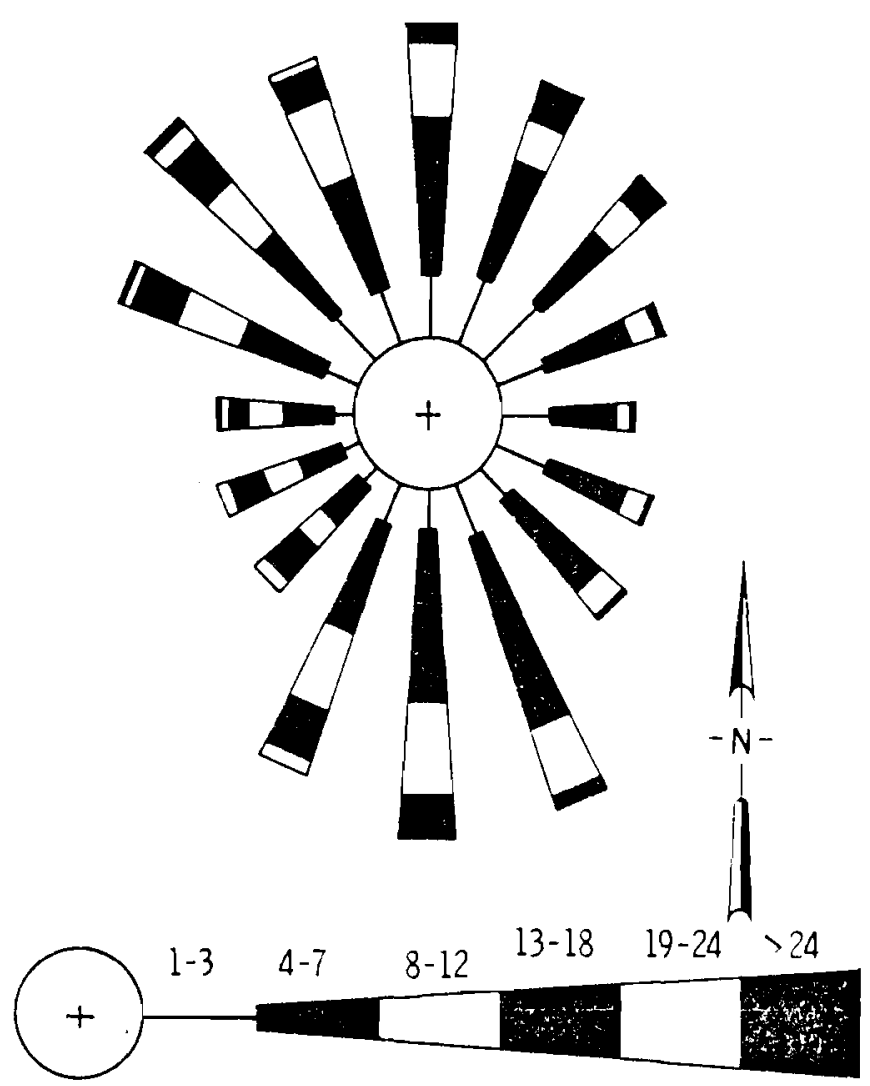

WIND SPEED GROUPS (MPH)

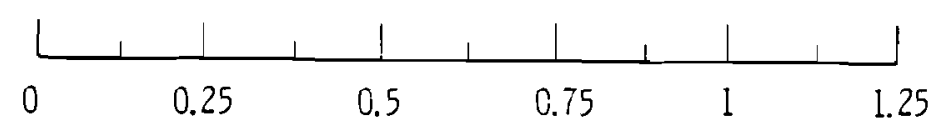

PERCENT PERSISTENCE

FIGURE 11: Wind Rose for the FFTF Site (At $13 \mathrm{ft}$, January 1, 1971 - July 1, 1973)

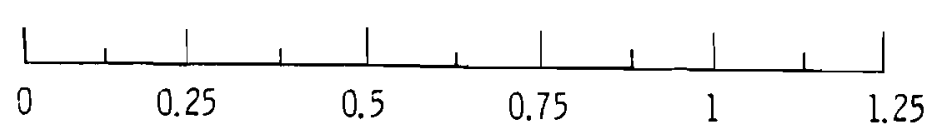

PERCENT PERSISTENCE

FIGURE 12: Wind Rose for the WNP-2 Site (At $23 \mathrm{ft}$, April 1972 - March 1973)

A detailed evaluation of the transport and diffusion of thermal effluents from a HNEC would be a complex and relatively expensive process as a result of the local circulations referred to above. Therefore a relatively simple dispersion model which uses HMS wind and stability data and assumes straight line transport has been used to examine the impact of various HNEC heat sink management alternatives on fog and humidity. The results of this evaluation are discussed later. 
THE HEAT SINK ALTERNATIVES

Study of the physical characteristics of the Hanford Project reveals that there are five possible methods for releasing large quantities of waste heat to the environment:

1. Once-through cooling using Columbia River water,

2. Cooling ponds,

3. Wet cooling towers,

4. Dry cooling towers, and

5. Wet-dry cooling towers.

Definite physical and administrative limits exist for some of these cooling methods (e.g., maximum permissible heat releases to the Columbia River) and may exist for a 11 methods if there are stringent atmospheric 1 imitations. Consequently, the first step in analyzing these alternatives is to determine the limitations on each cooling method. The second step then is to select and describe the several alternative cases for the HNEC cooling systems. These case descriptions then become the bases for the final comparison of the alternatives to determine the best cooling methods.

PHYSICAL LIMITATIONS ON COOLING METHODS

Operation of twenty power reactors would require release of about 50,000 MWt to the environment. The three general choices for release of that heat are: to the Columbia River, to the atmosphere by use of cooling ponds, or to the atmosphere by use of cooling towers.

The amount of heat that can be released for each of these methods is limited by administrative restrictions on the heat releases to the Columbia River, the availability of cooling pond land, or by the effects on the atmosphere. This section examines each of these modes to determine the obvious limitations on the amount of heat that can be disposed of by use of these methods. 
Heat Releases to the Columbia River

The maximum permissible heat release to the Columbia River near Hanford as established by the Washington State Water Quality Standards is defined by the formula:

$$
\Delta t=\frac{110}{T-15}
$$

where $\Delta t$ is the permissible average daily temperature rise and $T$ is the river temperature after all heat additions. No heat releases are permitted that would increase the river temperature above $68^{\circ} \mathrm{F}\left(20^{\circ} \mathrm{C}\right)$. In addition, heat releases must comply with the provisions of Public Law 92-500 which require that no releases be made after 1983 or releases be made such that they assure a balanced, indigenous population of shellfish, fish, and wildlife.

During the winter months. When maximum generation is desirable, the average daily river flow at Hanford varies from 36,000 to over 100,000 cfs. From 1960 to 1974, the minimum seven-day running mean flow rate varied from 54,000 to $103,000 \mathrm{cfs}$ and averaged $70,000 \mathrm{cfs}$. The minimum flow occurred only in August or September. At minimum river temperature when about a $5^{\circ} \mathrm{F}$ $\Delta t$ is permissible and the river flow often is close to the minimum, the maximum permissible heat release would be about 24,000 MWt at 70,000 cfs. This corresponds to 12,000 MWe (10 reactors). At 54,000 cfs flow, the permissible heat release is about 19,000 MWe, corresponding to eight reactors.

The minimum required flow at 36,000 cfs in the Hanford reach was estab1 ished when nine production reactors were operating at Hanford with oncethrough cooling. Since only one production reactor now is operating, this minimum required flow should be reevaluated with consideration of the future construction of an HNEC, current knowledge of effects of heat releases on the Columbia River aquatic ecology, and the effects of the additional storage reservoirs and hydroelectric capability in comparison to the time when the minimum flow requirement was established. Establishment of different minimum and average flows would affect the number of power plants that could have once-through cooling. 
During August and September, the river temperatures are higher $\left(>50^{\circ} \mathrm{F}\right)$ so that the maximum permissible heat release generally is less. As an example, in August, when the minimum flow rate is expected to be about 70,000 cfs and the river temperature is at $65^{\circ} \mathrm{F}$, the permissible $\Delta t$ is about $2.2^{\circ} \mathrm{F}$, corresponding to a maximum permissible heat release of 10,000 MWt or a generation of 5,000 MWe (4 reactors). In actuality, the number of reactors that could be operated in the summer in compliance with these standards probably would be lower than shown here because of river heating by other industries and by nature.

The amount of heat that can be released to the Columbia River without a significant effect on the aquatic life is not known. Historical data indicate that as much as an annual average of 23,000 MWt has entered the river from all causes between Priest Rapids and the City of Richland without evidence of a significant effect on the aquatic life (Jaske and Synoground, 1970). This occurred in 1965 when most of the Hanford production reactors were operating.

Therefore, it appears that up to ten reactors could operate with oncethrough cooling during the winter months, but many of these reactors would have to be shut down during the August to October period when the river temperatures are high. During some years when the river temperatures reach $68^{\circ} \mathrm{F}\left(20^{\circ} \mathrm{C}\right)$, a 11 reactors would have to be shut down during the high temperature period.

\section{Heat Releases to Cooling Ponds}

The possible heat releases from cooling ponds is determined primarily by the land area available for ponds. At Hanford about 2.5 acres of pond are needed per MWe of generating capacity in order to have condenser inlet temperatures near the temperatures of the Columbia River during the period from August to February (Jaske, 1971). A smaller pond area per MWe would result in higher condenser inlet temperatures, a lower power plant thermal efficiency, a higher power plant capital cost, and a higher annual fuel cost. 
A survey of available cooling pond sites identified the ponds that probably could be built without major effects on the Hanford Reservation water table or major expenditures such as pond lining (Table 5). (Construction of slurry trenches or intercept ditches might be necessary in some cases to prevent detrimental water table effects.)

In addition, several ponds might be built with liners to prevent water table effects (Figure 13 and Table 6). Most of these lined ponds are south of the 200 Areas and are not close to the selected HNEC power plant sites, but they might be operated as a single system cornected by canals to provide a large circular flow of cooling water.

These data indicate that the maximum capacity for cooling ponds would be about 16,000 MWe ( 13 reactors, maximum).

Heat Releases from Cooling Towers

Heat releases at cooling towers generally are limited by the maximum permissible atmospheric effects due to heat and moisture releases. The norma 1 amount of water loss by evaporation is about $30 \mathrm{cfs}$ for a 1250 MWe power plant or about 1200 cfs for 40 Hanford reactors. Although this is a large amount of water, it represents only one percent of the annual average flow of the Columbia River. Removal of that amount from the river probably would have an insignificant impact on the river as long as it is removed by use of intake pump structures designed for minimum impact.

Analysis of fog and humidity effects indicates that the atmospheric effects for cooling towers at Hanford will not limit the total heat releases from over 20 reactor $p l a n t s$ if the types for the towers are correctly selected. However, there may be a noticeable increase in fog on the Hanford Reservation. This is discussed in greater detail later in the atmospheric analys is for the several alternatives.

At Hanford, cooling towers must have mechanical draft. During high temperature, low humidity, summer conditions, natural draft towers do not 
TABLE 5: Unlined HNEC Cooling Ponds

\begin{tabular}{|c|c|c|c|}
\hline $\begin{array}{l}\text { Pond } \\
\text { Site }\end{array}$ & $\begin{array}{c}\text { Pond } \\
\text { Elevation } \\
(\mathrm{ft}) \\
\end{array}$ & $\begin{array}{l}\text { Pond Area } \\
\text { (acres) }\end{array}$ & $\begin{array}{l}\text { Capacity } \\
\text { (MWe) }\end{array}$ \\
\hline Wahluke West & 540 & 5,000 & 2,000 \\
\hline Wahluke East & 440 & 2,800 & 1,100 \\
\hline White Bluffs & 420 & 4,800 & 2,000 \\
\hline $100 \mathrm{~F}$ & 420 & 5,900 & 2,400 \\
\hline Riverland & 460 & 2,500 & 1,000 \\
\hline TOTAL & & 21,000 & 8,500 \\
\hline
\end{tabular}

TABLE 6: Lined HNEC Cooling Ponds

\begin{tabular}{lcccc}
$\begin{array}{c}\text { Pond } \\
\text { Site }\end{array}$ & $\begin{array}{c}\text { Pond } \\
\text { Elevation }\end{array}$ & & $\begin{array}{c}\text { Pond Area } \\
\text { (acres) }\end{array}$ & $\begin{array}{c}\text { Capacity } \\
\text { (MWe) }\end{array}$ \\
\cline { 1 - 1 } Gable Mountain & 480 & & 6,500 & 2,600 \\
NP & 440 & 3,000 & 1,200 \\
300 Area & 440 & 1,800 & 700 \\
300 Area Northwest & 440 & 2,000 & 800 \\
Horn Rapids & 500 & 2,300 & 900 \\
Cold Creek & 520 & 2,200 & 900 \\
Wye-West & 540 & 2,200 & 900 \\
\multicolumn{1}{c}{ TOTAL } & & $\underline{20,000}$ & 8,000
\end{tabular}




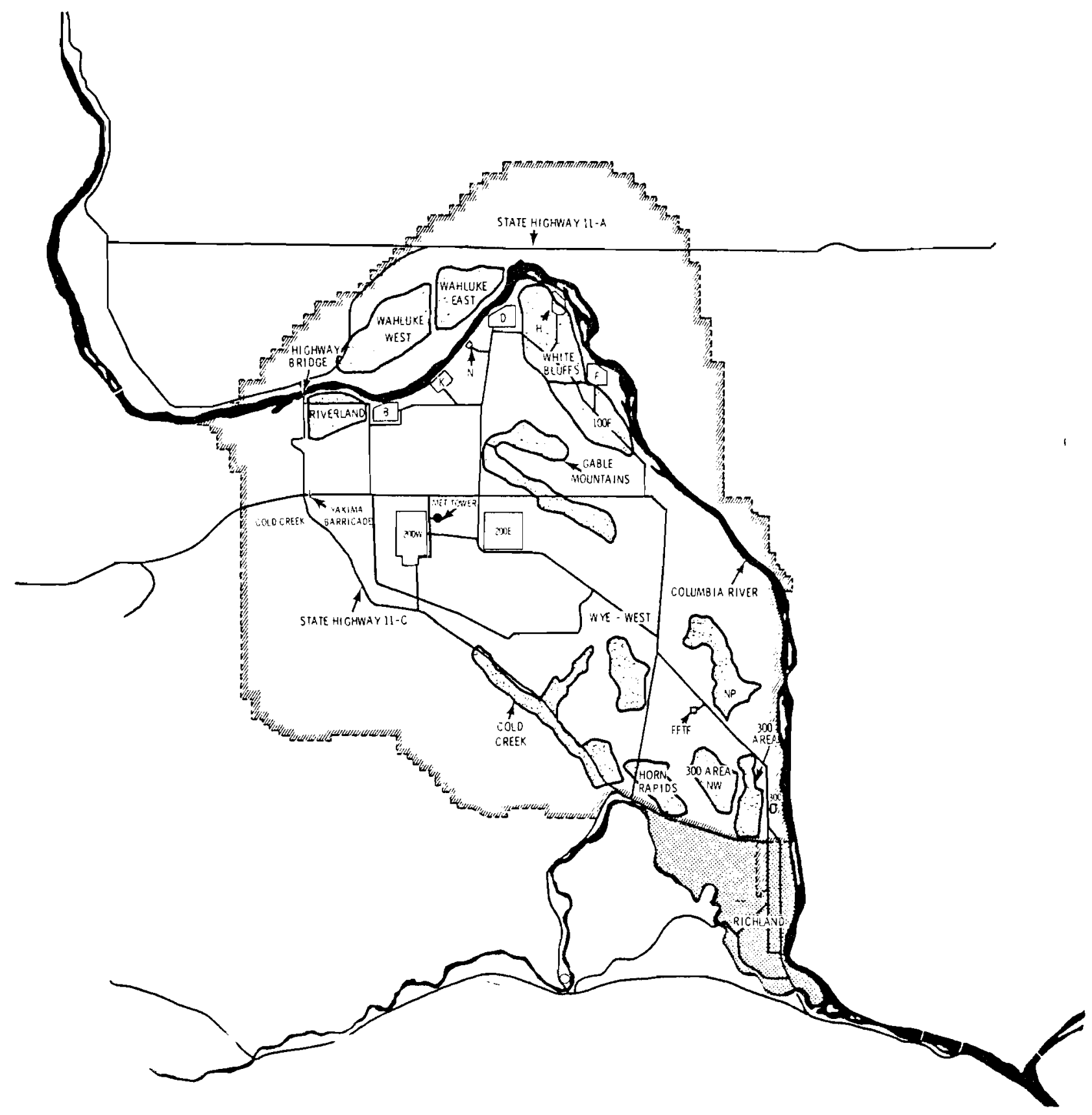

FIGURE 13: Potential Reactor Cooling Ponds 
generate sufficient air flow for satisfactory operation without a large increase in the condenser cooling water temperature.

\section{SELECTION OF THE COOLING METHOD CASES}

Twenty cases were compared to determine the best heat disposal methods for an HNEC. These cases covered various combinations of the available cooling methods and reactor sites, plus both 20 and 40 reactor HNECs. Selection of the cases for analysis was based on several general rules concerning the economic and environmental costs of cooling systems:

1. Once-through systems have the lowest economic costs.

2. Unlined cooling ponds and wet towers have intermediate economic costs.

3. Dry towers and lined cooling ponds have the highest economic costs.

4. Once-through cooling has the largest effects on aquatic ecology.

5. Pond cooling has the largest effects on terrestrial ecology.

6. Cooling pond operation results in maximum fog formation. .

7. Increasing the elevation of the moisture release reduces the occurrence of ground fog.

Eleven cases then were selected for the analysis of the 20 reactor HNEC (Table 7)* Figure 14 shows the HNEC plant sites. Eight of these cases were designed to describe extreme cases for specific environmental or economic effects as follows:

Cases I to IV Maximum moisture releases to the atmosphere

Case XI Highest construction and operating costs Maximum release of dry heat

Zero water use

Cases VI \& VII Maximum land use

\footnotetext{
*In al1 cases it was assumed that the three planned reactors at the WPPSS site will have short wet towers. A fourth reactor at that site would have either a short wet tower or a dry tower.
} 
TABLE 7: HNEC Heat Sink Alternatives Analysis Cases - 20 Reactors

\begin{tabular}{|c|c|c|c|c|c|c|c|c|}
\hline Case No. & $\begin{array}{c}\text { Case } \\
\text { Characteristics } \\
\end{array}$ & & lumber Reacto & at Specified & Sites & & & \\
\hline & & Wet Towers & Dry Towers & $\begin{array}{r}\text { Wet-Dry } \\
\text { Towers } \\
\end{array}$ & $\begin{array}{c}\text { Once-thru } \\
\text { Cooling } \\
\end{array}$ & $\begin{array}{l}\text { Closed } \\
\text { Cycle } \\
\text { Ponds } \\
\end{array}$ & $\begin{array}{l}\text { Helper } \\
\text { Towers } \\
\end{array}$ & $\begin{array}{l}\text { Cooling } \\
\text { Tower } \\
\text { Height } \\
\end{array}$ \\
\hline 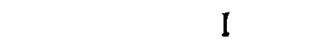 & Wet Tower & $401,2,3,4,85$ & & & & & & 75 \\
\hline 11 & Wet Tower & $4 @ 1,5,11,13 \& 14$ & & & & & & 75 \\
\hline II I & Wet Tower & 4 e $1,2,3,485$ & & & & & & $75^{\star}, 500$ \\
\hline IV & Wet Tower & 4 e $1,5,11,13 \& 14$ & & & & & & $75^{\star}, 500$ \\
\hline v & Wet-Dry Tower & 301 & 101 & 4 a $2,3,4,5$ & & & & 75 \\
\hline VI & Partial Once-thru & $401 ; 303$ & & & 103,$8 ; 405$ & $308 ; 404$ & & $75^{\star}, 500$ \\
\hline VII & Partial Once-thru & 401 & & & 104,$8 ; 405,10$ & 304,8 & & 75 \\
\hline VIII & Partial Unce-thru & $4 @ 1,3 ; 204$ & & & $204 ; 405,6$ & & & $75^{\star}, 500$ \\
\hline IX & Helper & 401 & . & & & & $404,5,6,8$ & $75^{\star}, 500$ \\
\hline$x$ & Full Once-thru & 4 อ 1 & & & $4 @ 4,5,8,10$ & & & 75 \\
\hline$x I$ & Dry Tower & 401 & $402,3,4,5$ & & & & & 75 \\
\hline
\end{tabular}

\footnotetext{
*Only wet towers at site 1 are $75 \mathrm{ft}$. in height.
} 


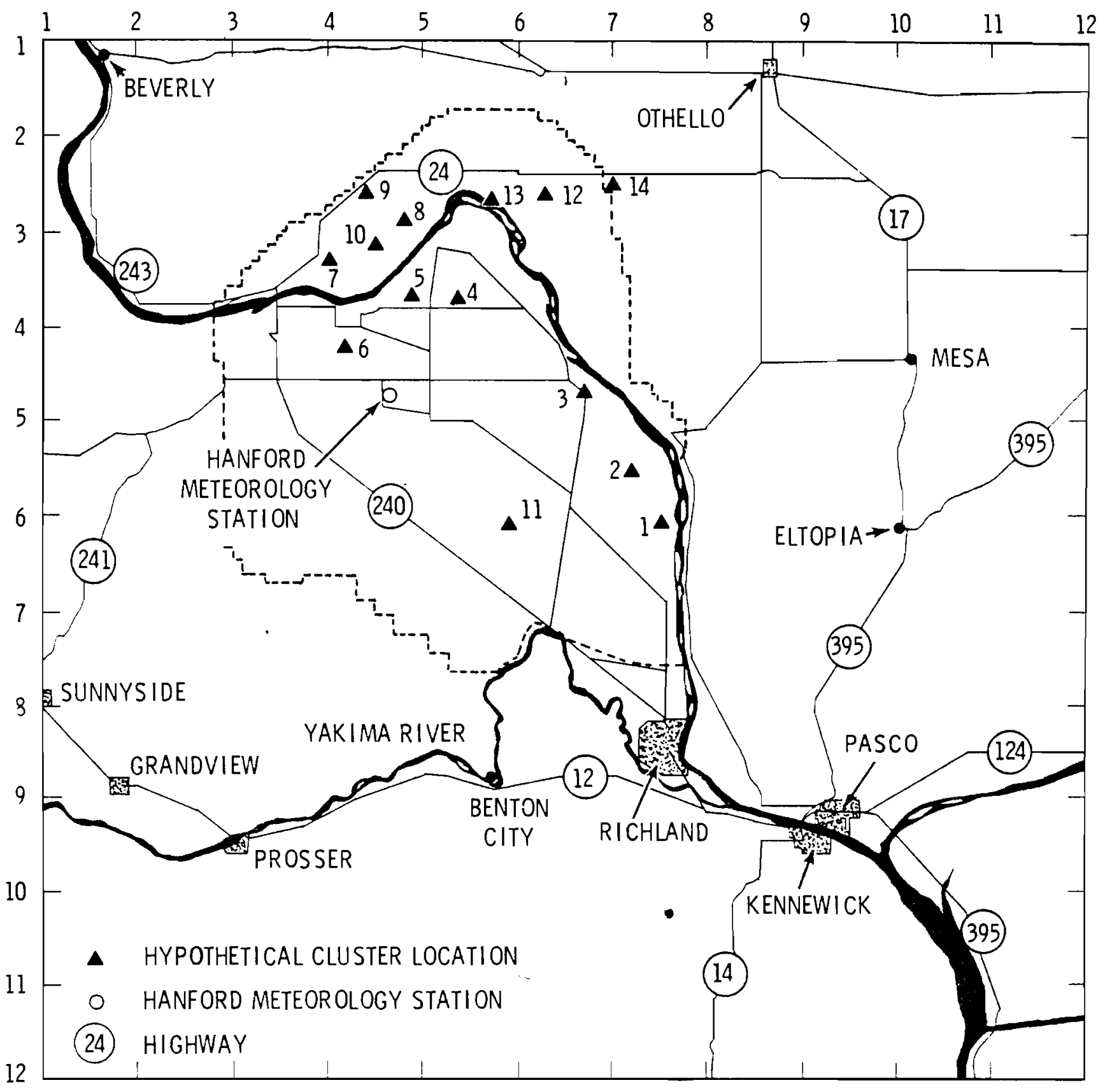

FIGURE 14: HNEC Plant Sites 
Case IX \& $X \quad$ Maximum water use

Cases II \& IV High elevations for moisture releases

The helper case IX was defined as once-through cooling with a ta11 wet cooling tower of the same design as is used for closed cycle wet towers. These towers would transfer $72 \%$ of the waste heat to the atmosphere. They could be bypassed during winter conditions as necessary to obtain optimum river temperatures.

Case $V$ was added to cover the possibility that use of only wet cooling towers would cause an excessive fog formation. For that case, use of $50 \%$ dry cooling was assumed to illustrate the costs and effects of wet-dry towers. The other cases are typical combinations of cooling systems.

In addition to the 11 cases for the 20 reactor $H N E C$, nine were also developed for the 40 reactor HNEC (Table 8 ). These cases are essentially the same as the cases for the 20 reactor HNEC.

No cases were included for lined cooling ponds in the southern portion of the project because of excessive economic and environmental costs in comparison to wet cooling towers. The economic cost would be much higher than for the wet towers because of the requirement of essentially zero leakage to prevent detrimental effects on the water table. The environmental effects are also expected to be larger than for wet towers because of (1) more land use, (2) more water evaporation in the summer causing a larger increase in relative humidity in Richland, and (3) increases of ground fog in the winter in Richland because the source of moisture is at ground level.

DESCRIPTION OF HEAT SINK ALTERNATIVES

Selection of Cost and Environmental Interaction Parameters

There are 24 general cost and environmental interaction factors that should be considered in a cost-benefit comparison (Table 9). Each of these is studied to determine if a significant impact may result and if a 


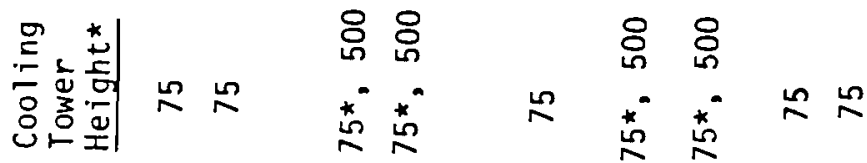

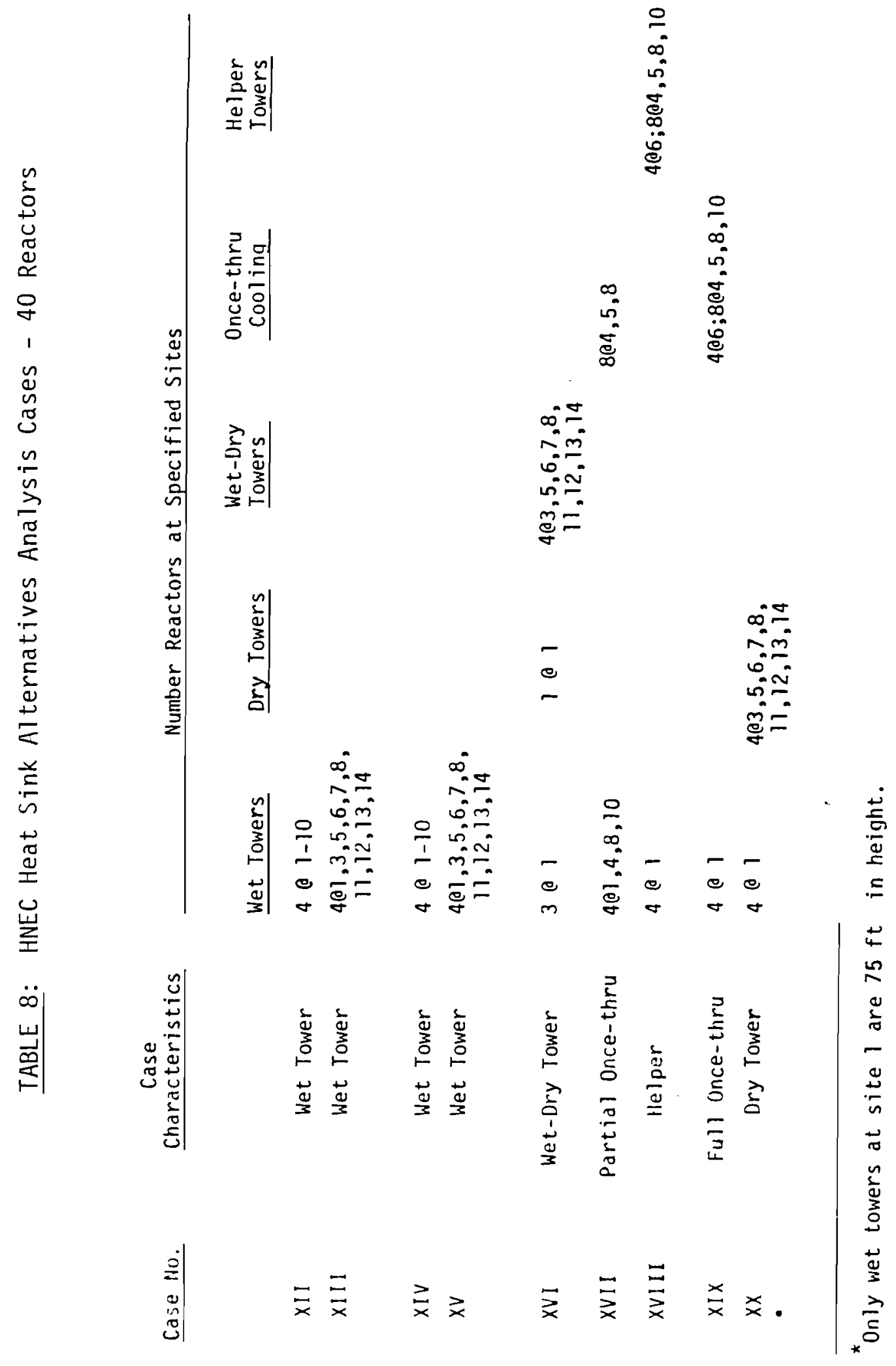


TABLE 9: General Evaluation

HNEC Cooling System Environmental Interaction Parameters

Parameter

Capital Costs

Operating Costs

Fue 1 Costs

Human Displacement

Land Use

Agricultural Effects

Water Use

Water Quality

Noise

Odors

Employment

Taxes

Social Attitudes

Navigation

Aquatic Biology

Terrestrial Biology

Meteorology

Radiation Doses

Fuel Shipments

Waste Disposal

Esthetics

Recreation

Historical

Archaeological
Significant?

Yes

Yes

Yes

No

Yes

Yes

Yes

Yes

No

No

No

No

Yes

No

Yes

Yes

Yes

No

No

Yes

Yes

Yes

No

Possibly
Reason

Large cost differences between al ternatives

Large cost differences between al ternatives

Large cost differences between alternatives

No permanent residents at sites

Reduction of recreational and wildlife use

Potential changes in meteorology

Large water uses necessary

Releases of chemicals in blowdown streams

No noise effects expected off project

No generation of odors expected

Probably trivial difference in operating and construction employment in comparison to total labor force

Secondary effect. Differences in taxes expected to be small

Societal reaction to changes in meteorolocy

No effect on navigation expected

Effects of river water use

Effects of land use

Effects of heat and water releases

No difference between alternatives

Insignificant difference between alternatives

Same as water quality

Cooling tower piumes

Loss of recreational lands

No important historical sites

Additional inforlation may be obtained from discovery or excavation of archaeological sites 
detailed evaluation should be made. If a detailed evaluation appears desirable, each factor is evaluated in depth for each of the alternatives for the system being considered.

A general evaluation of each of the 24 parameters is presented in Table 9. Included are the reasons why these parameters are considered significant or insignificant for a comparison of HNEC cooling system alternatives. This general evaluation showed that 15 of these parameters should be considered in greater detail during the evaluations. However, three of these are duplicates and one cannot be evaluated at this time, thereby reducing the total to 11 . The four that can be eliminated are as follows:

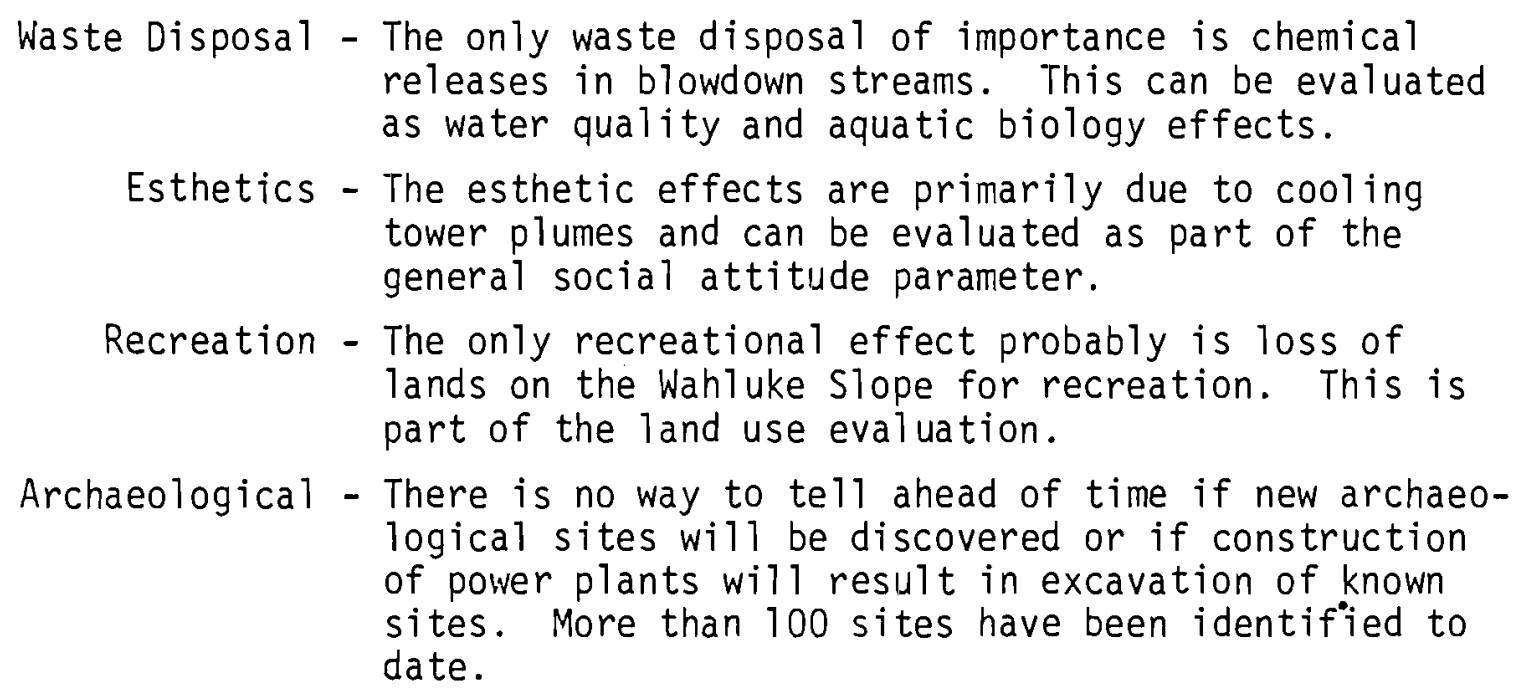
releases in blowdown streams. This can be evaluated as water quality and aquatic biology effects.

Esthetics - The esthetic effects are primarily due to cooling tower plumes and can be evaluated as part of the general social attitude parameter.

Recreation - The only recreational effect probably is loss of lands on the Wahluke Slope for recreation. This is part of the land use evaluation.

Archaeological - There is no way to tell ahead of time if new archaeological sites will be discovered or if construction of power plants will result in excavation of known sites. More than 100 sites have been identified to date.

The 11 environmental effect parameters that were evaluated in the cooling system comparison are:

$\begin{array}{ll}\text { Capital Costs } & \text { Aquatic Biology } \\ \text { Operating Costs } & \text { Terrestrial Biology } \\ \text { Fuel Costs } & \text { Meteorology } \\ \text { Land Use } & \text { Agricultural Effects } \\ \text { Water Use } & \text { Social Attitudes } \\ \text { Water Quality } & \end{array}$


Development of Specific Interaction Parameters

Capital Costs

The base reactor plant capital costs for this analysis were based on the estimated costs in the environmental statements for five four-unit nuclear power plants currently under construction or proposed by private utilities (Barton, Hartsville, North Anna, Shearon Harris, and Vogtle). The construction costs for the five example four-unit nuclear power plants are given in Table 10 .

TABLE 10: Typical Four-Unit Nuclear Power Plant Capital Costs

\begin{tabular}{|c|c|c|c|c|c|}
\hline & Barton & Hartsville & $\begin{array}{l}\text { North } \\
\text { Anna } \\
\end{array}$ & $\begin{array}{l}\text { Shearon } \\
\text { Harris }\end{array}$ & Vogtle \\
\hline Total Power (MWe) & 4836 & 4980 & 3854 & 3600 & 4636 \\
\hline \multicolumn{6}{|l|}{ Construction Cost } \\
\hline$\left(\$ \times 10^{5}\right)$ & 3059 & 2150 & 1033 & 1058 & 2196 \\
\hline$(\$ / k W)$ & 633 & 432 & 268 & 294 & 474 \\
\hline \multicolumn{6}{|l|}{ Startup Dates } \\
\hline Unit 1 & $9 / 83$ & $12 / 80$ & $12 / 74$ & $10 / 79$ & $4 / 80$ \\
\hline Unit 2 & $9 / 84$ & $6 / 81$ & $7 / 75$ & $10 / 80$ & $4 / 81$ \\
\hline Unit 3 & $9 / 85$ & $12 / 81$ & $3 / 77$ & $10 / 81$ & $4 / 82$ \\
\hline Unit 4 & $9 / 86$ & $6 / 82$ & $3 / 78$ & $3 / 82$ & $4 / 83$ \\
\hline Cooling System & $\begin{array}{l}\text { Natural } \\
\text { draft } \\
\text { towers }\end{array}$ & $\begin{array}{l}\text { Natural } \\
\text { draft } \\
\text { towers }\end{array}$ & $\begin{array}{l}13,000 \\
\text { acre } \\
\text { lake }\end{array}$ & $\begin{array}{l}\text { Natural draft } \\
\text { to'wers plus } \\
4000 \text { acre lake }\end{array}$ & $\begin{array}{c}\text { Natural } \\
\text { draft } \\
\text { towers }\end{array}$ \\
\hline
\end{tabular}

Correlation of the construction costs for these plants shows an average cost escalation of ten percent per year and a construction cost of about $\$ 290 / \mathrm{kW}$ for startup of the first unit late in 1975 . (The Shearon Harris costs were not included in the correlation because they appear to be anomalously low -- see Figure 15.) The resultant total capital cost for a 5,000 Mwe cluster starting operation of the first reactor on January 1, 1976, would be about $\$ 1.5$ billion.

Although construction costs for nuclear power plants have escalated rapidly since the original estimates, and future costs will probably escalate at a similar rate, use of these costs is not expected to affect the 


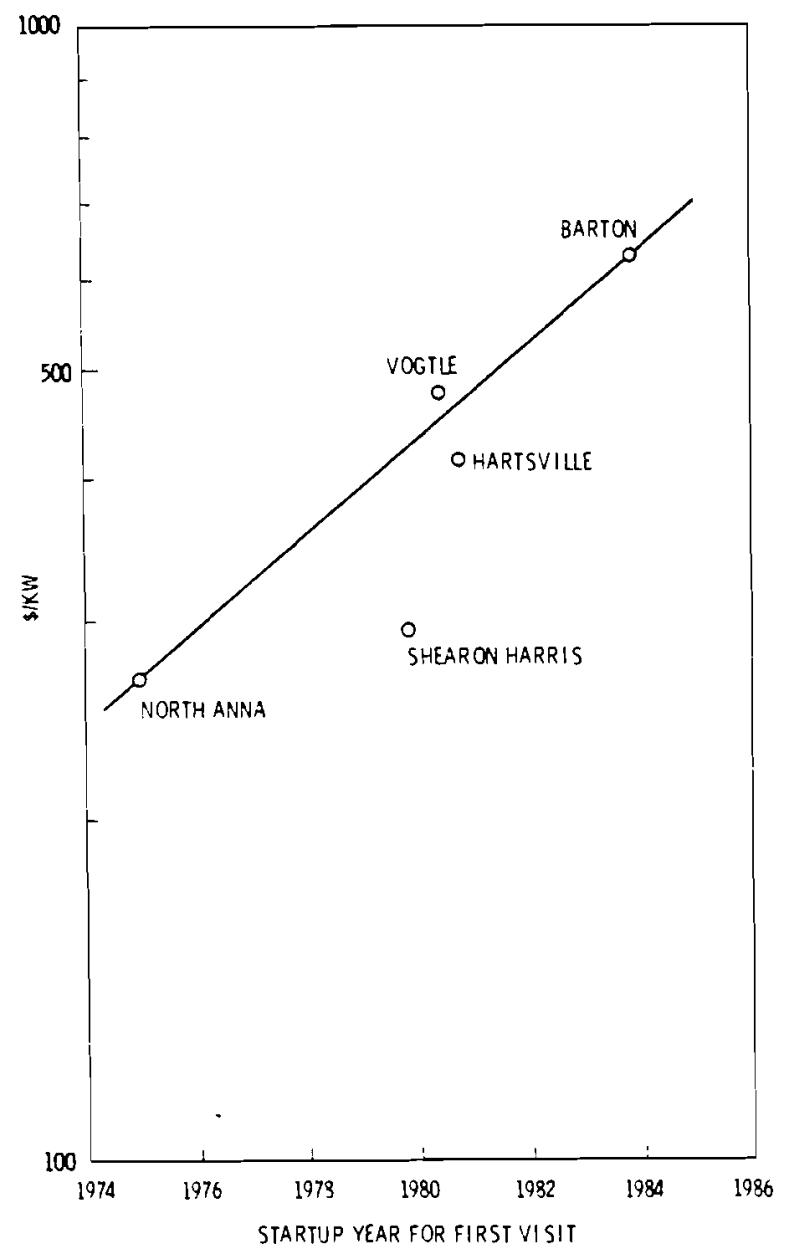

FIGURE 15: Cost Correlation for Four-Unit Nuclear Power Stations

conclusions of this document. The relationship between the economic and environmental costs should remain the same because the environmental values presumably will escalate at the same rate as for the economic costs.

Al though the power plants correlated on Figure 15 have somewhat different types of cooling systems, the general correlation of that figure still appears valid. Four of the five have natural draft towers and the cost of the North Anna lake is similar to the cost of cooling towers for that plant.

The capital cost data for the four-unit stations ( $\$ 290 / \mathrm{kWe})$ is for natural draft towers. Since a mechanical draft tower costs about $\$ 2 /$ kWe less than a natural draft tower, the capital cost for a HNEC reactor plant using short mechanical draft towers is estimated to be $\$ 288 / \mathrm{kWe}$. Similarly, based on 
information in the literature and the construction conditions at Hanford, the capital costs for other cooling modes were estimated to be:

$\begin{array}{lr}\text { Once-through } & \$ 275 / \mathrm{kWe} \\ \text { Unlined cooling ponds } & 285 / \mathrm{kWe} \\ \text { Helper cooling towers } & 300 / \mathrm{kWe} \\ \text { Lined cooling ponds } & 316 / \mathrm{kWe} \\ \text { Unlined helper cooling ponds } & 295 / \mathrm{kWe} \\ \text { Lined helper cooling ponds } & 326 / \mathrm{kWe} \\ \text { Dry cooling towers } & 330 / \mathrm{kWe}\end{array}$

These unit capital costs include the effects of differences in the thermal power level of the reactors because of differences in the condenser cooling water temperatures. The assumed thermal efficiencies and reactor thermal power levels are shown in Table 11.

TABLE 11: Power Plant Efficiencies

\begin{tabular}{|c|c|c|}
\hline Cooling Mode & $\begin{array}{l}\text { Net Thermal } \\
\text { Efficiency }(\%)\end{array}$ & $\begin{array}{c}1250 \text { MWe } \\
\text { Reactor Therma1 } \\
\text { Power Level (MWt) }\end{array}$ \\
\hline Once-through & 33 & 3,790 \\
\hline Ponds & 32.5 & 3,850 \\
\hline Wet Towers & 32 & 3,900 \\
\hline Dry Towers & 30 & 4,170 \\
\hline
\end{tabular}

In those cases where tall fan-assisted mechanical draft cooling towers are used, a separate tower system is assumed to be constructed for each reactor. The additional shell cost is expected to add about 20 percent to the tower construction cost, resulting in a total plant capital cost of $\$ 290 / k$ We.

Operations and Maintenance Costs

The operation and maintenance (0\&M) costs for a power plant can be considered to have two components: (1) the cooling system costs and (2) a11 other costs. All other costs can be treated as a constant when cooling system alternatives are compared. 
The cooling system 0\&M costs vary between alternatives primarily because of differences in equipment and maintenance costs. Typical power requirements and costs assumed for the various alternatives are given in Table 12.

\section{TABLE 12: Typical 0\&M Costs}

Cooling System

Once-through

Mechanical Draft Tower (wet)

Mechanical Draft Tower (dry)

Ponds

\section{Power Requirement (MW)}

5.0

15.1

27.8

6.8
$0 \& M$ Cost $(M i 11 \mathrm{~s} / \mathrm{kWh})$ 2.0 (Base)

2.1

2.3

2.1

The difference in power requirements for the various alternatives was considered during determination of the net thermal efficiencies, the power plant thermal power levels, and the gross electricity generations.

Fuel Costs and Plant Factors

The fuel cost was assumed to be $1.32 \mathrm{mills} / \mathrm{kWht}$ (i.e., typical $\mathrm{CY} 1976$ costs). The plant factor was assumed to be 70 percent of all alternatives.

\section{HNEC Land Areas}

A survey of five nuclear power plant clusters containing four reactors (Barton, Hartsville, North Anna, Shearon Harris, and Vogtle) revealed that the main plant systems, including cooling towers, occupy about 300 acres. The total site areas varied from 1,000 to 19,000 acres, most of which was unoccupied or occupied by cooling ponds. Use of once-through cooling (on lakes) appears to require about the same amount of land as use of cooling towers. However, this conclusion probably results more from the use of available land areas than from an attempt to use a minimum amount of land.

Because large low-cost land areas are available at Hanford, a11 fourreactor plant sites are assumed to occupy one square mile (except for cooling pond cases), regardless of the type of cooling system used. This allows 
ample room for all facilities (reactors, cooling towers, substations, etc.) at optimum locations for economic and operational reasons. Because of the low land costs at Hanford, attempts to define the exact land areas required for specific cooling systems would be futile because differences in construction costs as the land areas are minimized probably would be much larger than the change in land values.

\section{Material Use}

The primary materials used in cooling systems are concrete and steel. Much smaller quantities of other materials are generally used. A survey of the literature and discussions with utilities and cooling tower vendors indicates that typical quantities of materials for the various types of cooling systems are as shown in Table 13.

\section{TABLE 13: Cooling System Materials}

Cooling System

Cooling system

Once-through

Unlined cooling ponds

Short mechanical draft cooling towers

Tall mechanical draft cooling towers

Dry cooling towers
Material per 1,250 MWe Reactor

\begin{tabular}{cc}
$\begin{array}{c}\text { Concrete } \\
\text { (cubic yards) }\end{array}$ & $\begin{array}{r}\text { Stee }) \\
\text { (tons) }\end{array}$ \\
\hline 13,000 & 3,300 \\
14,500 & 3,700 \\
36,000 & 4,000 \\
40,000 & 4,000 \\
37,000 & 10,000
\end{tabular}

\section{Water Utilization}

A11 water used in the cooling systems is obtained from the Columbia River and then evaporated or returned to the river. The quantity depends on the time of year and the final optimization of the plant designs. Based on current industrial practices and Hanford meteorological conditions, the water utilization per reactor is as shown in Table 14 . 
TABLE 14: Water Use for Various Cooling Systems

\begin{tabular}{|c|c|c|c|}
\hline $\begin{array}{l}\text { Cooling } \\
\text { System }\end{array}$ & $\begin{array}{l}\text { Intake from } \\
\text { River (cfs) }\end{array}$ & $\begin{array}{c}\text { Evaporation } \\
\text { Rate }^{*} \\
\text { (cfs) } \\
\end{array}$ & $\begin{array}{l}\text { Discharge to } \\
\text { River (cfs) }\end{array}$ \\
\hline Once-through & 1,500 & ** & 1,500 \\
\hline Helper towers & 1,500 & 22 & 1.478 \\
\hline Cooling ponds & 60 & 45 & 15 \\
\hline Wet towers & 40 & 30 & 10 \\
\hline Dry towers & 0 & 0 & 0 \\
\hline
\end{tabular}

*Ful1 power operation.

**Not determined. Evaporation will occur downstream of the reactor plant. The amount will depend on the number of reactors with once-through c00ling and whether a surface or submerged discharge is used, but it is expected to be smaller than for closed cycle systems.

\section{Chemical Releases}

The two types of chemical releases from cooling systems are the drift from wet cooling towers and the biocides and corrosion inhibitors in the blowdown stream from closed cycle cooling systems. The amount of chemicals in the drift from the wet tower for one reactor is estimated to be about five tons per year or an average of up to $200 \mathrm{lb}$ per acre per year deposited on nearby lands. The chemicals in the blowdown streams for one reactor are estimated in Table 15.

TABLE 15: Chemical Releases from Wet Towers and Cooling Ponds

Chemical

$\frac{\text { Quantity (tons/year) }}{\text { Wet Towers }}$

Total dissolved solids*

700

6,300

Copper

7

10

Free available chlorine

3.5

5

Total phosphorus

\footnotetext{
*Primarily derived from dissolved solids in makeup water from the river.
} 


\section{Aquatic Ecological Effects}

The possible impacts of power stations on the economically important fish population, both resident and migratory, and their supporting food base obviously will be influenced by a number of design features, including the condenser cooling methods (once-through or closed cycle), location of the water intake and discharge structures, and the chemical characteristics of the liquid effluents discharged to the river. For these reasons the analysis of potential impacts on aquatic organisms will be based on assumed sets of power plant conditions and are subject to change or refinement with further plant development.

Once-through cooling. Because of the large volume of water withdrawn and discharged by once-through units and the increased temperatures of their effluents, they could have a significant impact on the river biota. These power stations probably will be upstream from some of the major salmon spawning areas and on the opposite side of the river (Figures 2 and 14). Careful design of the thermal discharge system will be required to (1) minimize the exposure of the salmon spawning areas to the plant effluents and (2) reduce the possibility of creating a thermal block to the upstream movement of anadromous fish. The movement of chinook salmon and steelhead trout and possibly other salmon is along the north shore in the Hanford reach of the river; and there is a clear avoidance response by these fish to heated effluent discharged along the shore, but not to the main centerchannel outfalls. Shoreline zones receiving heated water also produced mortalities to juvenile salmon drifted slowly through these areas (Becker and coutant, 1970). Passage of young salmon through the mid-channel thermal discharges produced no mortalities.

The most critical period for possible thermal effects on the local race of salmon is during the first three weeks in October at the start of spawning and continuing for about one month thereafter. River temperatures at this time average about $60^{\circ} \mathrm{F}$ (range 56 to $65^{\circ} \mathrm{F}$ ) (Watson, 1970). An increase above these temperatures may produce a delay in spawning and possible mortality in the adult population and reduce the survival of the 
spawn. The recommended optimum temperatures for certain stages of the salmon life cycle are as follows (EPA, et al., 1971):
Migration routes
$45-60^{\circ} \mathrm{F}\left(7.2\right.$ to $\left.15.6^{\circ} \mathrm{C}\right)$
Spawning route
$45-55^{\circ} \mathrm{F}\left(7.2\right.$ to $\left.12.8^{\circ} \mathrm{C}\right)$
Rearing areas
$50-60^{\circ} \mathrm{F}\left(10\right.$ to $\left.15.6^{\circ} \mathrm{C}\right)$

Temperatures of the Columbia historically have exceeded the desired temperature ranges, particularly for migration and spawning. In laboratory studies chinook salmon eggs were spawned in 0ctober at a base river temperature of $56^{\circ} \mathrm{F}$ and incubated at $2^{\circ} \mathrm{F}$ increments above the river ambient. These tests showed increased embryonic and larval mortalities at temperatures greater than $4^{\circ} \mathrm{F}$ above that of the river as shown in Table 16 and Figure 16 (Nakatani, 1969). Thermal additions to salmon eggs that started incubation in late November and December, when river temperatures were 54 to $48^{\circ} \mathrm{F}$, resulted in a much lower increase in mortality. The fish hatched from these spawns had a much better growth rate when maintained at up to $12^{\circ} \mathrm{F}$ above ambient river temperatures. Warming the river during the winter may be beneficial to embryonic and early larval development.

In the past, the salmon spawning areas downstream from the proposed once-through cooled power plants received the heated effluents from up to nine plutonium production reactors with no observed changes in the local salmon population or other river biota attributable to that discharge (Watson, 1970). The temperatures of these effluents were in "excess of $185^{\circ} \mathrm{F}^{\prime \prime}$ (Derouin, 1972). The volume of effluent discharge from these reactors is classified, but did include $1256 \mathrm{cfs}$ discharge at an average $\Delta t$ of about $34^{\circ} \mathrm{F}$ from the Washington Public Power Supply System (WPPSS) steam plant at 100- $\mathrm{N}$ Area. The fact that these past heated discharges have produced no measurable changes in the river ecosystem lends support to the feasibility of establishing a limited number of once-through cooled plants along the Columbia in the interest of a balanced environmental impact.

Recent research on the ecological effects of the WPPSS Hanford-N steam plant provides a basis for estimating possible changes that may be expected for once-through cooling. Some of the observed biological effects are: 
TABLE 16: Mortality and Growth of Young Chinook Salmon Reared Under Elevated River Temperatures

\begin{tabular}{|c|c|c|c|c|c|c|c|c|c|}
\hline \multirow{4}{*}{\multicolumn{2}{|c|}{$\begin{array}{l}\text { Date Spawned } \\
\text { Date Terminated } \\
\text { Initial Base Temp. } \\
\text { of }\end{array}$}} & \multirow{2}{*}{\multicolumn{2}{|c|}{$\begin{array}{r}10 / 30 / 66 \\
4 / 24 / 67\end{array}$}} & \multicolumn{2}{|c|}{$11 / 14 / 66$} & \multicolumn{2}{|c|}{$11 / 23 / 66$} & \multicolumn{2}{|c|}{$12 / 8 / 66$} \\
\hline & & & & \multirow{2}{*}{\multicolumn{2}{|c|}{$5 / 9 / 67$}} & \multirow{2}{*}{\multicolumn{2}{|c|}{$5 / 18 / 67$}} & \multicolumn{2}{|c|}{$6 / 2 / 67$} \\
\hline & & & & & & & & & \\
\hline & & & & & & 5 & & 4 & \\
\hline Lot & $\begin{array}{l}\text { Temperature } \\
\text { Condition }\end{array}$ & $\begin{array}{l}\text { \% Mor- } \\
\text { tality }\end{array}$ & $\begin{array}{l}\text { Mean } \\
w t, g\end{array}$ & $\begin{array}{l}\text { \% Mor- } \\
\text { tality }\end{array}$ & $\begin{array}{l}\text { Mean } \\
w t, g\end{array}$ & $\begin{array}{l}\text { \% Mor- } \\
\text { tality }\end{array}$ & $\begin{array}{l}\text { Mean } \\
w t, g\end{array}$ & $\begin{array}{l}\text { \% Mor- } \\
\text { tality }\end{array}$ & $\begin{array}{l}\text { Mean } \\
w t, g\end{array}$ \\
\hline 1 & Control (a) & 4.6 & 0.95 & 10 & 0.63 & 5.5 & 0.64 & 4.8 & 0.63 \\
\hline 2 & $+2^{\circ} \mathrm{F}$ & 3.6 & 1.40 & 11 & 0.96 & 9.3 & 0.97 & 5.5 & 0.97 \\
\hline 3 & $+4^{\circ} \mathrm{F}$ & 11 & 1.92 & 16 & 1.53 & 12 & 1.37 & 7.5 & 1.42 \\
\hline 4 & $+6^{\circ} \mathrm{F}$ & 28 & 2.72 & 19 & 2.55 & 9.4 & 1.96 & 7.3 & 1.79 \\
\hline 5 & $+8^{\circ} \mathrm{F}$ & 60 & 4.28 & 17 & 4.17 & 6.9 & 2.61 & 17 & 2.31 \\
\hline 6 & $+10^{\circ} \mathrm{F}$ & 97 & - & 43 & 5.52 & 10 & 3.82 & 14 & 3.18 \\
\hline 7 & $+12^{\circ} \mathrm{F}$ & 100 & - & 93 & 5.65 & 37 & 5.28 & 12 & 4.24 \\
\hline
\end{tabular}

(a) OSimilar to temperature at Priest Rapids Dam

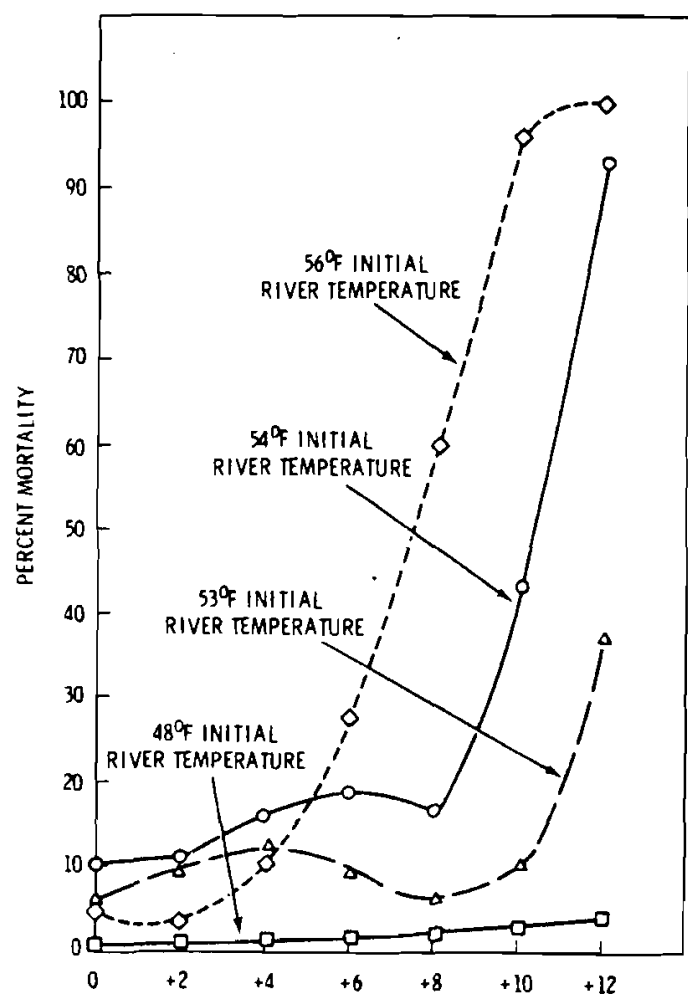

INCREASE IN REARING TEMPERATURE ABOVE RIVER TEMPERATURE

FIGURE 16: Salmon Embryonic and Larval Mortalities 
1. Passage of phytoplankson through the cooling system reduced primary productivity within the system. No decrease in primary productivity downstream of the plant discharge could be measured.

2. About half of the zooplankton were killed in passage through the cooling system.

3. Benthic organism production in areas receiving warm effluents was increased and remained active longer into the winter.

4. There was no fish survival after passage through the cooling system.

Particular care must be given to the design of the water intakes to reduce fish loss from impingement and entrainment. Studies of the shoreline water intake at the WPPSS steam plant (Page, et a1., 1975; Gray, et a1, 1975) show that up to 18 percent of the juvenile salmon produced between the intake and Priest Rapids Dam are lost through impingement; and up to 9 percent are killed by passage through the cooling system. If proportionally similar losses, based entirely on water intake volume, are projected for six oncethrough cooled plants, most of the salmon production between Priest Rapids and the power plants would be destroyed. This could be as much as 35 percent of the total salmon production in the Hanford section of the river. Resource loss of this magnitude could not be accepted without good justification. The intake structures for once-through systems should remove water only from the central portion of the river or other locations with low juvenile salmon populations.

If six reactors have once-through cooling, approximately 10 percent of the zooplankton and drift organisms passing the plant intakes would be destroyed or lost to the river. No significant changes in phytoplankton production are expected and there may be some very localized enhancement of benthic productivity in the winter.

Operation of more than ten reactors with once-through cooling probably is unacceptable from an ecological standpoint. At minimum river flows over half the entire river would be diverted through the power plant cooling systems. This would 1) expose over half the entire populations of planktonic and drift organisms and some larval fish to the chemical and mechanical stress of passage through plant cooling systems, and subject the entrained organisms to a temperature rise of $25^{\circ} \mathrm{F}$ or greater; 2) possibly overheat 
the river water locally by recycling the effluents from one cluster of plants through the cluster immediately downstream; and 3) create near-shore increases in temperature that may impede fish migration.

Wet Cooling Towers. Total water intake and blowdown for 40 cooling towers is 1600 and $400 \mathrm{cfs}$, respectively; and the $\Delta t$ of the blowdown is $12^{\circ} \mathrm{F}$. Less than five percent of the minimum river flow would be used for cooling.

No measurable aquatic impacts are envisioned for this case. Off-shore water intake and blowdown discharges should be considered to reduce impingement-entrainment of river organisms in the cooling water system and to reduce exposure of the shoreline areas to undiluted blowdown discharge. The provisions of Public Law 92-500 probably can be met without blowdown treatment. The cases with less than 40 towers would have proportionately smaller impacts.

Cooling Ponds. With proper management ponds could be beneficial for recreational fishing or aquaculture. Very intensive aquaculture of fish produces annual yields up to 1,500 tons/acre (Bardach, 1968). Less intensive management (no supplemental feeding; some fertilization) more appropriate to the cooling pond size and use would produce about 100 to $200 \mathrm{lb} / \mathrm{acre} / \mathrm{yr}$. Care would be necessary to prevent the introduction of radionuclides into the cooling ponds if sport fish or aquaculture is intended.

The creation of cooling ponds may provide new habitat for nuisance algae and fish disease organisms. Prediction of the degree of these undesirable effects is difficult. Much depends upon the kinds of biota that are established in these ponds and the intensity of management. They are not viewed at this time as sources of uncontrollable problems. The necessary cooling ponds for 12 reactors will create about 40,000 acres of new surface water.

The makeup and blowdown water for the worst case of 12 reactors using ponds is only 720 and $180 \mathrm{cfs}$, respectively. No measurable effects on the river aquatic life would be expected from use of that water. 
Aquatic Effects of Specific HNEC Cases. For cases I through V, XI, $X I I$ through XVI and XX (wet towers, wet-dry towers, dry towers), the expected impacts from the withdrawal of river water and the discharge of tower blowdown will be slight and probably imperceptable.

Case VI (once-through, wet towers, cooling ponds) may have an adverse effect on the river organisms, particularly the salmon and trout, during the late summer and early fall (August through October). Approximately 25 percent of the minimum river flow of 36,000 cfs would be heated to a temperature of $25^{\circ} \mathrm{F}$ above ambient. At this minimum river flow the temperature of the river would be raised approximately $6^{\circ} \mathrm{F}$ after complete mixing with the heated condenser discharge. For a fifteen-year minimum seven-day average river discharge of 54,500 cfs, the river temperature would be increased about $4^{\circ} \mathrm{F}$ above ambient. Since river temperatures at this time of year normally approach the upper thermal tolerance limits of salmon and trout, the addition of heat would be expected to have an adverse effect on these fishes. Chinook salmon eggs and larvae exposed in October to $4^{\circ} \mathrm{F}$ above a starting incubation temperature of $56^{\circ} \mathrm{F}$ in laboratory studies shows an increased mortality (Figure 12). The Columbia River thermal maximum of $68^{\circ} \mathrm{F}$ should not be exceeded by the discharge of heated effluents if the anadromous salmonoids in the river are to be protected; and as indicated in the previously cited laboratory study on chinook salmon, this temperature may seasonally be too high for the well-being of these fish.

Case VII (once-through, wet towers, cooling ponds) will withdraw 42 percent of the minimum river flow of $36,000 \mathrm{cfs}$ and about 28 percent of the 15-year, seven-day minimum. The discharge from this complex will raise the river temperature approximately $7^{\circ} \mathrm{F}$ after complete mixing. Both the higher volume of river water withdrawal and the increase in river temperature due to the effluent discharge would be seasonally of environmental concern. The assumed cooling modes for these cases are acceptable only during periods of high river flow and low ambient river temperature.

In cases VIII, IX, X, XVII, XVIII, and XIX (once-through, wet towers, helper towers), 70 to 150 percent of the minimum river flow and 40 to 100 
percent of the 15-year, seven-day minimum flow will be withdrawn. Effluent discharges will increase river temperatures from $7^{\circ} \mathrm{F}$ to $25^{\circ} \mathrm{F}$. Both the high volume of water withdrawn and the large increase in river temperatures make these cases ecologically unacceptable.

\section{Terrestrial Ecological Impacts}

Construction of power plants results in occupancy of land by structures, construction of barriers such as fences and canals, and construction of transmission lines. This alteration of habitat interferes with wildlife movement and causes other ecological impacts.

Impacts of Structures Upon Wildlife. Aerial obstructions can be hazardous to birds, particularly if towers and wires are located on prominent points along major bird migration routes. Wires and towers are especially hazardous during weather conditions that impair visibility. Mortality is caused by collision with the obstruction. Sometimes, raptorial birds that habitually prefer to perch on the tallest structures are electrocuted by short circuiting electrical transmission lines.

Ground obstructions that interfere with the normal movement of animals are fences, canals, and ditches. Chain-link fences six or more feet tall provide effective barriers to mule deer but do not affect smal1 mammals. Medium sized mammals often cross fences by burrowing.

Canals with concrete walls are efficient barriers to almost all land animals. Canals could seriously affect the local movement of mule deer by confining the population between the canal and the Columbia River. Mule deer are good swimmers and they often swim the Columbia River; however, they would not be able to climb steeply-sloped walls of a concrete-lined canal.

Open ditches with steep walls a foot or more in depth and a foot or more wide can obstruct the movement of Great Basin pocket mice and cause mortality. Such ditches are destructive to other animals, such as lizards, snakes, and shrews. 
Habitat Changes Associated with the Development of Cooling Lakes. Pronounced changes in plant communities occur when arid land is inundated with water to form lakes and ponds. Waste ponds on the Hanford Reservation had well-developed shoreline plant communities after 20 years. Vegetation zones consist of aquatic emergent species: cattail and reeds. Permanently moist soils support rank growths of grasses, especially reed canary grass, barnyard grass, rabbitfoot grass, and forbes, especially Russian knapweed, goldenrod, and cudweed. The most aggressive tree species is the peach leaf willow.

Aquatic emergent vegetation provides nesting sites and cover for the red-winged and yellow-headed blackbird, pied-billed grebe, American coot, and ruddy duck. Seeds of aquatic emergent plants provide food for many species of migratory waterfowl and shorebirds. Willow trees provide nest sites for the black-billed magpie, Swainson's hawk, red-tailed hawk, sparrow hawk, great horned owl, northern oriole, and common flicker. Many species of songbirds forage upon insects and seeds associated with shoreline vegetation (Fitzner and Rickard, 1974).

It is clear that the development of ponds and associated vegetational changes would be beneficial to avifauna and also for certain populations of marmals, especially muskrat, mink, meadow mouse, raccoon, skunk, and mule deer.

The animals that would be most deleteriously affected are the species that are adapted to the dry soils and shrub-steppe plant communities. The ancestral range of the Great Basin pocket mouse, grasshopper mouse, blacktailed hare, side-blotched lizard, gopher snake, burrowing owl, and longbilled curlew would be usurped. These kinds of animals would not find the ponds and adjacent habitats acceptable and would have to compete for space with established populations in the adjacent unmodified shrub-steppe habitats or perish.

Maximal populations of Great Basin pocket mice in shrub-steppe vegetation were estimated at about 120 per hectare $(2.2$ acres) (0'Farre11, et 
al., 1975). It can be estimated that usurpation of 40,000 acres of steppe vegetation could result in the demise of habitat supporting two million pocket mice. However, there would still be much habitat available to sustain a large population of mice.

Other animals that would need to find nesting habitat elsewhere are the long-billed curlew and the burrowing owl. The problems of animals adapted to shrub-steppe habitats are not limited to the construction of a nuclear energy center at Hanford, but are compounded by changing land use patterns, especially conversion of steppe vegetation to farm land. New farms destroy vast acreages of suitable steppe habitat each year.

The total loss of ancestral shrub-steppe habitat acreage is recognized as a distinct possibility unless measures are taken to preserve representative acres. To protect and provide a place to study the ecological structure and function of representative shrub-steppe ecosystems, a 75,000 acre tract of land representative of several different kinds of shrub-steppe ecosystems has been established along the western boundary of the Hanford Reservation and is known as the Arid Lands Ecology (ALE) Reserve. The reserve is managed for ERDA by Battelle-Northwest. All vegetation types expected to be affected by the construction of HNEC facilities are represented on the reserve, except for Columbia River riparian communities and certain special biological habitats, such as sand dunes and riverine bluffs.

Habitat Changes Expected from Fenced Exclusion Areas. Tall chainlink fences are expected to interfere with the normal movement patterns of mule deer. Other mammals can cope with chain-link fences as barriers by burrowing beneath the bottom wire. Chain-link fences would not provide a barrier to reptiles or birds.

Site Occupation by Buildings, Parking Lots, Etc. The land occupied by buildings, parking lots, etc. is not available as wildlife habitat and will be lost to biological productivity for an indefinite time period. 
Summarized Effects of Terrestrial Changes. A sumnary of the effects of HNEC facilities on the terrestrial ecology is as follows as given in Table 17.

TABLE 17: Summary of Costs and Benefits Related to Terrestrial Ecology

BENEFITS

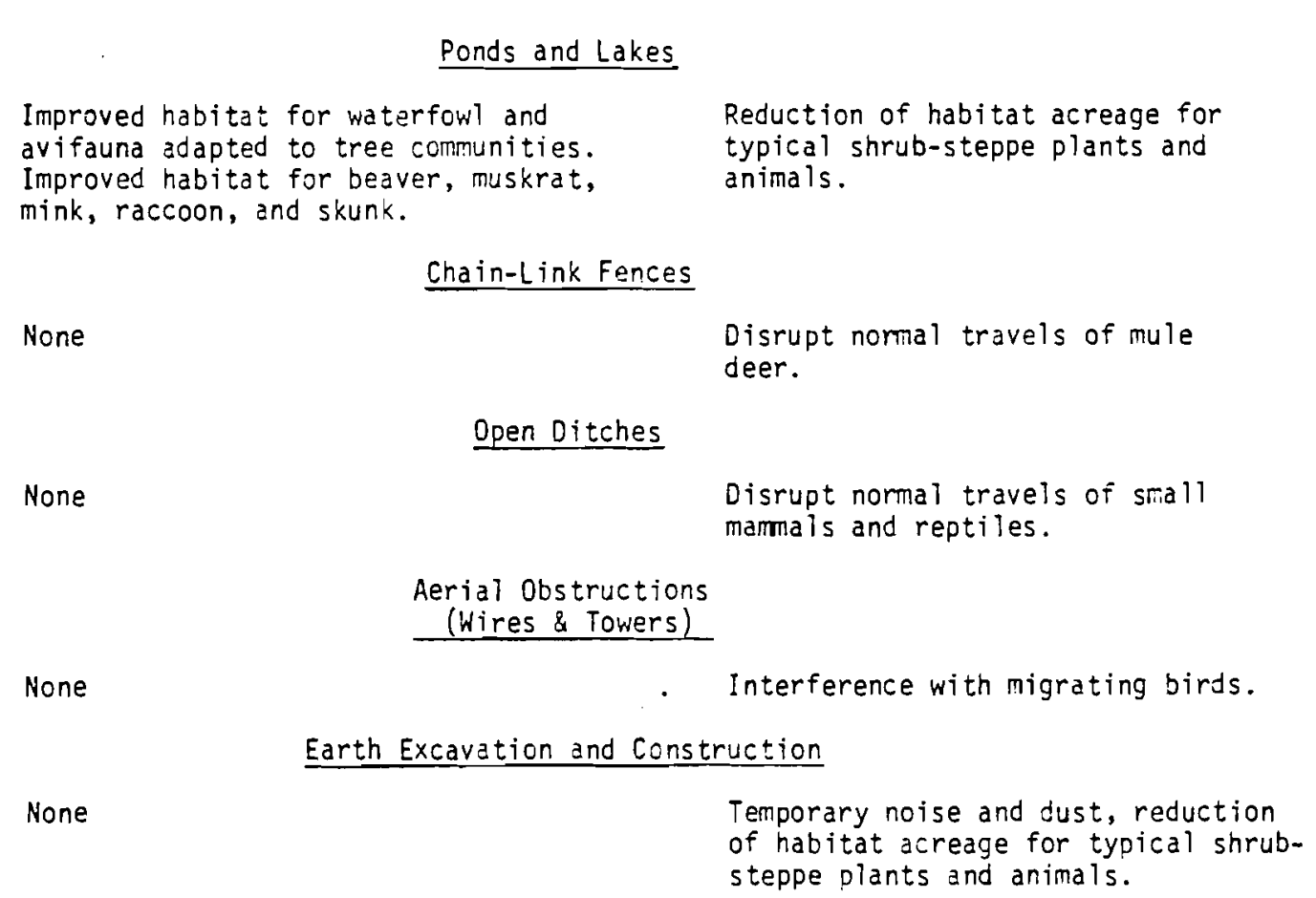

\section{Meteorological Impacts}

The major heat releases and atmospheric effects of energy centers are associated directly with power generation. Atmospheric effects of heat rejection from nuclear energy centers (NRC, 1976) have been postulated on the bas is of theory, models, analogy and speculation. Unfortunately some of the more spectacular effects are primarily the result of the last two processes. Typical effects include: increases in humidity, cloudiness and fog, ground shadowing, enhancement of precipitation and modification of precipitation patterns, triggering of more severe weather types such as thunderstorms, and the concentration of vorticity resulting in the formulation of large dust devils. 
The specific atmospheric effects which might be associated with a particular energy center are generally related to the form of heat rejection, the flux density and area of heat rejection, and the climate of the energy center site. For example, fog and humidity increases are associated with low-level wet cooling systems, and the more specular effects are postulated for closely spaced cooling systems with a high energy flux.

Rational evaluation of the significance of any effect of heat rejection requires that the extent and timing of the effect can be estimated quantitatively, and that significance be defined in meaningful terms. Each of the effects postulated in the Nuclear Energy Center Site Survey (NRC, 1976) report has been considered in a cursory manner to screen out improbable impacts and those which cannot be adequately evaluated at this time.

Concentration of vorticity has been related to high density of the rejected heat and relatively large areas. This was a major concern for the energy centers considered in the Nuclear Energy Center Site Survey where the flux density was about $0.5 \mathrm{~kW} / \mathrm{m}^{2}$. The flux density for the HNEC would be between 0.1 and $0.3 \mathrm{~kW} / \mathrm{m}^{2}$. In addition, there are no simple methods for quantifying the frequency, magnitude or effect of vortices which might be generated. As a result, detailed consideration of vorticity concentration has been postponed until better tools are developed.

Theory and numerical models exist which can provide insight into modification of precipitation patterns and the triggering of storms. As further research is completed, results will be applied to the HNEC. However, recently publicized problems in the National Hail Research Experiment (Science, 1976) raise questions about the reliability of quantitative estimates in this area.

The only atmospheric effects amenable to evaluation at this time are associated with the addition of moisture to atmosphere. In this case the evaluation is only semi-quantitative. Thus, the effect of cooling systems on fog and humidity are the atmospheric impacts used in selection of an overall HNEC heat sink management plan. 
Specific criteria have been identified to determine the significance of changes in the meteorological conditions. These include: a statistically significant change in a meteorological variable, substantial adverse economic impact of a postulated change, initiation of an adverse ecological change, and adverse public reaction. These general criteria provide guidance on the detail required in specification of a postulated impact.

In most cooling system evaluations fog is considered either qualitatively or in terms of additional hours of fog. The impact of an additional hour of fog is indeterminate. If the visibility during that hour is six miles, the impact may be negligible or, at most, psychological. If, on the other hand, the visibility is one-eighth mile or less, the impact can be evaluated in economic terms by considering its effect on transportation and other activities which require greater visibility. In terms of the impact on the public, the use of hours of a given visibility rather than hours of fog is much more meaningful.

Since the impact of fogging had to be estimated in terms of hours of specified visibility, a multiple-source diffusion model was developed in which moisture releases from a variety of cooling systems could be simulated. The large numbers of possible cooling systems and reactor cluster locations were also considered in the model development; i.e., the model had to be economical as well as flexible. The model and its use are described in detail (Ramsde11, 1976). The model is currently equipped to treat moisture releases from the following cooling systems in a rudimentary fashion:

- once-through

- once-through with nelper ponds

- once-through with helper towers

- cooling ponds

- mechanical draft cooling towers

- natural draft cooling towers

- wet-dry cooling towers 
Comparison of the results with the results of other less sophisticated models and actual fog observations indicates that the model is conservative. That is, it tends to predict a greater impact than would be realistically expected if a more detailed treatment had been undertaken.

More than 50 different cases, ranging from a single four reactor cluster near the south side of the reservation to a full 40 reactor energy center, have been examined to evaluate the effects of energy center size, cluster locations and cooling system mix on fog and humidity. As expected, the initial test cases indicated that the most frequently impacted areas outside the energy center would be the Tri-City area of Richland, Kennewick, and Pasco and the region east of the Columbia River and north of Pasco.

A partial compilation of the results of the tests conducted to evaluate the impact of various heat sink management options on fog is presented in Tables 18 and 19. The range of rours of impact in Table 18 for both the 20 and 40 reactor energy centers reflects differences primarily caused by changes in cooling system mixes; differences due to cluster location are secondary. The greatest impact was predicted for those cases with extensive use of cooling ponds and once-through cooling with helper ponds. Lesser impact was predicted for mechanical draft cooling towers and once-through cooling with mechanical draft helper cooling towers, and the least impact was predicted for tall cooling towers and unassisted once-through cooling. It should be noted that where the predicted increase of total hours of fog is less than 40 hours, the predicted increase of hours of visibility less than one-half mile exceeds the increase of total hours of fog.

Three cases with wet-dry mechanical draft cooling towers were examined for both the 20 and 40 reactor energy centers. A11 but four reactors were assumed to use the wet-dry cooling systems. In these cases the fraction of wet cooling varied from $75 \%$ to $25 \%$. The results are given in Table 19 along with the single four-unit cluster ( $0 \%$ wet) and full mechanical draft cooling tower (100\% wet) results. These results indicate the fogging impact of wet-dry cooling system heat rejection at Hanford increases approximately 1 inearly with the wet fraction for both the 20 and 40 reactor centers. 
TABLE 18: Increased Hours of Fog and Visibility Less than One-Half Mile in the Tri-Cities due to an HNEC Using Evaporative Cooling

Case

4 Reactor eluster with Mechanical Draft Cooling Towers

20 Reactor Energy Center

40 Reactor Energy Center

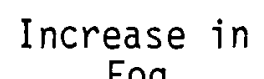

Fog

15

$34-250$

$90-288$
Increase in

Visibility $<1 / 2 \mathrm{mi}$.

28

TABLE 19: Additional Hours of Fog in the Tri-Cities for Energy Centers Using Wet-Dry Mechanical Draft Cooling Towers*.

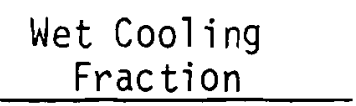

Fraction

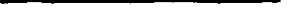

$$
0 \%
$$

$25 \%$

$50 \%$

$75 \%$

$100 \%$

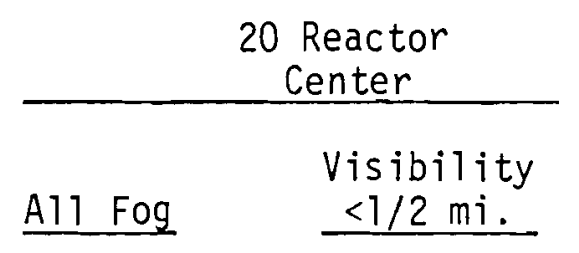

15

37

57

74

98
28

40

52

61

75
40 Reactor Center

\begin{tabular}{|c|c|}
\hline A11 Fog & $\begin{array}{l}\text { Visibility } \\
\leq 1 / 2 \mathrm{mi} .\end{array}$ \\
\hline 15 & 28 \\
\hline 63 & 55 \\
\hline 117 & 86 \\
\hline 164 & 113 \\
\hline 210 & 139 \\
\hline
\end{tabular}

\footnotetext{
* One four reactor cluster is assumed to use conventional mechanical draft cooling towers in each case.
} 
The statistical significance of the postulated increase in total hours of fog and hours of less than one-half mile visibility can be assessed relatively easily using techniques for comparison of mean values. The results of this computation are given in Table 20 as a function of the years of observation following completion of the energy center. An assumed log normal distribution and Hanford fog and visibility statistics were used. The minimum significant increases in the table decrease with increasing observation period, and approach limiting values which are a function of the pre-center climatological fog and visibility records.

TABLE 20: Minimum Statistically Significant Increase in Hours of Fog and Visibility Less than One-Half Mile at the $95 \%$ Significance Level for Hanford

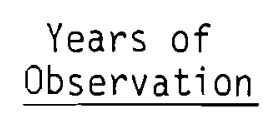

2

4

6

16

36
Change in Hours

of Fog

$101 \cdot 5$

82.9

68.3

$\cdot 45.9$

36.4

26.8
Change in Hours of Visibility

$(<1 / 2 \mathrm{mi}$.

58.2

39.8

32.6

21.7

17.1

$\therefore \quad 12.6$

Since the life of a reactor is generally assumed to be 30 to 40 years, minimum detectable increases will be assumed to be the values given for 36 years of observation. Comparison of these values with predicted impacts given in Tables 18 and 19 shows that the use of evaporative cooling systems may lead to statistically significant impacts on fog and visibility.

The frequency of occurrence of five visibility categories has been estimated for the various cooling system combinations as an initial step in evaluation of the economic impact of moisture releases. Table 21 gives these estimates for current conditions and three cases in which exclusive use of mechanical draft cooling towers was assumed. The visibility categories are directly related to activities which are important to public 
TABLE 21: Predicted Impact of Development of Nuclear Energy Center Using Mechanical Draft Cooling Towers on Fog and Visibility in the Tri-Cities

\begin{tabular}{|c|c|c|c|c|c|c|}
\hline \multirow[t]{2}{*}{$\begin{array}{l}\text { Number of } \\
\text { Reactors } \\
\end{array}$} & \multirow[t]{2}{*}{$\begin{array}{l}\text { Total Hours } \\
\text { of Fog }\end{array}$} & \multicolumn{5}{|c|}{$\begin{array}{c}\text { Hours of Visibility } \\
\text { Less Than Stated Distances } \\
\text { (miles) }\end{array}$} \\
\hline & & $\leq 3$ & $\leq 1$. & $\leq 1 / 2$ & $\leq 1 / 8$ & $\leq 1 / 16$ \\
\hline 0 & 278 & 196 & 132 & 101 & 36 & 8 \\
\hline 4 & 293 & 223 & 162 & 129 & 45 & 12 \\
\hline 20 & 376 & 297 & 221 & 176 & 56 & 16 \\
\hline 40 & 488 & 396 & 300 & 240 & 72 & 22 \\
\hline
\end{tabular}

convenience as well as to changes which can be evaluated in economic terms. An example of the relationship between these categories and the transportation industry is given below.

Reduction of prevailing visibility to less than three miles changes the rules governing airplane flight from visual rules to instrument rules. This has the effect of closing airports to most private pilots, those who are not qualified to conduct instrument flight. In addition to being inconvenient to affected pilots this has a calculable economic effect on local airport and flight service operators. Further reduction of visibility in the Tri-Cities to less than one mile effectively closes the Richland airport to all traffic, including the local commuter airline, Execuair. When visibility becomes less than one-half mile, all air traffic to and from local airports is halted. Surface transportation is impacted as the visibility falls below one-eighth of a mile. Finally when the visibility falls below one-sixteenth mile, surface traffic may be seriously impeded. The impact of reduced visibility on surface traffic can range from delays to an increase in traffic accidents.

These results were obtained using simple atmospheric models in an attempt to optimize heat sink management in a conceptual HNEC. The models are conservative in that they are biased toward overprediction of the impact of cooling system effluents on humidity and fog. Thus the models 
are screening tools to be used to identify subjects for further, more realistic examination. Within this context the following conclusions have been reached:

1) The evaluation of any atmospheric impact postulated for heat dissipation must be conducted in quantitative terms which can be used to determine the significance of the impact.

2) Of the potential atmospheric impacts of large heat releases from energy centers, the one most amenable to quantitative evaluation in meaningful terms at this time is the increase in fog.

3) A postulated increase in frequency of fog can be translated into terms of visibility and both can be evaluated statistically.

4) The translation of a increase in fog to visibility terms permits economic evaluation of the impact.

5) The predicted impact of the HNEC on fog and visibility is statistically significant whether the energy center consists of 20 or 40 units.

Those heat sink management options which cause predicted impacts near the low end of the ranges given in Table 18 are least likely to produce significant impact when examined in more detail. These systems are primarily tall cooling towers, whether natural or mechanical draft, and unassisted once-through systems. Comparison of the predictions in Tabie 19 with the results in Table 20 indicate that extensive use of wet-dry or dry, low mechanical draft cooling towers may reduce the probability of fogging impact to a level consistent with the lower ends of the impact ranges given in Table 18. It should be noted that the single four-reactor cluster is identified as having a potential for reduced visibility during fog, although the impact on total hours of fog is not significant.

\section{Comparison of Alternatives}

The environmental interaction parameters of interest to the comparison of the heat sink alternatives and the evaluation of those parameters are summarized in Table 22 for the 20 reactor HNEC and in Table 23 for the 40 reactor HNEC. 
TABLE 22: Summary Comparison of 20 Reactor Heat Sink Alternatives

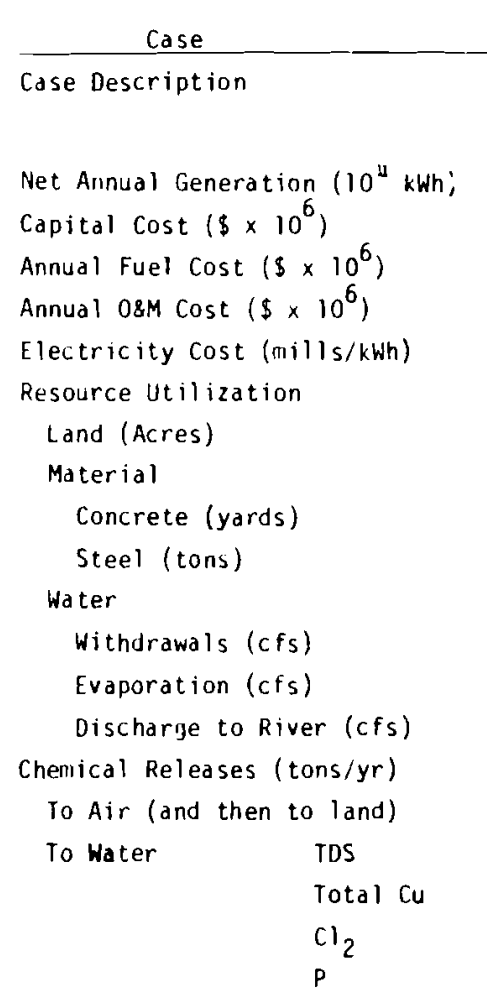

\begin{tabular}{|c|c|}
\hline 1, II & III, IV \\
\hline $\begin{array}{c}\text { Short Wet } \\
\text { Towers }\end{array}$ & $\begin{array}{c}\text { Tall Wet } \\
\text { Towers }\end{array}$ \\
\hline 1.533 & 1.533 \\
\hline 7,200 & 7,240 \\
\hline 632 & 632 \\
\hline 322 & 322 \\
\hline 13.3 & 13.3 \\
\hline 3,200 & 3.200 \\
\hline 720,000 & 800,000 \\
\hline 80,000 & 80,000 \\
\hline 800 & 800 \\
\hline 600 & 600 \\
\hline 200 & 200 \\
\hline 100 & 100 \\
\hline 14,000 & 14,000 \\
\hline 140 & 140 \\
\hline 70 & 70 \\
\hline 140 & 140 \\
\hline
\end{tabular}

$v$
$\begin{array}{r}\text { Wet Dry } \\ \text { Towers }\end{array}$
1.533
7,730
650
337
14.0
3,200
730,000
136,000
400
300
100
50
7,000
70
40
70

$\frac{V I}{\text { Six }}$ and Ponds

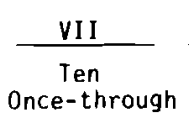

1.533 and Ponds and Towers

$\begin{array}{rr}1.533 & 1.533 \\ 7.080 & 7.010 \\ 624 & 620 \\ 317 & 314 \\ 13.1 & 13.0\end{array}$

21.700

21,700

$\begin{array}{rr}432.000 & 361,000 \\ 74.000 & 71,000\end{array}$

9.700

9,200

15,520

9,200

15,130

35

49,000

120
60

120

20
41,000
110
50
110

$\frac{\text { VIII }}{\text { Ten }}$
IX
Towers

$1.533 \quad 1.533$

7,390

1.533
7.050

624

314

13.0

\section{3,200}

490,000

73.000

15,400

300 *

15,100

50

7,000

70

40
$\frac{X}{\text { Sixteen }} \frac{X I}{\text { Ory }}$

$1.533 \quad 1.533$

$6.930 \quad 8.100$

$\begin{array}{lll}618 & 618 & 670\end{array}$

$322 \quad 310 \quad 347$

$\begin{array}{lll}13.4 & 12.8 & 14.6\end{array}$

$3,200 \quad 3,200 \quad 3,200$

$880,000 \quad 352,000 \quad 737,000$

$120,000 \quad 69,000 \quad 182.000$

$24,200 \quad 24,200 \quad 120$

$500^{\star} \quad 120^{\star} \quad 90$

$23,700 \quad 24,080 \quad 30$

$\begin{array}{rrr}20 & 20 & 15 \\ 3,000 & 3,000 & 0 \\ 30 & 30 & 0 \\ 20 & 20 & 0 \\ 30 & 30 & 0\end{array}$

*Does not include evaporation from river. 

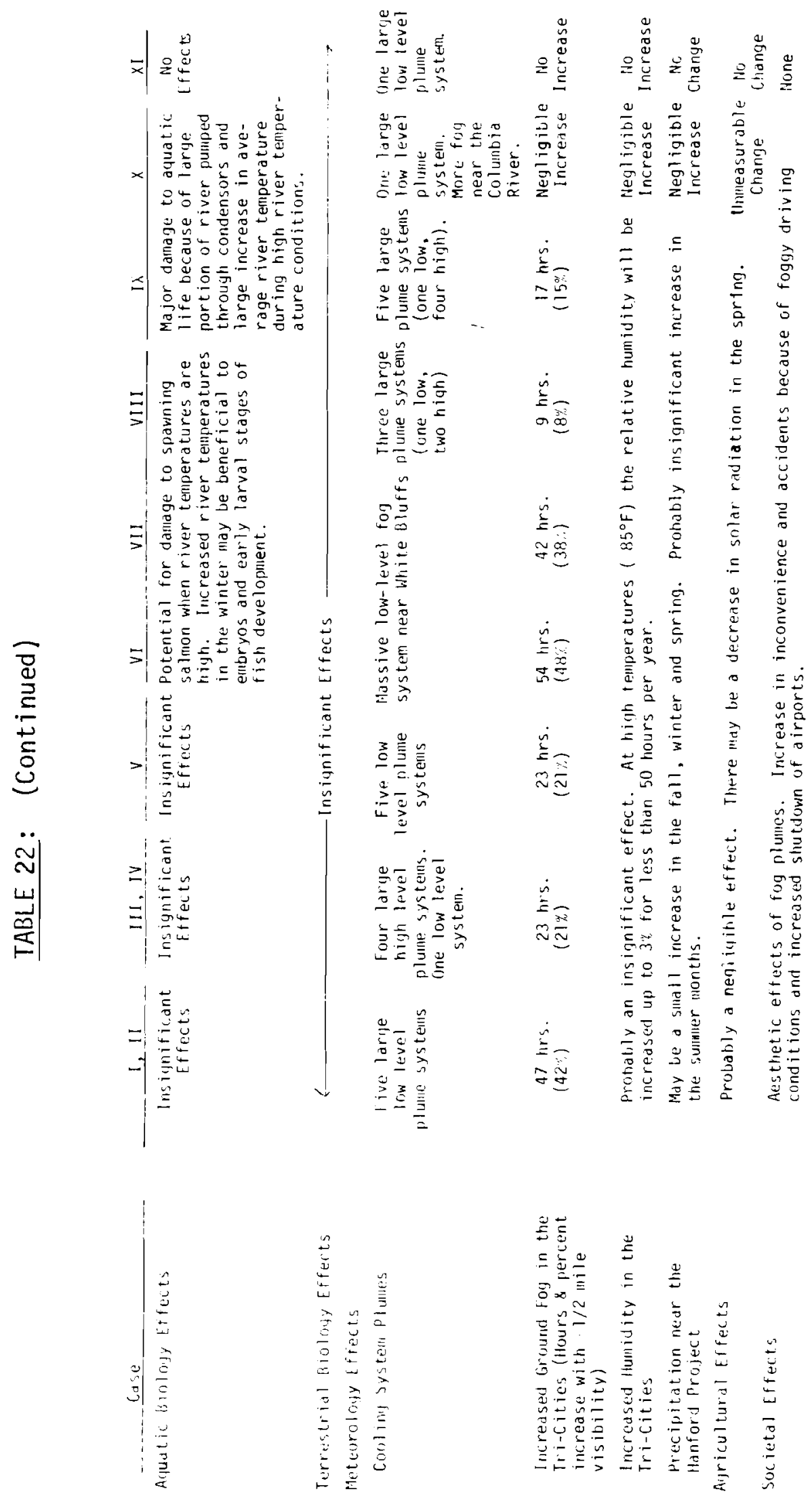
TABLE 23: Summary Comparison of 40 Reactor Heat Sink Alternatives

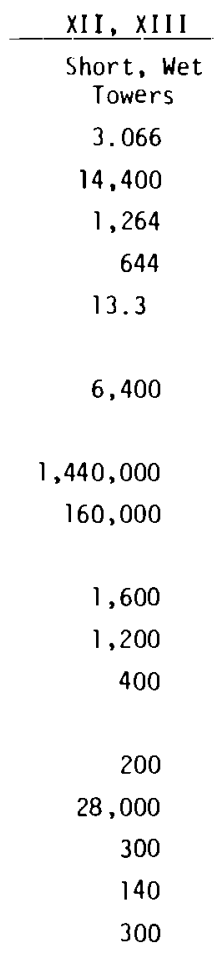

\begin{tabular}{cr} 
XIV, XV & XVI \\
\hline $\begin{array}{c}\text { Tall, Wet } \\
\text { Towers }\end{array}$ & $\begin{array}{r}\text { Wet-Ory } \\
\text { Towers }\end{array}$ \\
3.066 & 3.066 \\
14,500 & 15,500 \\
1.264 & 1,304 \\
644 & 674 \\
13.3 & 14.0 \\
6.400 & 6,400 \\
$1,600,000$ & $1,460,000$ \\
160,000 & 271,000 \\
& \\
1,600 & 900 \\
1,200 & 600 \\
100 & 300 \\
& \\
200 & 100 \\
28,000 & 14,000 \\
300 & 150 \\
140 & 70 \\
300 & 150
\end{tabular}

\begin{tabular}{r} 
XVII \\
\hline Partial \\
Once-throu \\
3.066 \\
13,900 \\
1,238 \\
622 \\
12.9 \\
6,400 \\
888,000 \\
143,200 \\
36,600 \\
$500^{\star}$ \\
36,100 \\
80 \\
11,000 \\
110 \\
50 \\
110
\end{tabular}

\begin{tabular}{r} 
XVIII \\
\hline Hel per \\
3.066 \\
14,800 \\
1,232 \\
644 \\
13.4 \\
6,400 \\
$1,760,000$ \\
240,000 \\
54,200 \\
$1,000^{\star}$ \\
53,200 \\
200 \\
3,000 \\
30 \\
20 \\
30
\end{tabular}

\begin{tabular}{|c|c|}
\hline$x \in X$ & $x x$ \\
\hline $\begin{array}{c}\text { Full } \\
\text { Once-through }\end{array}$ & $\begin{array}{r}\text { Ory } \\
\text { Tower }\end{array}$ \\
\hline 3.066 & 3.066 \\
\hline 13,800 & 16,400 \\
\hline 1,232 & 1,344 \\
\hline 616 & 699 \\
\hline 12.8 & 14.7 \\
\hline 6,400 & 6,400 \\
\hline 612,000 & $1,480,000$ \\
\hline 134,800 & 382.000 \\
\hline$!$ & \\
\hline 54,200 & 120 \\
\hline $120^{\star}$ & 90 \\
\hline 54,080 & 30 \\
\hline 20 & 15 \\
\hline 3,000 & 0 \\
\hline 30 & 0 \\
\hline 20 & 0 \\
\hline 30 & 0 \\
\hline
\end{tabular}

* Does not include evaporation from the river. 


\section{TABLE 23: (Continued)}

\begin{tabular}{|c|c|c|c|c|c|c|c|}
\hline Case & $X I I, X I I I$ & $X I V, X V$ & $X V I$ & XVII & XVIII & $x I X$ & $x x$ \\
\hline Aquatic Biology Effects & $\longleftarrow$ I & Isignificant Effects & $\longrightarrow$ & $\begin{array}{l}\text { Major danage to aqu } \\
\text { portion of river pl } \\
\text { and large increase } \\
\text { ture during high } r\end{array}$ & $\begin{array}{l}\text { uatic life bed } \\
\text { umped through } \\
\text { in average } r \\
\text { iver temperat }\end{array}$ & $\begin{array}{l}\text { cause of large } \\
\text { condensors } \\
\text { iver tempera- } \\
\text { ure conditions. }\end{array}$ & $\begin{array}{l}\text { No } \\
\text { Effects }\end{array}$ \\
\hline Cooling System Plumes & $\begin{array}{l}\text { Ten large low- } \\
\text { level plume } \\
\text { systems }\end{array}$ & $\begin{array}{l}\text { Nine large high- } \\
\text { level \& one large } \\
\text { low-l evel plume } \\
\text { systems }\end{array}$ & $\begin{array}{l}\text { Ten low- } \\
\text { level } \\
\text { plume } \\
\text { systems }\end{array}$ & $\begin{array}{l}\text { Four large } \\
\text { plume systems. } \\
\text { More fog on } \\
\text { Columbia River. }\end{array}$ & $\begin{array}{l}\text { Six large } \\
\text { plume } \\
\text { systems. }\end{array}$ & $\begin{array}{l}\text { One large } \\
\text { low-leve1 } \\
\text { plume system. } \\
\text { More fog on } \\
\text { Columbia River. }\end{array}$ & $\begin{array}{l}\text { One large } \\
\text { low-level } \\
\text { plume system. }\end{array}$ \\
\hline $\begin{array}{l}\text { Increased Ground foy in the } \\
\text { Iri-Cities (Hours } \& \text { percent } \\
\text { increase with } 1 / 2 \text { mile } \\
\text { visibility) }\end{array}$ & $\begin{array}{l}111 \mathrm{hrs} . \\
(99 \%)\end{array}$ & $\begin{array}{l}55 \mathrm{hrs} \\
(49 \%)\end{array}$ & $\begin{array}{l}55 \mathrm{hrs} \\
(49 \%)\end{array}$ & $\begin{array}{l}18 \mathrm{hrs} . \\
(16 \%)\end{array}$ & $\begin{array}{l}42 \mathrm{hrs} . \\
(36 \%)\end{array}$ & $\begin{array}{l}\text { Negl igible } \\
\text { Increase }\end{array}$ & $\begin{array}{l}\text { No } \\
\text { Change }\end{array}$ \\
\hline $\begin{array}{l}\text { Increased Hunidity in the } \\
\text { Iri-Cities }\end{array}$ & \multicolumn{2}{|c|}{$\begin{array}{l}\text { Probably an insignificant effect. } \\
\text { At high temperatures }\left(>85^{\circ} \mathrm{F}\right) \text { the } \\
\text { relative humidity w1li be increased } \\
\text { up to } 6 \% \text { for less than } 50 \text { hours } \\
\text { per year. }\end{array}$} & \multicolumn{3}{|c|}{$\begin{array}{l}\text { Probably an insignif- } \\
\text { icant ef fect. At high } \\
\text { temperature }\left(>85^{\circ} \mathrm{F} \text { ) the }\right. \\
\text { relative humidity will be } \\
\text { increased up to } 3 \% \text { for less } \\
\text { than } 50 \text { hours per year. }\end{array}$} & $\begin{array}{l}\text { Negligible } \\
\text { Change }\end{array}$ & $\begin{array}{l}\text { No } \\
\text { Change }\end{array}$ \\
\hline Agricultural Effects & \multicolumn{6}{|c|}{$\begin{array}{l}\text { Probably a negligible effect. There may be a decrease in solar radiation in the Negligibl } \\
\text { spring. }\end{array}$} & $\begin{array}{l}\text { No } \\
\text { Change }\end{array}$ \\
\hline Societal Effects & \multicolumn{6}{|c|}{$\begin{array}{l}\text { Aesthetic effects of fog plumes. Increase in inconvenience and accidents because of foggy } \\
\text { driving conditions and increased shutdown of airports. }\end{array}$} & None \\
\hline
\end{tabular}


Several simplifying assumptions were used during the preparation of these tables. The primary ones are as follows:

1. A11 economic costs are for 1975 dollars or completion of the construction in 1975.

2. The economic costs for a specific type of heat sink are independent of the plant location (with the restriction that oncethrough and helper systems must be located on the banks of the Columbia River).

3. The Hanford Reservation will continue under U.S. Government or industrial control and there can be no displacement of persons with homesites on those lands.

4. The rate of return on capital is $15 \%$.

5. Helper cooling towers would be the same size as closed-cycle cooling towers and would transfer $72 \%$ of the waste heat to the atmosphere.

6. The intake and discharge structures on the Columbia River are located and designed to produce minimum impact on the aquatic life.

Analysis of the information developed concerning the alternatives leads to several important conclusions concerning the economic and envirormental effects:

1. The differences in economic costs for systems using once-through, pond or wet tower cooling are relatively small (less than $5 \%$ ). However, these cost differences are real because of inherent differences in design. Dry cooling towers cause 10 to $15 \%$ higher power costs than for wet cooling systems.

2. The differences in material usage generally are insignificant for cooling tower systems except for the increase in steel consumption for dry cooling systems.

3. Closed cycle cooling systems have an insignificant aquatic ecology effect.

4. Once-through cooling systems probably will have a major effect on the aquatic life if over 10 reactors have such cooling systems and the average river flow rate is below $54,000 \mathrm{cfs}$.

5. Because of the previous land disturbance and large amount of desert land available, the environmental effects of land use are insignificant except that creation of ponds could improve aquatic habitat. Project ALE will continue to provide an undisturbed large desert research area. 
6. Cooling ponds and short wet cooling towers could cause a noticeable increase in ground fog formation at nearby cities and highways and on the Hanford Reservation.

7. Tal1 wet cooling towers (500 feet tal1) probably would not cause a noticeable change in ground fog formation at nearby cities and highways for construction of up to 20 reactors.

Based on the above information, it is concluded that the best heat sink management system for an HNEC is a mixture of once-through and tall wet tower sysisms containing up to 10 once-through systems. Tall cooling towers appear more desirable than cooling ponds or short cooling towers because of equal economic costs and a much smaller impact due to ground fog formation. Selection of the number of once-through systems will depend on future decisions concerning the minimum flow rates in the Columbia River during the fall and winter periods. The suggested construction of up to 10 once-through systems is based on the assumption that the minimum flow rate will not decrease below the recent fifteen-year minimum, seven-day running average of 54,000 cfs and that enough reactors will be built in the Pacific Northwest so that most, if not a 11, of the reactors with once-through cooling can be shut down for their annual refueling outage during the high river temperature months of August, September, and October. With proper construction and operation of the once-through cooling systems to insure there is minimal effect on spawning salmon, addition of heat to the river during the colder winter months may be beneficial to the salmon population by increasing the growth rate of the young salmon.

Because of uncertainties in both the meteorological and aquatic biology analyses, a cautious approach should be used in scheduling the construction of the HNEC reactors. One strategy might be to defer construction of the once-through cooled reactors until after enough reactors with cooling towers are constructed so that the once-through reactors could be shut down during August to October without causing an electricity or outage personnel shortage. Similarly, the wet cooling towers could be designed such that dry cooling heat exchangers could be added if excessive fog formation occurs. 
In the meantime, two important research studies should be made. Additional aquatic ecology studies should determine the benefits and costs that would result from heating the Columbia River during the various seasons of the year. It is possible that by proper heat additions, the total aquatic ecology could be improved. These studies should include a more accurate determination of the hydro-thermal regions near the intakes and discharges for once-through cooling.

Meteorological research should develop improved methods for estimating the effect of cooling tower operation on fog formation and other meteorological events near an HNEC. Until better analytical methods are available, it may be difficult to select the best cooling systems and convince the surrounding populations that the HNEC is not causing significant adverse effects. 


\section{REFERENCES}

1. Bardach, J. E. and J. H. Ryther, The Status and Potential of Aquaculture Volume II, Particularly Fish Culture, Amer. Instit. Biol. Sci., Washington, D. C., 1968.

2. Becker, C. D., "Feeding Bionomics of Juvenile Chinook Salmon in the Central Columbia River," Northwest Science Volume 44, pp. 75-81, 1970.

3. Becker, C. D. and C. C. Coutant, Experimental Drifts of Juvenile Salmonids through Effluent Discharges at Hanford, Part I. 1968 Drifts, U.S. AEC, R \& D Report, BNWL-1499, Battelle, Pacific Northwest Laboratories, Richland, WA, 1970.

4. Watson, D. G., Fâll Chinook Sallnoin Spawning in the Columbia River near Hanford 1947-1969, ENWL-1515, Battelle Pacific Northwest Laboratories, Richland, WA, 1970.

5. Hatson, D. G., Estimate of Steelhead Trout Spawning in the Hanford Reach of the Columbia River, U.S. Army Corps of Engrs, Contract No. DACN 67-72-C-0100, February 13, 1973.

6. Daubenmire, R., "Steppe Vegetation of Wasinington," Wash. State Agric. Expt. Sta. Tech. Bu11. 62., 131 pp, 1970.

7. Derouin, J. P., memo to P. W. Gottschalk, Production and Waste Management Programs Division AEC from Technical Services Branch, Environmental Safety and Technical Services Division, AEC, January 23, 1972.

8. Jaske, R. T. and H. R. Drew, Simulation of Evaporation from a Cooling Lake with a Comparison to a Real Case and the Alternative Use of Cooling Towers, BNWL-SA-3761, Battelle, Pacific Northwest Laboratories, Richland, WA, March 4, 1971.

9. Final Environmental Statement, Hanford Number Two Nuclear Power Plant, Washington Public Power Supply System, U.S. AEC, Directorate of Licensing, Docket No. 50-397, December 1972.

10. Final Environmental Statement, Waste Management Operations, Hanford Reservation, Richland, Washington, U.S. Energy Research and Development Administration, WASH 1538, Vo1. 2, Ju1y 23, 1975. 
11. Fitzner, R. E. and W. H. Rickard, Avifauna of Westeponds, USAEC Hanford Reservation, Benton County, Washington, BNWL-1885, Batte11e, Pacific Northwest Laboratories, Richland, WA, 1974.

12. Gray, R. H., T. L. Page, E. G. Wolf, and M. J. Schneider, A Study of Fish Impingement and Screen Passage at the Hanford Generating Project A Progress Report, Battelle, Pacific Northwest Laboratories, January 1975.

13. "Häil Suppression up in the Air", Science, Vo1. 191, p. 932, 1976.

14. Hanson, W. C., "Seasonal Patterns of Stable and Radioactive Iodine in Thyroids of Native Jackrabbits," Iwenty-seventh North American Wildlife and Natural Resource Conf., pp. 225-232, 1962.

15. Hanson, W. C. and L. L. Eberhardt, "A Columbia River Canada Goose Population 1950-1970," Wildlife Mono. 28, 61 pp., 1971.

16. Hedlund, J. D., D. T. McCullugh, and W. H. Rickard, "Mouse Population on -Knob and Kettle Topography in South-Central Washington, "Northwest Science, (in press).

17. Hedlund, J. D., "Tagging Mule Deer Fawns in South-Central Washington," Northwest Science, Vol. 49, pp. 153-157, 1975.

18. Jaske, R. T. and M. O. Synoground, Effect of Hanford Plant Operations on the Temperature of the Columbia River, 1964 to Present, BNWL-1354, Battelle, Pacific Northwest Laboratories, November 1970.

19. Laity, W. W., Heat Sink Management for a Hanford Nuclear Energy Center, BNWL-B-448, Battelle, Pacific Northwest Laboratories, November 1975.

20. Langham, G., Ecology of Colonizing Plant Species on Unstable and Stabilized Sand Dunes on the Hanford Reservation, Ph.D. Dissertation, Washington State University, Pullman, WA, 1970.

21. Mains, E. M. and J. M. Smith, The Distribution Size, Time, and Current Preferences of Seaward Migrant Chinook Salmon in the Columbia and Snake Rivers, Wash. Dept. Fish. Res. Papers, Vol. 2, No. 3, March 1964. 
22. Nakatani, R. E., "Effects of Heated Discharges on Anadromous Fishes In Biological Aspects of Thermal Pollution," Proceedings Nat'1. Sympos. on Thermal Pollution, P. A. Krenkel and F. L. Parker, eds. Vanderbilt Univ. Press, 1969.

23. Nuclear Energy Center Site Survey - 1975, Part III Technical Considerations, NUREG-0001, U.S. Nuclear Regulatory Commission, Chapter 3, January 1976.

24. O'Farre11, T. P., R. E. Fitzner, and R. 0. Gilbert, Distribution of Radioactive Jackrabbit Pellets in the Vicinity of the B-C Cribs 200-E Area, USAEC Hanford Reservation, BNWL-1974, Battelle, Pacific Northwest Laboratories, Richland, WA, 1973.

25. O'Farre11, T. P., R. J. 01son, R. O. Gilbert, and J. D. Hedlund, "A Population of Great Basin Pocket Mice, Perognathus parvus, in the Shrub-steppe Region of South-central Washington," Ecol. Monogr., Vol. 45, pp. 1-28, 1975.

26. Page, T. L., R. H. Gray and E. G. Wolf, Reports on Impingement Studies Conducted at the Hanford Generating Project, March and Apri1 1975, Battelle, Pacific Northwest Laboratories, June 1975.

27. Page, T. L., R. H. Gray, E. G. Wolf and M. J. Schneider, Final Report on Ecological Studies Conducted at the Hanford Generating Project, 1973-1974, BNW Report to United Engineers and Construction Inc., Contract 231120135 (In Press), 1976.

23. Park, D. L., "Seasonal Changes in Downstream Migration of Age-Group 0 Chinook Salmon in the Upper Columbia River," Trans. Am. Fish. Soc., Vol. 98, pp. 315-317, 1969.

29. Petterssen, S., Introduction to Meteorology, McGraw Hi1l, New York, 327 pp., 1958.

30. Ramsde11, J. V., Impact of a Hanford Nuclear Energy Center on GroundLevel Fog and Humidity, BNWL-2058, Battelle, Pacific Northwest Laboratories, Richland, WA, 1976. 
31. Rickard, W. H., "Vegetation of Knob and Kettle Topography in Southcentral Washington," Northwest Science, Vo1. 49, pp. 147-152, 1975.

32. Rickard, W. H., J. D. Hedlund, and R. G. Schreckhise, Mammals of the Hanford Reservation in Relation to the Management of Radioactive Waste, BNWL-1877, Batte11e, Pacific Northwest Laboratories, Richland, WA, 1974.

33. Schreiber, C. L., C. D. Becker, and J. J. Fuquay, Appraisal of Water Intake Systems on the Central Columbia River, BNW Report to Burns and Roe, Inc. for the Washington Public Power Supply System, (Purchase Order No. BR-2808-7), March 1973.

34. Schreiber, R. K., Bioenergetics of Rodents in the Northern Great Basin Desert, Ph.D. Dissertation, University of Idaho, Moscow, ID, 1973.

35. Stone, W. A., D. E. Jenne, and J. M. Thorp, Climatography of the Hanford Area, BNWL-1605, Battelle, Pacific Northwest Laboratories, Richland, WA, 1972. 
APPENDIX A

TERRESTRIAL ECOLOGY SPECIES 
TERRESTRIAL ECOLOGY SPECIES

IMPORTANT VASCULAR PLANTS OF THE SAGEBRUSH-BITTERBRUSH/CHEATGRASS COMMUUNITY

Common Name

SHRUBS

Big sagebrush

+Antelope bitterbrush

Nauseosus rabbitbrush

Yellow rabbitbrush

Spiny hopsage

Snow eriogonum

Prickly pear cactus
Scientific Name

Artemisia tridentata

Purshia tridentata

Chrysothamnus nauseosus

Chrysothamnus viscidiflorus

Grayia spinosa

Eriogonum niveum

Opuntia poiyacantha

PERENNIAL GRASSES

Sandberg bluegrass

†Needle-and-thread grass

Thickspike wheatgrass

Indian ricegrass

PERENNIAL FORBS

Pale evening pririrose

Carey balsamroot

Longleaf phlox

Scurf pea

Yarrow

Sego 1 ily

Cluster lily

Turpentine parsley

Sand dock

ANNUALS

* Spring draba

* Jagged chickweed

Tansy mustard

*Tumbl eweed

*Tumble mustard

$+\star$ Cheatgrass

Sixweek's fescue

Microsteris

Phacelia

Polemonium

Plectritis

Bursage

*Alien species

Important livestock forage

+ Important wildlife forage

Poa sandbergi $i$

Stipa comata

Agropyron dasystachyum

Oryzopsis hymenoides

Denothera paliida

Balsamorhiza careyana

Phlox longifolia

Psoralea lanceolata

Achillea millifolium

Calochortus macrocarpus

Brodiaea douglasii

Cymopterus terebinthinus

Rumex venosus

Draba verna

Holos teum umbel latum

Descurainia pinnata

Salsola kali

Sisymbrium altissimum

Bromus tectorum

Festuca octoflora

Microsteris gracil is

Phacelia linearis

Polemonium micrantha

Plectritis macrocera

Franseria acanthicarpa 
BIRDS UTILIZING POND HABITATS

(Modified from Fitzner and Rickard, 1975)

ORDER PODICIPEDIFORMES

Family Podicipedidae

Horned Grebe

Eared Grebe

Western Grebe

Pied-billed Grebe
Podiceps auritus Podiceps caspicus Aechmophorus occidental is Podilymbus podiceps

\section{ORDER CICONI IFORMES}

Fami 1y Ardeidae

Great Blue Heron Black-crowned Night Heron

American Bittern

Ardea herodias

Nycticorax nycticorax Botaurus Tentiginosus

\section{ORDER ANSERIFORMES}

Family Anatidae

Whistling Swan

Canada Goose

Mallard

Gadwa 11

Pintail

Green-winged Tea 1

Blue-winged Teal

Cinnamon Tea1

American Wigeon

Shoveler

Redhead

Ring-necked Duck

Canvasback

Greater Scaup

Lesser Scaup

Common Goldeneye

Barrows Goldeneye

Bufflehead

01d Squaw

Ruddy Duck

Hooded Merganser

Common Merganser
Olor columbianus

Branta canadensis

Anas platyrhynchos

Anas strepera

Anas acuta

Anas crecca carolinensis

Anas discors

Anas cyanoptera

Anas americana

Anas clypeata

Aythya americana

Aythya collaris

Aythya valisineria

Aythya marila

Aythya affinis

Bucephala clangula

Bucephala islandica

Bucephala albeola

Clangula hyemal is

Oxyura jamaicensis

Lophodytes cucullatus

Mergus merganser 
ORDER GRUIFORMES

Fami ly Gruidae

Sandhi11 Crane

Family Rallidae

Sora

American Coot

ORDER CHARADRI IFORMES

Family Charadriidae

Killdeer

Family Scolopacidae

Common Snipe

Long-billed Curlew

Spotted Sandpiper

Greater Yellowlegs

Lesser Yellowlegs

Pectoral Sandpiper

Least Sandpiper

Dunl in

Long-billed Dowitcher

Western Sandpiper

Sanderling

Family Recurvirostridae

American Avocet

Family Phalaropodidae

Wilson's Phalarope

Northern Phalarope

Family Laridae

California Gull

Ring-billed Gul 1

Bonaparte's Gull
Grus canadensis

Porzana carolina

Fulica americana

Charadrius vociferus

Capella gall inago Numenius americanus Actitis macularia Tringa flavipes Totanus flavipes Calidris melanotos Calidris minutilla Erolia alpina Limnodromus scolopaceus Ercunetes mauri Crocethia alba

Recurvirostra americana

Steganopus tricolor Lobipes lobatus

Larus californicus Larus delawarensis Larus philadelphia

ORDER CORACIIFORMES

Family Alcedinidae Belted Kingfisher 
ORDER FALCONIFORMES

Family Accipitridae

Sharp-shinned Hawk
Red-tailed Hawk
Swainson's Hawk
Golden Eagle
Marsh Hawk

Family Falconidae

Sparrow Hawk
Accipiter striatus Buteo jamaicensis Buteo swainsoni Aguila chrysaetos Circus cyaneus

Falco sparverius

ORDER STRIGIFORMES

Family Strigidae

Great Horned Ow1

Bubo virginianus

Burrowing Ow1 Speotyto cunicularia

UPLAND GAME BIRDS

ORDER GALLIFORMES

Family Phasianidae

California Quail

Ring-necked Pheasant

Chukar

Lophortyx cal ifornicus Phasianus colchicus Alectoris chukar

ORDER COLUMBIFORMES

Family Columbidae

Rock Dove

Mourning Dove

Columba livia

Zenaida macroura 
BIRDS ASSOCIATED WITH TREES AND OTHER RIPARIAN

VEGETATION AROUND WASTE PONDS

ORDER PIDIFORMES

Family Picidae

Red-shafted Flicker

Lewis' Woodpecker

Hairy Woodpecker

Downy Woodpecker
Colaptes auratus

Asyndesmus lewis

Dendrocopos villosus

Dendrocopos pubescens

ORDER PASSERIFORMES

Family Tyrannidae

Eastern Kingbird

Western Kingbird

Ash-throated Flycatcher

Say's Phoebe

Western Wood Peewee

Family Alaudidae

Horned Lark

Family Corvidae

Black-billed Magpie

Common Raven

Common Crow

Family Sittidae

Red-breasted Nuthatch

Family Troglodytidae

Winter Wren

Long-billed Marsh Wren

Canon Wren

Famil y Mimidae

Mockingbird

Sage Thrasher
Tyrannus tyrannus

Tyrannus verticalis

Myiarchus cinerascens

Sayornis saya

Gontopus sordidulus

Eremophila alpestris

Pica pica

Corvus corax

Corvus brachyrhynchos

Sitta canadensis

Troglodytes troglodytes Telmatodytes palustris Catherpes mexicanus

Mimus polyglottos Oreoscoptes montanus 
ORDER PASSERIFORMES (Cont.)

Family Turdidae

Robin
Varied Thrush
Hermit Thrush
Western Bluebird
Townsend's Sol itaire

Family Sylviidae

Golden-crowned Kinglet Ruby-crowned Kinglet

Family Motacillidae

Water Pipit

Family Laniidae

Loggerhead Shrike

Family Sturnidae

Starling

Family Vireonidae

Hutton's Vireo

Red-eyed Vireo

Warbling Vireo

Family Parulidae

Orange-crowned Warbler Nashville Warbler

Yellow Warbler

Yellow-rumped Warbler

Townsend's Warbler MacGillivray's Harbler Wilson's Warbler

Family Ploceidae

House Sparrow
Turdus migratorius Ixoreus naevius Hylocichla guttata Sialia mexicana Myadestes townsend $i$

Regulus satrapa Regulus calendula

Anthus spinoletta

Lanius ludovicianus

Sturnus vulgaris

Vireo huttoni

Vireo olivaceus

vireo gilvus

Vermivora celata Vermivora ruficapilla Dendroica petechia Dendroica coronata Dendroica townsendi Oporornis tolmiei Wilsonia pusilla

Passer domesticus 
ORDER PASSERIFORMES (Cont.)

Family Icteridae

Western Meadowlark Yellow-headed Blackbird

Red-winged Blackbird

Northern Oriole

Brewer's Blackbird

Brown-headed Cowbird

Family Thraupidae

Western Tanager

Piranga ludoviciana

Family Fringillidae

House Finch

American Goldfinch

Rufous-sided Towhee

Savannah Sparrow

Lark Sparrow

Sage Sparrow

Darkeyed Junco

Tree Sparrow

White-crowned Sparrow

Golden-crowned Sparrow

Swamp Sparrow

Song Sparrow

Sturne11a neglecta

Xanthocephalus xanthocephalus

Agelaius phoeniceus

Icterus galbula

Euphagus cyanocephalus

Molothrus ater

Carpodacus mexicanus

Spinus tristis

Pipilo erythrophthalmus

Passerculus sandwichens is

Chondestes grammacus

Amphispiza belli

Junco hyemalis

Spizella arborea

Zonotrichia leucophrys

Zonotrichia atricapilla

Melospiza georgiana

Melospiza melodia

BIRDS THAT FEED ON FLYING INSECTS

ORDER CAPRIMULGIFORMES

Family Caprimulgidae

Common Nighthawk

Chordeiles minor

ORDER PASSERIFORMES

Family Hirundinidae

Barn Swallow

Cliff Swallow

Hirundo rustica

Petrochelidon pyrrbonota 
MAMMALS

Great Basin Pocket Mouse

Deer Mouse

Harvest Mouse

House Mouse

Grasshopper Mouse

Sagebrush Vole

Cottontai1

Blacktailed Hare

Mule Deer

Townsend Ground Squirrel

Pocket Gopher

Cyote

Bobcat

Badger

Raccoon

Beaver

Muskrat

Mink

Weasel

Skunk
Perognathus parvus

Peromyscus maniculatus

Reithrodontomys megalotis

Mus musculus

Onychomys Leucogaster

Lagivus curtatus

Sylvilagus nutta $11 i$

Lepus californicus

OdocoiTeus hemionus

Spermophilis townsendii

Thomomys talpoides

Canis latrans

Lynx rufus

Taxidea taxus

Procyon lator

Castor canadensis

Ondatra zibethica

Mustela vison

Mustela frenata

Mephitis mephitis

SNAKES AND LIZARDS

Pacific Rattlesnake

Gopher Snake

Side-blotched Lizard

Fence Lizard

Horned Lizard
Crotalus viridis

Pituophis melanoleucus

Uta stansburiana

Sceloporus graciosus

Phrynosoma douglasii

VASCULAR PLANTS OF MOIST HABITATS

Cattai1

Reed Canary Grass

Rabbitfoot Grass

Cudweed

Bulrush

Wiregrass

Peachleaf Willow

Barnyard Grass

Russian Knapweed

Wild Onion
Typha latifolia

Phalaris arundinacea

Polypogon monspielensis

Onaphalium margaritacea

Scirpus

Eleocharis

Sal ix amygda loides

Echinochloa crus-galli

Centurea repens

Allium sibericum 
BNWL-2003

UC-80

\section{$\underline{\text { DISTRIBUTION }}$}

No. of

Copies

\section{OFFSITE}

1 ERDA Chicago Patent Group

A. A. Churm

1 Aluminum Company of America

Post Office Box 120

Vancouver, WA 98660

Lyman J. Harris

Northwest Area Power Manager

1 Benton County Public Utility

District

Post Office Box 6273

Kennewick, WA 99336

Robert W. Blodgett

Manager

1 Bonneville Power Administration Post Office Box 3627

Portland, OR 97208

C. Ray Foleen

Deputy Administrator

1 Culp, Dwyer, Guterson and Grader 1300 Hodge Building Seattle, WA 98104

Gordon Culp

1 Electric Power Research Institute Post Office Box 10412

Palo Alto, CA 94304

Laura Henning

20 Energy Research and Development

Administration

Mail Stop F-309

Washington, DC 20545

Theodore Beresovski

Chief, Advanced Concepts
No. of

Copies

27 ERDA Technical Information Center

1 Nuclear Regulatory Commission Washington, DC 20555

1 Pacific Northwest Utilities Conference Committee Post Office Box 1231 Wenatchee, WA 98801

Howard C. Elmore Cha irman

1 Pacific Northwest Utilities Conference Committee on Engineering and Planning 2730 Northwest 77 th Place Portland, OR 97213

David J. Lewis Consultant

1 Portland General Electric Company 621 Southwest A1der Street Portland, OR 97205

A. J. Porter Vice President

1 Puget Sound Power and Light Company Puget Power Building Post Office Box 535 Bellevue, WA 98004

John W. Ellis

President

1 Springfield Utility Board 250 N. "A" Street

Box 300

Springfield, OR 97477

Jack Criswell

General Manager 
No. of

No. of

Copies

Copies

OFFSITE

1 National Academy of Public

Administration

1225 Conn. Avenue NW

Washington, DC 20036

R. Kloman

2 Washington State Energy Office

1000 South Cherry

Olympia, WA 98504

Keith Sherman

2 Oregon Department of Energy

528 Cottage Street NE

Salem, OR 97310

W. Kelly Woods

15 Energy Facility Site Evaluation

Council

820 E. Fifth Avenue

01 ympia, WA 98504

Roger Polzin

D. B. Cearlock

D. W. Dragnich

E. A. Eschbach

S. J. Farmer

J. W. Finnigan

R. F. Foster

J. C. Fox

R. C. Free

J. J. Fuquay

H. Harty (25)

A. J. Haverfield

L. D. Kannberg

J. W. Litchfield

D. E. Olesen

L. T. Pedersen

J. V. Ramsdel1

W. H. Rickard

L. C. Schmid

C. L. Simpson

B. E. Vaughan

D. G. Watson

J. R. Young

Technical Information (5)

Technical Publications (3)

\section{ONSITE}

8 ERDA Richland Operations Office

0. J. Elgert

P. W. Gottschalk

R. H. Lindsey/G. L. Liffick

F. R. Standerfer

M. W. Tiernan

Research and Development Programs Division

W. A. Burns (2)

59 Battelle-Nor thwest

F. W. Albaugh

T. W. Ambrose

R: G. Baca

A. Brandstetter

N. E. Carter 